\author{
STRUKTURA I FINANSE GMINY ORMIAŃSKIEJ WE LWOWIE \\ W ŚWIETLE RĘKOPISU „DZIEJE ORMIAN LWOWSKICH OD R. 1649 - \\ AŻ DO R. 1713" (OSSOLINEUM NR 1646/II)
}

\title{
Uwagi ogólne
}

Przedmiotem artykułu jest analiza treści rękopisu napisanego w języku polskim, znajdującego się w zbiorach Zakładu Narodowego im. Ossolińskich we Wrocławiu, zatytułowanego „Dzieje Ormian lwowskich od r. 1649 - aż do r. 1713”. Rękopis pochodzi z drugiej połowy XVII i początku XVIII wieku i zawiera akta i uchwały lwowskiej rady starszych ormiańskich, jak również kwity, rozliczenia, inwentarze, rejestry i inne dokumenty związane ze społecznością ormiańską we Lwowie w XVII i początkach XVIII wieku. Rękopis znajduje się w Ossolineum pod sygnaturą 1646/II i opatrzony jest opisem „Zawiera akta i uchwały gminy ormiańskiej we Lwowie z lat 1647-1713”. Data powstania jest określona w opisie bibliotecznym na lata 1651-1750. Rękopis został zdigitalizowany i umieszczony w Dolnośląskiej Bibliotece Cyfrowej (http://www.dbc.wroc.pl) i ta kopia elektroniczna została wykorzystana do napisania artykułu. Według informacji zamieszczonej w katalogu Ossolineum rękopis jest dostępny również w formie zmikrofilmowanej w Bibliotece Narodowej.

„Dzieje Ormian lwowskich od r. 1649 - aż do r. 1713” nie są jedynym rękopisem związanym ze lwowską społecznością ormiańską przechowywanym w Ossolineum. Sam rękopis powstał we Lwowie i prawdopodobnie tam się znajdował od czasu powstania aż do końca II wojny światowej, gdy został przewieziony na zachód i znalazł się w zbiorach Ossolineum we Wrocławiu. Sadok Barącz podaje w swoich pracach z połowy XIX wieku, że rękopis, cytowany przez niego pod tytułem „Dzieje Ormian lwowskich ab Anno 1649 ad 1713”, znajdo- 
wał się w księgozbiorze kapituły ormiańskiej lwowskiej. Można przypuszczać, że w późniejszym okresie rękopis trafił do kolekcji lwowskiego Ossolineum, by przy powojennym podziale zbiorów trafić na tereny obecnej Polski i w końcu do Wrocławia. Niestety trudno jest w tym miejscu podać więcej faktów na ten temat.

Z pewnością rękopis był znany wielu badaczom przeszłości Ormian w Polsce, począwszy od samego Barącza i jego prac Żywoty stawnych Ormian w Polsce oraz Rys dziejów ormiańskich. Barącz posługiwał się jednak tym źródłem wybiórczo, wyciągając $\mathrm{z}$ niego tylko pojedyncze informacje, mające poprzeć stawiane przez niego tezy. Przykładowo na potwierdzenie twierdzenia o tym, że Dominik Bogdanowicz był najbogatszym kupcem w ówczesnym Lwowie, podał zaczerpnięty z rękopisu fakt, że kwota przekazana przezeń na okup dla Szwedów w 1704 roku wyniosła 7000 talarów. Późniejsi, XX-wieczni badacze, tacy jak Łucja Charewiczowa, korzystali z prac Barącza, powtarzając podawane przez niego informacje. Przed wojną fakt istnienia omawianego rękopisu musiał być więc ogólnie znany i prawdopodobnie był on dostępny dla zainteresowanych historyków. Nie wydaje się jednak, żeby źródło to było kiedykolwiek dogłębnie zbadane. Ponadto rękopis, pomimo że zawiera ciekawe i cenne dane do badań nad społecznością ormiańską w Polsce, nie został nigdy wydany drukiem. W XXI wieku niektóre fragmenty źródła były wykorzystywane w pracach polskich armenologów i historyków, jednak wciąż nie doczekało się ono szerszej analizy.

Niestety z racji zdalnego dostępu do badanego rękopisu niemożliwe jest w tym miejscu przedstawienie wyczerpującego jego opisu zewnętrznego. Rękopis ma format folio. W skromnej informacji katalogowej Ossolineum podano, że liczy 278 stron. Jest oprawiony w formie kodeksu, a stron, na których pojawia się jakikolwiek tekst, jest łącznie 232, co daje 46 stron pustych. Na przedniej wyklejce znajduje się numer inwentarzowy 1646, jak również dwa wklejone urywki kart, prawdopodobnie $\mathrm{z}$ innych części rękopisu. W księdze znajduje się paginacja, prawdopodobnie wpisana $\mathrm{w}$ późniejszym okresie niż powstanie rękopisu, która numeruje strony od 1 do 278 , zarówno zapisane, jak i puste. $Z$ liczby paginowanych stron można wnioskować, że na tej podstawie powstał opis katalogowy w Ossolineum. Oprócz tego na początku i na końcu dokumentu znajduje się jeszcze kilka stron nienumerowanych i pustych, a na trzeciej nienumerowanej stronie wpisany jest - prawdopodobnie tą samą ręką, która dokonała paginacji - tytuł „Dzieje Ormian lwowskich od r. 1649 - aż do r. 1713”. Pierwotnie rękopis nie miał więc tytułu i został on dodany podczas inwentaryzacji. Na kartach księgi znajduje się także foliacja od 1 do 86, wpisana inną ręką niż paginacja. Liczba folio nie sumuje się w 278 stron i może świadczyć o połączeniu w jednym kodeksie kilku rękopisów. Foliacją nie objęto ostatniej części rękopisu, od s. 206. Wszystkie numerowane strony rękopisu są ręcznie obramowane, przy czym nie wszędzie pisarz lub pisarze pracowali na tyle starannie, by zmieścić się w prostokącie wyznaczonym obramowaniem strony. Pisarze użyli atramentu o różnych odcieniach czerni i brązu, o ile można stwierdzić na podstawie kopii elektronicznej księgi. 
Rękopis pod względem charakteru pisma oraz treści można podzielić na trzy części. W pierwszej, obejmującej strony 1-139, znajdują się uporządkowane chronologicznie akta i uchwały rady starszych ormiańskich we Lwowie z lat 1649-1667. Druga część obejmuje strony 141-203 i stanowi dość luźny zbiór dokumentów, rozliczeń i rejestrów wpisywanych w nieuporządkowany sposób i zamykających się pod względem dat widniejących przy dokumentach w zakresie lat 1647-1713. Trzecia część to strony 204-278 zawierające dwa krótkie i jeden długi inwentarz przedmiotów stanowiących części majątku Kościoła ormiańskiego we Lwowie. Inwentarze z trzeciej części pochodzą z lat 1681, 1687 i 1693.

Pod względem uporządkowania i staranności pisma pierwsza i trzecia część rękopisu wyraźnie odcinają się od drugiej. W pierwszej części, mającej charakter czystopisu, znajdują się bardzo wyraźnie i czytelnie wpisane i uszeregowane chronologicznie odpisy dokumentów rady starszych ormiańskich miasta Lwowa z lat 1649-1667. Oryginały tych pism powstały najprawdopodobniej na posiedzeniach (,sesyiach”) rady starszych odbywających się w ich „residentiey uprzywilegiowaney" (s. 93). Dokumenty w tej części podzielono według lat, a każdy rok jest poprzedzony „Regestrem” dokumentów z danego roku, umieszczonym zazwyczaj na osobnej stronie. Same rejestry są wpisane innym charakterem pisma niż reszta dokumentów w tej części i prawdopodobnie wpisała je inna osoba albo ta sama osoba, ale w późniejszym okresie. Można tak wnioskować z faktu, że niektóre rejestry zostały wpisane na osobnej stronie, a niektóre pod tekstem dokumentów na tej samej stronie. Gdyby jedna osoba od razu dzieliła dokumenty rejestrami, prawdopodobnie wszystkie znalazłyby się na osobnych stronach.

Liczba dokumentów w pierwszej części w poszczególnych latach waha się od 4 do 15, przy czym dwukrotnie połączono dwa lata w jeden rejestr (1654-1655 oraz 1656-1657). Trudno powiedzieć, czy są to wszystkie dokumenty z danego roku wpisywane podczas posiedzeń rady starszych ormiańskich, ale ze względu na ich małą liczbę można domniemywać, że nie. Być może księga zawiera jedynie wybór dokumentów dokonany według nieznanego obecnie klucza. Tezę o braku niektórych dokumentów wspiera znajdujące się na s. 19 pismo z 20 kwietnia 1651 roku, które wymienia $\mathrm{w}$ treści inny akt z 9 marca tego samego roku, którego jednak nie znajdujemy w rękopisie.

Łączna liczba dokumentów wpisanych w pierwszej części rękopisu wynosi 130, co jak na okres 18 lat nie wydaje się wielką liczbą. $Z$ drugiej strony inne dokumenty mogły być wpisywane do innych ksiąg, z których akurat nie korzystał pisarz przepisujący je na czysto.

Trzecia część źródła, czyli inwentarze, jest wpisana tą samą ręką co część pierwsza (z wyjątkiem rejestrów dokumentów). Charakter inwentarzy, a zwłaszcza głównego inwentarza katedry ormiańskiej we Lwowie z 1687 roku, wymógł na pisarzu układ $\mathrm{w}$ formie list kolejnych typów przedmiotów, takich jak: relikwiarze, kielichy, lichtarze, szaty liturgiczne. Te listy przedmiotów są wpisane równie starannie co dokumenty z części pierwszej, z wykorzystaniem prostokąt- 
nego obramowania stron. Pomiędzy kolejnymi typami przedmiotów jest wiele niezapisanego miejsca, a nawet całe puste strony, tak jakby pisarz chciał zostawić miejsce na dopisanie kolejnych przedmiotów.

Druga, środkowa część źródła jest zbiorem nieuporządkowanym i niestarannym i wydaje się, że zawarte w niej dokumenty musiały być wpisywane szybko. Jednak to w tej części zawarto najistotniejsze z punktu widzenia niniejszego artykułu dokumenty. Obramowanie stron nie jest tu przeważnie respektowane, wpisy są zazwyczaj niewyraźne, pokreślone, wpisane krzywo itd. Dokumenty nie są wpisane w porządku chronologicznym. Wydaje się, że wpisów dokonała więcej niż jedna osoba, co potwierdza zróżnicowany charakter pisma, nawet na pojedynczych stronach (na przykład s. 171). Można przypuszczać, że wpisów w tej części dokonały co najmniej dwie osoby. Tę grupę dokumentów można ogólnie podzielić pod względem treści na: 1. rejestry zadłużenia w obrębie gminy ormiańskiej lwowskiej, 2. dokumenty dotyczące koekwacji po opłaceniu okupu dla Bohdana Chmielnickiego i Tuhaj beja w 1648 roku, 3. dokumenty dotyczące opłacenia kontrybucji dla Szwedów w 1704 roku, 4. inne. Zakres chronologiczny treści tej części rękopisu jest najszerszy spośród wszystkich trzech i obejmuje lata 16141713. W tej części pojawia się najwięcej kwot pieniężnych i list osób mogących posłużyć za cenne dane do badań z zakresu demografii historycznej gminy ormiańskiej we Lwowie. Liczbę rejestrów, bilansów, spisów itp. z tej części można określić na około 20, jednak mimo pozornie małej liczby dokumentów danych do wykorzystania jest dużo, gdyż niektóre z wpisów zajmują po kilka stron księgi.

Już po tym krótkim przedstawieniu zawartości omawianego źródła można stwierdzić, że tytuł wpisany podczas inwentaryzacji „Dzieje Ormian lwowskich od r. 1649 - aż do r. 1713" nie jest do końca precyzyjny, gdyż najwcześniejsze pisma pochodzą z roku 1647. Końcowa data zgadza się zaś z tytułem - najpóźniejsze dokumenty są z 1713 roku. Chronologia treści źródła jest natomiast jeszcze szersza, bo kopie najwcześniejszych dokumentów z 1647 roku dotyczą bilansów sięgających wstecz aż do roku 1614. Można więc stwierdzić, że zasięg chronologiczny treści całego źródła pokrywa się z zakresem części drugiej i dotyczy okresu prawie stu lat, od 1614 do 1713 roku. Źródło nie dotyka jednak wszystkich lat $\mathrm{z}$ tego okresu w równie szczegółowy sposób, koncentrując się na niektórych podokresach, a zupełnie pomijając inne.

Przy próbie ustalenia czasu powstania źródła, to jest czasu wpisywania do niego kolejnych dokumentów, w pierwszej kolejności trzeba zwrócić uwagę na fakt, że zawarte w rękopisie dokumenty, rozliczenia itd. nie są oryginałami, lecz odpisami, a większą część zbioru można traktować jako rodzaj kopiariusza, mającego na celu zebranie ważnych z punktu widzenia lwowskiej społeczności ormiańskiej pism. Fakt, że pierwsza część rękopisu jest wpisana starannie, bez skreśleń i jedną ręką, to tylko jedna z przesłanek pozwalających przypuszczać, że mamy do czynienia z kopiariuszem. Oprócz tego w treści pierwszej i drugiej części źródła jest kilka dowodów na to, że dokumenty zawarte w rękopisie są odpisa- 
mi oryginałów. Na s. 96 w końcowej części dokumentu wpisano sformułowanie „(Miesce Krzyżyka)”, co sugeruje, że w tym miejscu w oryginale znajdował się krzyżyk w charakterze podpisu, postawiony przez zainteresowaną osobę. Podobnie na s. 115 znajdujemy uwagę „(Locus Sigilli)” sugerującą, że w tym miejscu w oryginalnym dokumencie znajdowała się pieczęć, w tym wypadku arcybiskupa ormiańskiego Mikołaja Torosowicza. Kolejnym dowodem na wpisywanie kopii do omawianego rękopisu jest uwaga pisarza na s. 201: „bo ten billans tylko dla J.W. Im. Pana Stemboka generała woysk szwedzkich wystawiony był et eodem tempore przekopiowany do tych xiąk". Do tego cała lista podpisów pod jednym $\mathrm{z}$ rejestrów jest wpisana jedną ręką (s. 191-192), a pisarz posługuje się przy tym skrótami, na przykład: „Popis Żydowski pięć wirszóf totes pięć person starych Żydóf”, co można interpretować jako „pięć wierszy z podpisami pięciu Żydów [starszych?]" (bez wymieniania imion). Na kolejnej stronie znajdujemy podobny wpis: „Po szwedzku sześć wirszów”. Być może pisarz-kopista nie był w stanie przepisać zawartości dokumentu w obcych językach i dlatego zastosował powyższe opisy.

Kwestia kopiowania dokumentów komplikuje próbę ustalenia czasu powstania źródła, ponieważ nawet jeśli dokument zawiera w nagłówku datę dzienną, trudno ustalić, kiedy dokładnie został wpisany do rękopisu. Są tylko nieliczne wskazówki pozwalające na ustalenie czasu powstania części rękopisu. Jedną z nich jest przytoczony powyżej fragment ze s. 201: „,bo ten billans [...] wystawiony był et eodem tempore przekopiowany do tych xiąk". Eodem tempore oznacza w tym wypadku rok 1704, gdy Lwów został zajęty przez Szwedów. Tę uwagę można rozszerzyć na szereg innych dokumentów dotyczących tego wydarzenia, zwłaszcza kontrybucji dla Szwedów.

By móc zawęzić przypuszczalny zakres chronologiczny powstania rękopisu, należy jeszcze przyjrzeć się możliwym autorom wpisów. Niestety żaden z pisarzy lub kopistów nie podał informacji o sobie ani się nie podpisał. Na kartach rękopisu pojawiają się nazwiska pisarzy, ale trudno ich zidentyfikować jako kopistów ze względu na duży odstęp czasowy (na przykład na s. $161 \mathrm{w}$ rejestrze koekwacji z 1653 roku pojawia się p. pisarz Iwaszkowicz). W źródle znajduje się natomiast kilka dopisków, które z pewnością nie są skopiowane, a pochodzą od samego pisarza bądź pisarzy. W kilku miejscach pisarz (pisarze) ubolewa nad upadkiem finansowym nacji ormiańskiej we Lwowie, porównując sytuację zastaną w kopiowanych dokumentach z rzeczywistością w jego czasach (na przykład s. 155,165$)$.

Pomimo że wpisów w rękopisie dokonała więcej niż jedna osoba, wydaje się, że znaczna jego część wyszła spod ręki jednego pisarza. Po pierwsze początkowa i ostatnia część, jak wspomniano wyżej, jest pisana tą samą ręką; po drugie nie można wykluczyć, że któreś z niestarannie wpisywanych dokumentów z części środkowej pochodzą od tego samego pisarza, który zapisał na czysto część pierwszą i trzecią. W inwentarzu katedry ormiańskiej znajduje się notatka, która 
może stanowić podparcie dla takiej tezy. Pod opisem cennych przedmiotów znajdujących się w żamatunie (budynku przylegającym do katedry) widnieje późniejszy dopisek z roku 1713 głoszący, że „to zabrali Szwedzi” i pisany podobnym charakterem pisma, chociaż mniej starannie niż inwentarz pochodzący z roku 1687. Można więc z dużą dozą ostrożności przyjąć, że ten sam pisarz, który sporządził inwentarz, po 26 latach dopisał stratę. W takiej sytuacji można by również założyć, że ten sam pisarz mógł być przynajmniej autorem wpisów dotyczących kontrybucji dla Szwedów w 1704 roku. Do potwierdzenia tej tezy potrzebna by jednak była pogłębiona analiza grafologiczna.

Do uwag o kopiowaniu pism i możliwej liczbie pisarzy należy jeszcze dodać, że inwentarze z części trzeciej, zwłaszcza długi inwentarz katedry, były raczej wpisywane $\mathrm{z}$ autopsji niż odpisywane $\mathrm{z}$ innych inwentarzy. To przypuszczenie oraz fakt, że inwentarze wpisane są tą samą ręką co dokumenty z części pierwszej, pozwalają na hipotetyczne odtworzenie procesu powstawania rękopisu. Pod koniec XVII wieku pisarz wpisywał inwentarze z tyłu kodeksu, a na początku przepisywał na czysto dokumenty gminy od roku 1649. Prawdopodobny zamysł był taki, żeby kontynuować przepisywanie dokumentów na czysto, o czym świadczy obramowanie wszystkich stron rękopisu. Pisarz doszedł jednak tylko do roku 1667; być może dalszą pracę przerwały działania wojenne, zwłaszcza zdobycie Lwowa przez Szwedów. Wtedy jeden lub więcej pisarzy skopiowali do środkowej, wolnej części księgi dokumenty o kontrybucji szwedzkiej, jak również inne, dotyczące wcześniejszego okresu. W zmienionych warunkach dokumenty kopiowano już naprędce i niestarannie. Jeden z pisarzy z pewnością dokonał części wpisów w 1713 roku, o czym świadczą jego dopiski, w których celowo zawarł roczną identyfikację powstania wpisu, na przykład ,teraz in A[nno] 1713" (s. 165).

Podsumowując dywagacje o czasie powstania rękopisu i jego autorach: wydaje się, że możliwe jest określenie czasu powstania rękopisu w przybliżeniu na lata 1681-1713, a autorstwo większości wpisów można przypisać jednej osobie.

W jakim celu mogła powstać omawiana księga-kopiariusz? Trudno odpowiedzieć na pytanie, czy pisarz lub pisarze działali na zlecenie, czy też z własnej inicjatywy, choć bardziej prawdopodobna wydaje się ta pierwsza możliwość, gdyż pisarze ormiańscy byli zatrudniani przez gminę. Można podejrzewać, że celem przepisywania dokumentów było ich utrwalenie w drugiej kopii, jak również zebranie $\mathrm{w}$ jednej księdze dokumentów z różnych źródeł, a mających istotne znaczenie dla społeczności ormiańskiej we Lwowie. Przede wszystkim wszelkie rozliczenia, bilanse, kwity itp. mogły służyć za dowód w sprawach sądowych i w innego typu sporach, a także stanowić źródło wiedzy o przeszłości finansowej gminy ormiańskiej dla kogoś, kto przepisywał dokumenty kilkadziesiąt lat później. $Z$ pewnością pisarzom, a zwłaszcza ich zleceniodawcom, mogło zależeć na tym, by wiedza o dawnych wierzytelnościach nie uległa zapomnieniu. W przypadku dokumentów kopiowanych na bieżąco, czyli tych związanych 
z kontrybucją dla Szwedów w 1704 roku, chodziło zapewne o utrwalenie dowodów rozliczenia nacji ormiańskiej z miastem i z okupantem, jak również uregulowanie należności wśród samych Ormian. Zaś inwentarze z części trzeciej rękopisu powstały w dość oczywistym celu spisania przedmiotów znajdujących się w „skarbcu kościoła naszego ormiańskiego mieyckiego lwowskiego”.

Językiem rękopisu jest polski, z pojedynczymi słowami łacińskimi i ormiańskimi. Okres powstania oryginałów większości dokumentów zawartych w księdze (druga połowa XVII wieku) jest jednocześnie okresem ostatecznego porzucenia przez Ormian w Polsce języka kipczackiego na rzecz polskiego. W aktach z końca XVII i początku XVIII wieku nie znajdziemy już dokumentów po kipczacku. Pojawia się jednak pytanie: czy któreś ze wcześniejszych pism nie są przypadkiem tłumaczeniami kipczackich oryginałów? We wcześniejszym okresie we Lwowie Ormianie często tłumaczyli swoje dokumenty na polski, żeby były zrozumiałe na przykład dla władz miejskich. Ponieważ jednak najwcześniejsze pod względem czasu powstania dokumenty zawarte w księdze pochodzą z $1647 \mathrm{roku}$, można raczej założyć, że ich oryginalnym językiem był polski. Łyżką dziegciu w tej beczce miodu może być sformułowanie przed jednym ze spisów na s. 156: „Copia tego regestru z originału orm. p. Krzysztof Zachnowicz wystosował”. Ormianie lwowscy pod pojęciem ,język ormiański”, czyli swój własny, rozumieli często właśnie kipczacki. Taka uwaga nie jest jednak wystarczającym dowodem dla hipotezy o wpisywaniu do księgi tłumaczeń zamiast oryginalnych pism.

\section{Struktura i finanse gminy ormiańskiej we Lwowie na podstawie części pierwszej rękopisu}

\section{KLASYFIKACJA DOKUMENTÓW Z CZĘŚCI PIERWSZEJ RĘKOPISU}

Na podstawie części pierwszej rękopisu można przynajmniej w pewnej części odtworzyć strukturę i funkcjonowanie gminy ormiańskiej we Lwowie w drugiej połowie XVII wieku, jak również poznać niektóre $\mathrm{z}$ dręczących tę gminę problemów.

Przy okazji warto zwrócić uwagę, że słowo „gmina” nie pojawia się na kartach rękopisu, natomiast w odniesieniu do społeczności ormiańskiej we Lwowie jest szeroko stosowane pojęcie „natia” (nacja, dokładnie „Natia Ormian Miescka Lwowska”, s. 29). Termin ,gmina ormiańska” jest zaś terminem stosowanym przez historyków po II wojnie światowej w pracach dotyczących ,grup etniczno-religijno-prawnych" w miastach Polski średniowiecznej i nowożytnej, a więc między innymi Ormian. Słowa „nacja” w tym kontekście używali jednak jeszcze historycy przedwojenni ${ }^{1}$. Moim zdaniem zarówno określenie „gmina”, jak i „,nacja" jest tu właściwe, o ile wiadomo dokładnie, o czym mowa.

${ }^{1} \mathrm{~Np}$. Ł. Charewiczowa, Ograniczenia gospodarcze nacyj schizmatyckich i żydów we Lwowie XV i XVI wieku, Lwów 1925. 
Jak już zaznaczono w części pierwszej, dokumenty z części pierwszej zamykają się w ramach chronologicznych lat 1649-1667, a więc około 18 lat. Nie da się stwierdzić bez porównania z innym źródłem, czy są to wszystkie dokumenty $\mathrm{z}$ tego okresu. Ze względu na małą liczbę pism jest to jednak, jak już wcześniej zaznaczono, raczej wątpliwe. W zbiorze 130 wpisanych dokumentów można wyodrębnić następujące kategorie (uszeregowane według liczby wystąpień):

\begin{tabular}{|l|c|}
\hline \multicolumn{1}{|c|}{ Kategoria dokumentów } & Liczba \\
\hline Kwity, rozliczenia, sprawozdania & 38 \\
\hline Akty wyboru urzędników gminnych & 15 \\
\hline Uchwalenie składek & 13 \\
\hline Sprawy związane z Kościołem ormiańskim & 8 \\
\hline Wybór deputatów & 7 \\
\hline Listy osobowe starszych ormiańskich & 6 \\
\hline Uchwały rady starszych inne niż składki & 6 \\
\hline Wybór nowych członków rady starszych & 6 \\
\hline Rekomendacje do prawa miejskiego & 6 \\
\hline Omówienie z pospólstwem spraw związanych z funkcjonowaniem gminy & 5 \\
\hline Przyjęcie do bractwa i/lub pospólstwa ormiańskiego & 4 \\
\hline Sprawy spadkowe & 4 \\
\hline Admonicje & 2 \\
\hline Pozwolenia & 2 \\
\hline Rezygnacje & 2 \\
\hline Protestacja & 1 \\
\hline Rozsądzenie sporu o prowadzenie szynku & 1 \\
\hline Spis przedmiotów & 1 \\
\hline Sprawy małżeńskie & 1 \\
\hline Wybór reprezentacji pospólstwa & 1 \\
\hline Wybór nauczyciela i bakałarza & 1 \\
\hline Łącznie & 130 \\
\hline
\end{tabular}

Tabela 1. Dokumenty w części pierwszej rękopisu

Powyższa klasyfikacja jest oparta z jednej strony na tytułach dokumentów zawartych w księdze, $\mathrm{z}$ drugiej - na analizie ich treści. Kolejne wpisy w części pierwszej rękopisu poprzedzają bądź wyróżniające tytuły pism, na przykład „Uchwała № 4 składek die 29 May”, bądź mniej wyróżniające, konwencjonalne tytuły, brzmiące zazwyczaj: „Działo się w residentiey zacnie sław. pp. starszych sądów Orm. lwows. die 17 Octobris”, „Działo się w residentiey zacnie sławnych pp. starszych praw Ormian lwow. die 25 Febr.”, „Actum w residentiey die 8 Marty" itp. Tytułom dokumentów towarzyszy zwykle data dzienna, a każdy zbiór pism z danego roku jest opatrzony datą roczną, wpisywaną zazwyczaj na początku grupy dokumentów. 
Przedstawiona wyżej klasyfikacja pokazuje, że charakter pism w pierwszej części rękopisu jest bardzo różnorodny, ale dominują sprawy finansowe. Do księgi, którą kopiował pisarz do omawianego rękopisu, wpisywano jednak wszystkie dokumenty w kolejności chronologicznej, bez podziału na kategorie. Mieszają się tu sprawy finansowe z administracyjnymi, prawnymi, kościelnymi itd. Wynika stąd, że posiedzenia („sesyie”) rady starszych miały charakter wielofunkcyjny i omawiano na nich bieżące sprawy gminy.

\section{STRUKTURA GMINY}

\section{Urzędnicy gminni}

Zbiory pism z kolejnych lat otwierają często, choć nie zawsze, akty wyborów urzędników gminnych. Najczęściej dokumenty te są datowane na luty bądź marzec, z czego można wnioskować, że urzędników wybierano zazwyczaj na początku roku. Być może to wtedy odbywało się pierwsze posiedzenie rady starszych w danym roku. Okres kadencji urzędników trwał standardowo jeden rok: „którzy podług zwyczaiu urzędy swe maią odprawować a po wyściu roku złożyć" (s. 79). Była jednak przewidziana możliwość przedłużenia kadencji urzędniczej na kolejny rok: „unanimi consensu obrali z pośrodku siebie per electionem pp. erecpochanów pierwszego p. Krzysztopha Awedik Bernatowicza a drugiego pa. Krzysztopha Awedik Zachnowica którzy na swych urzędach do roku tylko residować maią. A inszych na urzędach będących na miescach swych zostawili y reasumowali" (s. 87). W 2 (na 15) przypadkach wybór urzędników odbył się w innych miesiącach niż luty i marzec: raz w czerwcu i raz w lipcu. Chodziło jednak nie o wybór wszystkich urzędników na dany rok, lecz jedynie po dwóch, prawdopodobnie na wakujące stanowiska (s. 99, 102).

\section{Rada starszych}

Oprócz urzędów z kadencją roczną istniały też urzędy tymczasowe oraz urząd w założeniu dożywotni: członkostwo w radzie starszych. Tzw. starszeństwo było bez wątpienia najważniejszą funkcją w ormiańskiej gminie we Lwowie. W omawianym rękopisie członkowie rady starszych występują jako „panowie starsi”,2, a sama rada funkcjonuje pod nazwą collegium (s. 50). Z tego też powodu starsi używają w stosunku do siebie zwrotu collega (s. 109). W analizowanych dokumentach rada starszych ma stałą liczbę członków - 12, co wynika ze spisów osobowych rady („Numerus PP. Starszych”), pojawiających się najczęściej po aktach wyborów nowych jej członków. Starsi mieli bardzo szerokie kompetencje, od zarządców majątku gminnego i kościelnego do sędziów prawa ormiańskiego

\footnotetext{
${ }^{2}$ Najpełniejsza nazwa występująca w omawianym źródle to „zacnie sławni pp. starsi praw Ormian lwowskich przysięgli” (s. 1 i dalej).
} 
(ich oficjalna nazwa zmieniła się w drugiej połowie XVII wieku ze starszych na sędziów ${ }^{3}$, s. 141, 143).

Udział w radzie starszych był dożywotni, jednak można było ją opuścić z powodu nobilitacji, co wiązało się z dobrowolną rezygnacją ze starszeństwa. Takie rezygnacje są w omawianym rękopisie dwie: w 1655 roku Jan Warteresowicz, najbogatszy kupiec ormiański, przedłożył radzie, „iż on ex statu civili iest promotus ad statum nobilitatis od JKMPNMo y RzeczyPospolity Koronney, a że daley in collegio pp. starszych zostawać iusz niemoże" (s. 50). Do podobnej sytuacji doszło w 1659 roku, gdy również bardzo bogaty kupiec Iwaszko Torosowicz zrezygnował ze starszeństwa (s. 71). Najwyraźniej uzyskanie szlachectwa było czymś wysoce pożądanym, skoro pragnęli tego najbogatsi spośród Ormian, a po rezygnacji Iwaszka pozostali starsi powinszowali mu uzyskania „statu nobilitatis".

Oczywiście po rezygnacji jednego ze starszych pozostali członkowie rady musieli dobrać spośród pospólstwa nowego „kolegę” na jego miejsce. Częstszą przyczyną konieczności wyboru nowego członka rady była jednak nie rezygnacja, lecz śmierć poprzednika: ,pp. starsi [...] według starodawnych zwyczaiów zgodnym y iednostaynym consensem obrali z między pp. pospolitych na starszęnstwo na miesce nbczka [nieboszczyka] pa. Iwaszka Stephanowica, sławet. pana Krzysztofa Zadikiewicza, którego praesentowawszy pospólstwu do akt regiminis zapisać rozkazano" (s. 35). Z tego aktu wyboru na „starszeństwo" można wyciągnąć wniosek, że wszyscy członkowie rady starszych byli kiedyś „pospolitymi”, a więc w pospólstwie istniała, przynajmniej teoretyczna, droga awansu.

\section{Pospólstwo}

Pospólstwo, pojawiające się na kartach rękopisu równie często co rada starszych, nie zostało nigdzie w rękopisie szczegółowo zdefiniowane. Ta grupa występuje również pod nazwą ,pospolici” (s. 1) oraz communitas (s. 102). Prawdopodobnie chodzi tu o Ormian nienależących do rady starszych, lecz posiadających obywatelstwo miejskie ormiańskie ${ }^{4}$. Wielu z nich, co wynika między innymi z treści omawianego rękopisu, posiadało też nieruchomości w mieście. Z grupy sześciu dokumentów z kategorii „rekomendacje do prawa miejskiego" możemy wyczytać, jak wyglądała procedura przyjmowania nowych członków nacji ormiańskiej, a więc ,pospolitych”. Rada starszych musiała w pierwszej kolejności przychylić się do prośby petenta o objęcie go prawem ormiańskim, a następnie „zalecić” daną osobę do otrzymania prawa miejskiego, czyli zwrócić się

${ }^{3}$ M. Kapral, Armenian and Ruthenian elders in Lviv in the late medieval and early modern period: their emergence, functions and interaction, w: Armenian-Ukrainian historical contacts, Lviv 2011, s. 32.

${ }^{4}$ Informacja prof. Krzysztofa Stopki. 
z prośbą do władz miejskich o przyjęcie nowego obywatela. Taka inkorporacja wiązała się oczywiście ze stosowną opłatą i niejednokrotnie była związana także z przyjęciem do bractwa religijnego (s. 137).

Możliwe, iż pospólstwo ormiańskie rozumiane jako Ormianie posiadacze obywatelstwa miejskiego było na tyle nieliczne, że istniała możliwość zebrania przez radę starszych całego pospólstwa w jednym miejscu, na przykład w celu konsultacji bądź przeprowadzenia wyboru deputatów. Jednak takie zebrania były najwyraźniej trudne do przeprowadzenia, o czym świadczy uchwała rady starszych z 1652 roku o wyborze piętnastoosobowej reprezentacji pospólstwa, ,a to dla częstey absentiey ich, którzy szukaiąc pożywienia swego tak tu w mieście, iako y extra w kraiach odległych muszą zdobywać y nie bydź obecnymi” (s. 30). Nie wiadomo tylko, czy udało się radzie starszych uzyskać zezwolenie królewskie na utworzenie takiego kolegium spośród pospólstwa, a z pewnością było ono konieczne: ,a po tym tego postanowienia approbatią od Króla Jmści otrzymać starać się mamy" (s. 32). Owa piętnastoosobowa reprezentacja pospólstwa nie pojawia się już na kartach rękopisu i nie wiadomo, czy ten pomysł w ogóle wszedł w życie.

Wydaje się, że pospólstwo było rodzajem przeciwwagi dla rady starszych, gdyż ta druga nie tylko oznajmiała pospólstwu swoje decyzje, lecz także konsultowała się z nim, głównie w kwestiach związanych ze zbieraniem składek. Pospólstwo miało przynajmniej możliwość wyrażenia swojego zdania, więc nie było wyłącznie milczącym uczestnikiem procesu zarządzania gminą. Relacje i wzajemne zależności pomiędzy pospólstwem i radą starszych są z pewnością materiałem na osobny artykuł.

Ponieważ do pospólstwa nikogo nie wybierano, a o przynależności świadczył jedynie status prawny i cenzus majątkowy, wydaje się, że - w przeciwieństwie do członkostwa w radzie starszych - członkostwa w pospólstwie nie można traktować jako urzędu gminnego. Zresztą członkostwo w radzie również nie jest nigdzie nazwane wprost urzędem i z pewnością było dla Ormian czymś odmiennym niż urzędy wybierane corocznie bądź urzędy tymczasowe.

\section{Urzędy $z$ kadencją roczną}

Na urzędy z kadencją roczną starsi wybierali urzędników spośród siebie (por. wyżej cytowany fragment: „obrali z pośrodku siebie per electionem”, s. 87). Wyboru dokonywali obecni starsi jednogłośnie, czyli unanimi consensu, ,iednostaynym consensem". Ponieważ wszystko odbywało się w rzadko zmieniającej się grupie 12 członków rady starszych, na przestrzeni omawianych 18 lat w listach urzędników pojawiają się ciągle te same osoby. Jedna osoba mogła pełnić kilka urzędów jednocześnie (na przykład s. 17) i mogła być wybierana na to samo stanowisko przez wiele lat z rzędu. 
Od zasady wyboru urzędników spośród samych starszych zdarzały się odstępstwa; istnieją przypadki wyboru na urzędy osób spośród pospólstwa ${ }^{5}$. Być może taka konieczność wynikała $\mathrm{z}$ nieobecności niektórych starszych w mieście, co było nagminnym problemem z racji kupieckiej profesji Ormian (z rady i z pospólstwa) i jest uwidocznione również w wyżej przedstawionej próbie powołania piętnastoosobowej reprezentacji pospólstwa. Urzędników wybierano zazwyczaj parami, po dwóch do każdej funkcji, jednak i od tej reguły są wyjątki - zdarzało się, że na tę samą funkcję wybierano trzy lub nawet cztery osoby (s. 52), prawdopodobnie zgodnie $\mathrm{z}$ aktualnymi potrzebami administracyjnymi. Tytuły dokumentów wyboru urzędników gminnych brzmią podobnie: „Act electiey pp. erecpochanów y innych urzędników na tęn rok obranych”, „Electia pp. urzędników na tęn rok obranych". Dzięki tym aktom elekcji możemy wyróżnić poszczególne urzędy w gminie ormiańskiej we Lwowie. Nazwy tych funkcji nie były raz na zawsze ustalone, dlatego występują w różnych formach.

W pierwszej kolejności zawsze wymieniani są „,panowie erecpochani” (erecpochanowie, jeriespochani). Ta funkcja, z podziałem na „pierwszego” i „drugiego" 6 erecpochana, była pełniona często (choć nie zawsze) przez wpływowe i bogate osoby. Dość powiedzieć, że wieloletnim erecpochanem był Krzysztof Awedik Bernatowicz, jeden z najbogatszych kupców nie tylko wśród Ormian, lecz także w całym Lwowie ${ }^{7}$. Ormiańskie słowo kpłuuhnłuui (jerespochan) oznacza dosłownie pełnomocnika, namiestnika lub deputata; powstało z połączenia słów kpliu (jeres - osoba, twarz) i łhnjuui (pochan - zamiast, w miejsce) ${ }^{8}$. Być może pierwotnie chodziło o zastępców wójta w rozmaitych sprawach. W omawianym okresie gmina ormiańska we Lwowie od dawna nie miała już jednak własnego wójta ${ }^{9}$. Nazwę „erecpochan” można więc dla tego okresu interpretować bardziej jako „pełnomocnik, przedstawiciel, zarządca z ramienia gminy”. Oprócz dwóch głównych erecpochanów wybierano też erecpochanów do zadań szczegółowych.

W tym miejscu można się zastanowić, czy kolejność wyboru, przez większość lat taka sama, był ustalona według pozycji prestiżowej urzędów (od najważniejszego do mniej ważnego). Nie jest to nigdzie stwierdzone wprost, jednak ciągłe pojawianie się na pierwszym miejscu erecpochanów „głównych”, którymi często byli, jak wspomniano, najbogatsi członkowie gminy, może dać do myślenia.

Po dwóch erecpochanach „głównych” rada wybierała „panów od pieczęci”. Po pieczętarzach następował przeważnie wybór ,„panów erecpochanów od skar-

5 Na przykład: „Dnia dzisieyszego zasiadszy pp. starsi w residentiey swey obrali zgodnie prowizorów szpitalnych. Jednego z collegij swey szlachetnego p. Mikołaia Steckiewicza, a drugiego ex communitate sławet. p. Łazarza Mathiaszowica” (s. 94).

${ }^{6} \mathrm{Z}$ rękopisu nie wynika, czym różnili się ,pierwszy” i „drugi” erecpochan, można przypuszczać, że w grę wchodziły kwestie prestiżowe.

7 S. Barącz, Żywoty sławnych Ormian w Polsce, Lwów 1856, s. 71.

${ }^{8}$ M. Bedrossian, New Dictionary: Armenian-English, Venice 1875-1879.

9 O. Balzer, Sądownictwo ormiańskie w średniowiecznym Lwowie, Lwów 1909, s. 41. 
bu kościelnego". W wyniku wytworzonej w ciągu stuleci sytuacji majątek Kościoła ormiańskiego we Lwowie pozostawał pod zarządem świeckiej gminy ${ }^{10}$, stąd zapotrzebowanie na tego typu urzędników. Być może to z woli tych erecpochanów pilnujących skarbu (bądź skarbca) kościelnego zapadła decyzja o stworzeniu inwentarzy rzeczy ruchomych ze skarbca katedry ormiańskiej, zawartych w trzeciej części omawianego rękopisu. Chodziło tu jednak nie tylko o zarząd majątkiem ruchomym i nieruchomym, lecz także o obsługę zadłużenia na tymże majątku. Te sprawy były na tyle poważne, że niekiedy łączono urząd erecpochanów „głównych” i „od skarbu kościelnego”. Na przykład w akcie wyboru urzędników na rok 1665 na s. 110 pod wierszem „pp. do skarbu kościelnego” wyszczególniono „pp. jerespochani obadwa” (w tym wypadku byli to Krzysztof A. Bernatowicz i Krzysztof A. Zachnowicz), a jako trzeciego wybrano Jana Krzysztofowicza. Być może to o tych erecpochanach jest mowa w dokumencie z 1665 roku, który głosi, że „Revizia skarbu kościelnego odprawiła się przez szlachet. pp. jeriespochanów dwóch y pp. dwóch przydanych" (s. 111).

Podobną do erecpochanów od skarbu kościelnego funkcję pełnili ,panowie erecpochani do kościoła łuckiego y wsi Ceperowa". Chodzi tu o zarządców majątku Kościoła ormiańskiego w Łucku i położonej niedaleko Łucka wsi Ceperów, nadanej temuż kościołowi w XV wieku ${ }^{11}$. Tymi dobrami ,zaopiekowała się” gmina ormiańska we Lwowie na początku XVII wieku.

Niewątpliwie istotną dla gminy funkcję pełnili ,panowie prowizorowie do wybierania czynszów y długów y do spraw publicznych". Występują oni też pod innymi nazwami, takimi jak ,prowizorowie od proventów” (czyli prowizorowie od przychodów) lub „prowizorowie proventów publicznych y kościelnych” (czyli prowizorowie od przychodów publicznych i kościelnych, s. 57). Tak jak i inni urzędnicy, byli oni wybierani po dwóch. Istota tej funkcji polegała na pilnowaniu źródeł przychodów gminy i kontroli rachunków. W nazwie urzędu zawarto trzy elementy: wybieranie czynszów z nieruchomości, kontrolę długów i odsetek oraz kontrolę innych przychodów publicznych (gminnych) i kościelnych poprzez rachunki. Sprawozdanie z rachunków prowizorowie z pewnością musieli uczynić, zanim złożyli urząd, na posiedzeniu całej rady. Tych prowizorów przeważnie wybierano parami, jednak ich liczba mogła dojść nawet do czterech $^{12}$.

Z funkcją ,prowizorów od proventów” jest związany urząd pod nazwą ,panowie gospodarze albo lunarowie do dochodzenia summ publicznych". Pochodzące z języka niemieckiego słowo „lunar” może oznaczać urzędnika miejskiego,

10 K. Stopka, Ormianie w Polsce dawnej i dzisiejszej, Kraków 2000, s. 41.

11 S. Barącz, Rys dziejów ormiańskich, Tarnopol 1869, s. 152.

12 „Szlachetni a zacnie sławetni pp. starsi praw Ormian lwow. deputowali z pośrodka siebie pp. collegów swych do odebrania rachunków proventów publicznych, kościelnych y innych przy tym: szlachet. zacnie sławet. pp. Krzysztopha A. Zachnowicza, Gabriela Kaprusiowica, Krzysztopha Łyskiewicza, Mikołaia Steckiewicza. Salva relatione przed wszystkie pp. starsze uczyn[ią]" (s. 109). 
zwłaszcza zarządcę budynków ${ }^{13}$. Ta funkcja pojawia się tylko w jednym akcie elekcji, z 1650 roku (s. 8). Stronę wcześniej znajdujemy zaś zapiskę o wyborze „panów prowizorów do odbierania czynszów”. Ponieważ w kolejnych latach nie pojawiają się już akty wyboru ,panów lunarów”, można założyć dwie możliwości: albo ta funkcja została połączona z funkcją ,prowizorów do odbierania czynszów” $i$ istniała dalej pod nazwą „,prowizorowie od proventów”, albo też był to urząd doraźny, powołany w celu odzyskania konkretnych sum. Fakt, że „lunarowie" zostali wpisani do oficjalnego corocznego spisu wybranych urzędników, przemawia raczej za pierwszą możliwością, gdyż w pozostałych aktach wyborów nie znajdujemy nazw innych urzędów doraźnych.

Kolejnym typem prowizorów pojawiających się w aktach wyborów urzędników gminnych są „panowie szpitalni” (prowizorowie szpitali). Ci prowizorowie zajmowali się sprawami majątkowo-administracyjnymi szpitali ormiańskich. Ostatnią funkcją, na którą rada starszych wybierała spośród siebie „kolegów”, byli „panowie erecpochani monastera y [kościoła] św. Krzyża”. Ci urzędnicy obejmowali w zarząd należący do gminy kościół św. Krzyża z klasztorem. Obiekty te były położone za murami Lwowa ${ }^{14}$.

$\mathrm{Z}$ powyższych wyliczeń wynika, że w corocznych wyborach rada starszych z własnego składu wybierała standardowo po dwóch urzędników na sześć lub siedem funkcji z roczną kadencją. Ze względu na, jak można się domyślać, niepełny skład obradującej rady, prawie zawsze któryś ze starszych był wybierany na więcej niż jeden urząd. Główną funkcją tych urzędników było kontrolowanie spraw finansowych i administracyjnych w różnych sferach majątku gminy i majątku kościelnego. Prawdopodobnie najważniejszą, a z pewnością najliczniej występującą kategorią w zarządzanych elementach majątku były nieruchomości.

Ciekawe jest w omawianym źródle konsekwentne rozróżnienie w listach urzędników na prowizorów i erecpochanów (i jednorazowo gospodarzy-lunarów). Mamy więc cztery typy erecpochanów: „głównych” (bez dopowiedzeń), od skarbu kościelnego, od kościoła łuckiego i wsi Ceperów oraz od klasztoru i kościoła św. Krzyża. Prowizorów natomiast, nie licząc podobnych znaczeniowo lunarów, istniały dwa rodzaje: od przychodów publicznych i kościelnych i od szpitali. Trudno na podstawie powyższej listy przedstawić wyraźne rozróżnienie pomiędzy nazwą ,erecpochan” i ,prowizor”. Wydawałoby się, że terminy te można by stosować zamiennie, jako że „prowizor” to również „rządca, administrator" ${ }^{\prime \prime}$, chociaż nie zawiera w sobie elementu reprezentacji zawartego w słowie „jerespochan”. Tymczasem występująca w omawianym rękopisie konsekwencja w stosowaniu nazw do poszczególnych funkcji zdaje się wskazywać, że istniało

13 S. Linde, Stownik języka polskiego, t. 1, cz. 2, Warszawa 1808.

14 Церква Святого Хреста (Львів), [online] https://uk.wikipedia.org/wiki/Церква_Свя того_Хреста_(Львів), 20 VIII 2017.

${ }^{15}$ Stownik języka polskiego, PWN, [online] sjp.pwn.pl. 
między nimi rozróżnienie. Albo więc te nazwy nadawano poszczególnym urzędom zgodnie ze zwyczajem, albo też zawierały one w sobie nieuchwytną dzisiaj różnicę jakościową. Problem niejasnego nazewnictwa urzędów ormiańskich znany był w dotychczasowej literaturze przedmiotu. Niektórzy autorzy nie rozróżniali tych nazw w ogóle ${ }^{16}$. Rozstrzygnięcie tej kwestii wymagałoby pogłębionych badań.

\section{Urzędy tymczasowe}

Czym innym niż istniejące stale urzędy z roczną kadencją były urzędy czy też funkcje powoływane tymczasowo, do celów doraźnych. Urzędy te były powoływane do życia przez radę starszych i ta sama rada wyznaczała osoby do ich pełnienia, zarówno spośród samej rady, jak i spomiędzy pospólstwa. Zaznacza się tu dość duża swoboda w przydzielaniu kompetencji tym urzędnikom. Wydaje się, że łączenie urzędów z kadencją roczną z tymi tymczasowymi nie było problematyczne, np. na s. 19 znajdujemy erecpochana Krzysztofa Zachnowicza pełniącego jednocześnie funkcję deputata.

W pierwszej kolejności w tej grupie urzędów należy wymienić „exactorów”, czyli poborców, których zadaniem było zebranie od Ormian składek uchwalonych przez radę starszych. Do „wybierania” składek obierano często jednocześnie osoby z rady starszych i pospólstwa, a niekiedy z samego pospólstwa. Liczba wyznaczanych „exactorów” waha się w omawianej części rękopisu od 2 do 10. Prawdopodobnie liczba powoływanych „exactorów” była uzależniona od liczby uchwalonych składek. I tak przykładowo 2 ,exactorów” powołano do zebrania 4 składek (s. 58), a 10 „exactorów” miało zebrać 20 składek (s. 127).

Drugi z urzędów tymczasowych funkcjonuje pod nazwą „deputaci”. Kompetencje tego urzędu nie są nigdzie sprecyzowane, jednak ogólnie można przyjąć, że był to urząd doraźny powoływany przez radę starszych w celu załatwienia konkretnych spraw ważnych dla gminy. Sprawy ważne dotyczyły zwłaszcza kwestii finansowych, przez co kompetencje deputatów mieszały się z kompetencjami „exactorów”. Zazwyczaj chodziło bowiem również o ściąganie pieniędzy, bądź to w formie składek, bądź też długów. Przykładowo dokument z 1651 roku mówi o deputatach powołanych, aby „disponować y wybierać zaczęli długi dla spraw zadwornych natiey naszey" (s. 19). Była to więc w tym wypadku funkcja podobna do kolektorów składek, z tym że źródłem wpływów było tu ściąganie długów. Deputaci-exactorzy mogli być wyznaczeni do pomocy miastu w ściąganiu opłat ogólnomiejskich od Ormian ${ }^{17}$.

16 „Ale chuc był miejscem, gdzie odbywały się wybory prowizorów erespohanów”, zob.: M. Zakrzewska-Dubasowa, Ormianie $w$ dawnej Polsce, Lublin 1982, s. 64.

17 „Pp. starsi e medio sui deputowali na wybieranie 6ci dupell na ratusz na warszawską drogę pp. raycom lwow. przy exactorach miesckich pana Łazarza Krzysztophowica, a to z natiey naszey dla prędszego wybrania" (s. 133). 
Osoby z rady starszych bądź z pospólstwa mogły też być „deputowane” do rozliczenia na podstawie rachunków konkretnych przychodów i wydatków gminy. I tak na s. 111 znajdujemy dokument świadczący, że „relatią uczynili ichmm [ichmościowie] pp. deputaci z powziętych rachunków od pp. prowizorów proventów publicznych, kościelnych y z wydatków na poprawę dzwonicy". Poniżej na tej samej stronie pojawia się przykład „deputowania” dwóch członków rady starszych „na commisią z p. Toloczkiem y z miastem”. Na kolejnej stronie rada wyznacza spośród siebie dwóch deputatów „,do complanatiey z miastem względem dwunastu tysięcy przez commissią albo ugodę z p. Toloczkiem". W tym wypadku deputaci mieli więc na celu załatwienie na ratuszu spraw finansowych gminy, związanych z jakimś bliżej nieopisanym sporem. Ostatnim ciekawym przykładem ,deputowania” członków rady starszych jest wybór w 1667 roku Krzysztofa A. Zachnowicza i Gabriela (Awedika) A. Bernatowicza „za obesłaniem im [jegomości] pa. burmistrza pod te srogie trwogi y zbiegi in casi subitaneo negotio" na członków swoistego „zespołu zarządzania kryzysowego” (s. 139).

Ciekawym przykładem urzędu tymczasowego, rzadziej spotykanego od pozostałych, jest syndyk. W rękopisie znajduje się tylko jeden akt wyboru syndyka Stefana Kirkorowica „patriciusa lwowskiego” w 1662 roku. Z pisma wynika, że syndyk miał charakter przedstawiciela w sądach. I w tym wypadku jednak zadania i kompetencje związane $\mathrm{z}$ tą funkcją nie zostały $\mathrm{w}$ dokumencie wyraźnie sprecyzowane, a jedynie ogólnikowo stwierdzono, że syndyk ma wspierać interes gminy w sądach: „,który aby im [tj. starszyźnie] usługował we wszystkich sprawach ich publicznych, tak za dworem KJMści, iako też y tu w mieście Lwowie, więc także y w inszych sądach koronnych" (s. 88). Wybór syndyka w tym samym dokumencie uzasadniono bieżącymi potrzebami („,bez syndyka starszęnstwo ich obeść się nie może"), a usankcjonowano zwyczajem (,iako y przed tym według zwyczaiów bywało").

Na kartach rękopisu pojawia się jeszcze jeden urząd, a raczej projekt urzędu. Przy okazji proponowanego wyboru wspomnianej piętnastoosobowej reprezentacji pospólstwa rada starszych proponuje wybór spośród tych 15 osób 4 szafarzy, „którzyby spólnie proventami publicznemi, iakiekolwiek są y na potym będą zawiadowali y onemi iako z naylepszym pożytkiem disponowali a za wiadomością naszą na potrzeby publiczne wydawali” (s. 31). Szafarze mieliby więc dysponować przychodami gminy, jak również dbać o ,przymnażanie proventów”. Byłaby to kolejna funkcja związana z zarządzaniem finansami gminy. Jednak jak już wspomniano, nie wiadomo, czy ta „reforma”, polegająca na utworzeniu reprezentacji pospólstwa, a wraz z nią grupy szafarzy, powiodła się. W każdym razie szafarze nie pojawiają się już w późniejszych dokumentach.

Gmina oprócz aparatu administracyjnego zatrudniała ludzi niezbędnych do prowadzenia bieżącej działalności urzędu i sądu gminnego, a więc pisarza i woźnego. Pisarz pojawia się $\mathrm{w}$ omawianym rękopisie kilka razy, $\mathrm{w}$ jednym $\mathrm{z}$ dokumentów jest wymieniony z imienia i nazwiska (Jan Łyskiewicz na s. 135). 
Wzmianki o woźnym nie znajdujemy w tym źródle, jednak z pewnością był obecny i pojawia się w niewiele wcześniejszych źródłach ${ }^{18}$. Do pisarza i woźnego należy dodać jeszcze grupę pracowników kościelnych, a więc „magistra szkolnego" i bakałarza do szkoły dla dzieci czy nauczyciela śpiewu kościelnego dla kleryków (s. 76). Gdyby za kryterium bycia urzędnikiem przyjąć fakt bycia opłacanym przez gminę i świadczenie z tej racji dla niej usług, okazałoby się, że całe duchowieństwo ormiańskie lwowskie należy uznać za osoby pełniące urzędy. I chociaż majątek Kościoła był pod zarządem świeckiej gminy, raczej nie można się posunąć do tak daleko idących wniosków.

$\mathrm{Z}$ analizowanego rękopisu wynika, że kompetencje wielu urzędników w gminie ormiańskiej we Lwowie około połowy XVII wieku nie były do końca sprecyzowane i mieszały się z innymi funkcjami. Przyczyną takiej sytuacji, oprócz braku jednoznacznych przepisów, mógł być fakt, że jedna osoba mogła pełnić kilka urzędów jednocześnie. Zadania urzędników obracały się zasadniczo wokół kwestii finansowych i administracyjnych, a zwłaszcza kontroli majątku, jak również wydatków i przychodów publicznych. Liczba urzędników nie wydaje się wielka, a aparat urzędniczy nie był zbyt rozbudowany.

OGÓLNY SYSTEM FINANSOWANIA POTRZEB GMINY ORMIAŃSKIEJ WE LWOWIE Przechodząc od badania struktury gminy ormiańskiej do spraw finansowych, warto przyjrzeć się przychodom i wydatkom gminy. Jak wyglądało finansowanie potrzeb gminy na co dzień według dokumentów z części pierwszej źródła?

\section{Przychody}

W świetle danych zawartych w omawianym rękopisie można wyróżnić następujące źródła przychodów gminy ormiańskiej we Lwowie: składki oraz odsetki od długów. Źródła wymienionych przychodów nazywano ,proventami publicznymi i kościelnymi”. Pieniądze pochodzące z tych źródeł, należące ogólnie do całej gminy, były „sumami publicznymi” bądź „,pieniędzmi publicznymi” (s. 11). W źródle pojawiają się też „długi publiczne” (s. 28).

Część gotówki przechowywali starsi ormiańscy we własnej skarbonie (,carbona pp. starszych", s. 99). Do tego dochodziła jeszcze skarbona bractwa religijnego (,skrzynka bracka natiey naszey ormiańskiey”, s. 21). Z tych skarbon pobierano w potrzebie środki (zarówno gotówkę, jak i przedmioty) przy założeniu przyszłego zwrotu pożyczki czy też wykupienia zastawu. Przykładowo na s. 64 w rozliczeniu z 1656 roku pojawia się pozycja „do skrzynki złotych tysiąc”, co sugeruje postulat zwrotu wyjętych wcześniej pieniędzy bractwa bądź „,publicznych”. Podobnie na s. 21 uchwalono zbiórkę w wysokości 1000 złotych na prezent dla króla Jana Kazimierza i pieczętarzy z okazji ich przyjazdu do Lwowa po

18 E. Tryjarski, Zapisy sądu duchownego Ormian miasta Lwowa za lata 1625-1630 w języku ormiańsko-kipczackim, Kraków 2010, s. 167. 
bitwie pod Beresteczkiem, jednak „na razie składka bydź nie mogła, dla tegosz z skrzynki brackiey pewne fanty odebrawszy według karty niżey opisaney [...] do brackiey skrzynki zasię powrócone bydź maią".

\section{Składki}

Przejdźmy do omówienia poszczególnych elementów przychodów gminy. W pierwszej kolejności zwracają uwagę dość częste uchwały rady starszych ormiańskich w sprawie zbierania składek pieniężnych. Dokumentów z tym związanych jest w pierwszej części źródła 13. Składki określane są też łacińskim terminem collecta bądź kipczackim słowem jasach ( jasak). Jak wynika z omawianego źródła, składki te uchwalała rada starszych po zasięgnięciu opinii pospólstwa (,zgodnie z pp. pospolitemi”, s. 37) z tego względu, że pieniądze były zbierane zarówno od starszyzny, jak i ,pospolitych" (s. 4). Jednak to rada starszych miała ostatnie słowo w tej kwestii, o czym świadczy prośba pospólstwa o zmniejszenie sumy składek w 1666 roku, ,gdysz natia iest zubożałą”, oraz nieuwzględnienie tej prośby przez starszych (s. 127).

Składki uchwalano do zebrania w określonej liczbie, na przykład ,uchwała jasachów № 4” (s. 4), ,uchwalili № 5 collect” (s. 37). Taki sposób uchwalania składek mógłby sugerować, że istniała jakaś z góry ustalona wysokość jednej składki, określona zwyczajem bądź odrębnymi uchwałami. Poniższa tabela przedstawia wszystkie występujące w źródle uchwały związane ze zbieraniem składek.

\begin{tabular}{|l|c|c|}
\hline \multicolumn{1}{|c|}{ Rok } & Liczba składek & Suma zł do zebrania \\
\hline 1649 & 4 & 1600 \\
\hline 1650 &. & 3000 \\
\hline 1651 &. & 1000 \\
\hline 1653 & 2 &. \\
\hline 1653 & 5 &. \\
\hline 1653 & 6 &. \\
\hline 1654 &. &. \\
\hline 1656 & 4 &. \\
\hline 1657 & 4 &. \\
\hline 1663 & 15 &. \\
\hline 1665 &. & 1000 \\
\hline 1666 & 20 & 3000 \\
\hline 1666 & 20 & \\
\hline
\end{tabular}

Tabela 2. Składki uchwalone w latach 1649-1666

Tylko w trzech wypadkach liczba uchwalonych składek jest podana w źródle razem z łączną uchwaloną sumą pieniędzy do zebrania. Jeśli w tych trzech przy- 
padkach podzielić łączną sumę przez liczbę składek, otrzymujemy kwoty 400, 50 i 150 złotych. Wynika z tego, że nie było określonej z góry wysokości jednej składki, która obowiązywałaby podczas każdego zbierania uchwalonej kwoty.

Jedną składkę należałoby więc rozumieć raczej w kontekście czasowym, jako jednorazowe zbieranie pieniędzy wśród członków gminy. Być może zbieranie składek było rozłożone na raty; w trzech przytoczonych przypadkach byłoby to $4 \times 400$ złotych, $20 \times 50$ złotych i $20 \times 150$ złotych. W ten sposób zmniejszano jednorazowe obciążenie finansowe wśród członków gminy.

Jak wspomniano, zbieraniem składek zajmowali się specjalnie do tego za każdym razem wyznaczani „exactorzy”. Ci sami „exactorzy” lub też deputaci mieli za zadanie oszacować majątek członków gminy przed zebraniem składek, aby wiedzieć, ile kto powinien dać. Kilkakrotnie w kontekście uchwał o składkach pojawia się metoda liczenia należności: 15 groszy ( $1 / 2$ złotego) od każdego 1000 złotych majątku (na przykład s. 4). Majątek szacowano na podstawie zasobów gotówki (,z summ”), długów („od creditów”) i nieruchomości („,od dóbr stoiących", s. 45). Podobne oszacowanie miało miejsce przy obliczaniu, ile kto powinien zapłacić na okup dla Chmielnickiego i Tuhaj beja, przy czym wtedy wysokość składki była znacznie wyższa.

Wydaje się, że system zbierania składek był wysoce nieskuteczny, co miało odzwierciedlenie również $\mathrm{w}$ przypadku zbierania sum na okup z 1648 roku. $\mathrm{W}$ wielu miejscach $\mathrm{w}$ omawianym rękopisie pojawia się problem ze zbieraniem pieniędzy nie tylko na bieżące wydatki, ale także zaległych „,collect przeszłych y donatiw także y retent" (s. 127).

\section{Czynsze i długi}

„Wybieraniem” czynszów i obsługą długów zajmowali się wspomniani już prowizorowie. Gmina z pewnością czerpała przychody z obrotu kapitałem i nieruchomościami. Świadczą o tym zarówno listy dłużników gminy zawarte w drugiej części rękopisu, jak i dowody wprost na taką działalność zawarte w części pierwszej. Na s. 83 i 90 rękopisu mamy przykład przeznaczania sum uzyskanych z wyderkafu na cele opieki społecznej. W tych dwóch dokumentach Janowa Bernatowa prosi radę starszych o dalsze wsparcie finansowe w postaci 80 złotych rocznie ,z summy viderkaff pochodzącey na ubogie fundowaney” (s. 90). Z kolei na s. 117 Krzysztof A. Bernatowicz rozlicza się z radą starszych z przychodów z młyna i „czynszów pochodzących od niego”.

\section{Wydatki}

Gmina czerpała przychody z różnych źródeł, ale miała też wiele wydatków. Pieniądze ze składek, czynszów itp. były wydawane na sprawy dotyczące gminy, takie jak wysłanie deputatów do Warszawy czy zapłata jurgieltu (jak się można domyślać - były to pensje dla zaprzyjaźnionych urzędników, s. 10). Pieniądze przeznaczano na rozmaite prezenty, na przykład dla przyjeżdżających do Lwowa 
dostojników królewskich i samego króla (s. 4). Gmina musiała także płacić podatki narzucone z góry, czy to przez miasto, czy przez administrację centralną. Tak należy rozumieć wspominane w rękopisie zbiórki na donatywy (na przykład s. 137). Wreszcie gmina miała też własne długi do spłacenia (s. 10).

Składki na okupy, które zostaną szerzej omówione w następnej części artykułu, można uznać za nadzwyczajny i wysoce niepożądany rodzaj wydatków gminy.

\section{Analiza liczebności i struktury majątkowej gminy ormiańskiej we Lwowie na podstawie części drugiej rękopisu}

\section{OPIS ZAWARTOŚCI CZĘŚCI DRUGIEJ RĘKOPISU}

Zawarta w drugiej części tekstu analiza struktury i finansów gminy ormiańskiej we Lwowie około połowy XVII wieku była konieczna dla zrozumienia pojęć pojawiających się $\mathrm{w}$ tej części. Wykorzystane tutaj zostaną dokumenty z części drugiej, w związku z tym zasadne wydaje się szczegółowe przedstawienie zawartości drugiej części źródła.

Jak już wspomniano, druga część rękopisu zawiera nieuporządkowany zbiór około $20^{19}$ szybko i najczęściej niezbyt starannie kopiowanych dokumentów z lat 1647-1713, przedzielonych wieloma pustymi kartami. Wydaje się, że najbardziej przydatne może być ułożenie tych dokumentów w kolejności chronologicznej.

\begin{tabular}{|l|c|l|}
\hline \multicolumn{1}{|c|}{ Strony } & Rok & \\
\hline $147-148$ & 1647 & Rejestr przychodów gminnych z lat 1614-1622 \\
\hline $149-150$ & 1647 & Rejestr dłużników gminy \\
\hline $151-154$ & 1647 & Rejestr dłużników zadłużonych na majątku kościelnym (1614-1647) \\
\hline 155 & 1647 & Korekta bilansu przychodów i rozchodów (1614-1647) \\
\hline $156-165$ & 1653 & $\begin{array}{l}\text { Rejestr Ormian i sum do zapłacenia przez nich (po wyrównaniu) na } \\
\text { okup z 1648 roku dla Chmielnickiego i Tuhaj beja }\end{array}$ \\
\hline $185-194$ & 1704 & $\begin{array}{l}\text { Spis osób i instytucji Iwowskich z sumami do zapłacenia na okup dla } \\
\text { Szwedów w 1704 roku }\end{array}$ \\
\hline 199 & 1704 & Bilans okupu miasta Lwowa dla Szwedów \\
\hline $200-201$ & 1704 & Bilans kwot zebranych na okup dla Szwedów \\
\hline $202-203$ & 1704 & Rejestr kwot danych na okup dla Szwedów przez samych Ormian \\
\hline 141 & 1712 & Akt wyboru sędziów (starszych) ormiańskich \\
\hline 196 & 1712 & Krótki inwentarz przedmiotów ze skarbca katedry ormiańskiej \\
\hline 143 & 1713 & Akt wyboru sędziów (starszych) ormiańskich \\
\hline $171-172$ & 1713 & Luźny zbiór wpisów z różnych rejestrów \\
\hline $173-175$ & 1713 & Rejestr sum utraconych z lat 1647-1713 \\
\hline
\end{tabular}

19 Dokładna liczba pism jest zależna od tego, które wpisy uznamy za osobne dokumenty. 


\begin{tabular}{|l|c|l|}
\hline Strony & Rok & Treść \\
\hline 197 & 1713 & Krótki rejestr przedmiotów należących do gminy \\
\hline
\end{tabular}

Tabela 3. Zawartość drugiej części rękopisu

Szczególnie interesujące będą wyliczenia związane z okupami czy też kontrybucjami z lat 1653 i 1704, gdyż zawierają one najwięcej danych liczbowych i osobowych pozwalających uzyskać informacje na temat struktury społeczno-majątkowej lwowskiej gminy ormiańskiej.

\section{OBLĘŻENIA LWOWA W LATACH 1648-1704 - RYS HISTORYCZNY}

W odniesieniu do treści dokumentów z części pierwszej i drugiej rękopisu można ogólnie stwierdzić, że dominującym w nich wątkiem jest kwestia okupów, które musieli zapłacić mieszkańcy Lwowa, w tym Ormianie, najeźdźcom - Chmielnickiemu i Tuhaj bejowi w 1648 roku oraz Szwedom w 1704 roku. Nawet w trzeciej części źródła, która jest w zasadzie inwentarzem przedmiotów, pojawiają się dopiski na ten temat ${ }^{20}$. Dlatego $w$ tym miejscu, w celu stworzenia tla dla badanych pism, warto pokrótce przedstawić rys historyczny o oblężeniach Lwowa z lat 1648-1704.

W 1648 roku armia Bohdana Chmielnickiego wraz z posiłkami tatarskimi pod dowództwem Tuhaj beja przemieszczała się na zachód, rozbijając po drodze kolejne polskie armie. Na początku października powstańcy (bądź buntownicy, w zależności od punktu widzenia) i Tatarzy podeszli pod Lwów i rozpoczęli oblężenie. Miasto nie było do niego przygotowane, stan fortyfikacji pozostawiał wiele do życzenia, a dobrze wyposażonych obrońców było niewielu. $Z$ drugiej strony Chmielnicki dysponował ogromną armią, która jednak składała się, obok regularnych oddziałów kozackich i Tatarów, głównie z mizernie uzbrojonej i równie źle bądź wcale nieszkolonej czerni chłopskiej. Dlatego też, biorąc pod uwagę zbliżającą się zimę, Chmielnicki musiał rozważać możliwość zadowolenia się okupem od miasta.

Tak też się stało. Po kilku nieudanych szturmach atakujących armii, powodujących wysokie ofiary po obu stronach, i rozkazie podpalenia przedmieść wydanym przez dowódcę obrony Krzysztofa Arciszewskiego, ostatecznie oblegający zgodzili się na wypłacenie przez Lwów okupu. Wysokość kwoty okupu wyniosła

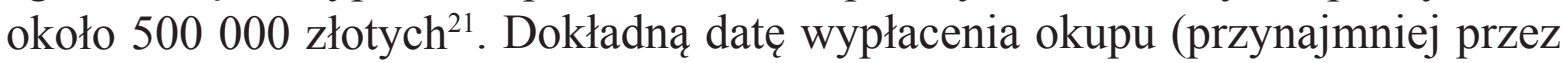

${ }^{20}$, „Na ołtarzu ś. Krzyża w żamadunie na crucifixie korona cierniowa ze srebra złocistego”, dopisek: „To zabrali Szwedzi, a teraz dał na to mieysce p. Krzysztof Jerzy Jurkiewicz koronę cierniową" (s. 216).

${ }^{21}$ A. Czołowski podaje sumę 200000 dukatów, przy czym zaznacza, że z powodu wcześniejszych wydatków na zaciągnięcie oddziałów przez Wiśniowieckiego udało się zebrać jedynie niecałą połowę tej kwoty w gotówce, klejnotach i towarach, zob.: A. Czołowski, Historja Lwowa od roku 1600 - do roku 1772, Lwów 1927, s. 12. L. Podhorodecki przelicza owe 
Ormian) znajdujemy w omawianym rękopisie: był to 15 października 1648 roku (s. 25). Oblężenie natomiast zostało zwinięte 24 października, po czym Chmielnicki z armią wymaszerował w stronę Zamościa.

Dramatem dla mieszczan lwowskich był nie tylko sam okup, lecz również fakt, że kilka dni przed nadciągnięciem wojsk Chmielnickiego wyłożyli wyższą od okupu sumę 1300000 złotych na zaciąg wojska przez Jeremiego Wiśniowieckiego. Wiśniowiecki jednak nie podjął się obrony Lwowa i z zebranym wojskiem oddalił się (według lwowian - uciekł) z miasta w stronę Zamościa i Warszawy, a miasto musiało płacić po raz drugi ${ }^{22}$. Niemniej wypłacenie okupu miało tę zaletę, że miasto nie zostało splądrowane, co mogło pociągnąć za sobą znacznie wyższe straty, zarówno materialne, jak i osobowe.

W trakcie oblężenia rozmowy z Chmielnickim w imieniu miasta prowadzili między innymi Ormianie, na przykład Krzysztof Zachnowicz ${ }^{23}$. Jest to postać wielokrotnie pojawiająca się w omawianym rękopisie jako Krzysztoph Awedik Zachnowicz (lub Zachnowic), wieloletni erecpochan ormiański i z pewnością jedna $\mathrm{z}$ ważniejszych dla gminy ormiańskiej postaci tego okresu pod względem politycznym, chociaż ze spisów można wyczytać, że nie należał do grupy najbogatszych Ormian.

Pod koniec września 1655 roku doszło do drugiego, kilkutygodniowego oblężenia Lwowa przez wojska Bohdana Chmielnickiego i Wasyla Buturlina i tu również negocjatorom, w tym Ormianom (między innymi znowu Krzysztofowi Zachnowiczowi oraz Zachariaszowi Gamockiemu - Ormianinowi w służbie szwedzkiejej) udało się przekonać Chmielnickiego do przyjęcia okupu ${ }^{25}$. Okup został wypłacony 20 października, oblężenie zwinięto całkowicie 10 listopada.

O oblężeniu z 1648 roku pojawiają się liczne wzmianki w omawianym źródle. Są też ślady przebywania króla Jana Kazimierza we Lwowie w 1649, 1651 i 1653 roku (s. 4, 20, 37). W tym czasie (1656) Jan Kazimierz złożył też słynne śluby lwowskie, a na początku 1657 roku pod miastem stały wojska siedmiogrodzkie.

Niestety po 1667 roku w omawianym źródle następuje luka, aż do dokumentów z 1704 roku. Między tymi latami doszło między innymi do oblężenia Lwowa przez Turków (we wrześniu i październiku 1672 roku) i miasto znowu musiało

zażądane przez Chmielnickiego 200000 dukatów na 1200000 złotych, w związku z czym ostatecznie wypłaconą kwotę ocenia na 500000 złotych, zob.: L. Podhorodecki, Dzieje Lwowa, Warszawa 1993, s. 76.

22 A. Czołowski, Historja Lwowa, s. 10.

23 S. Barącz, Rys dziejów ormiańskich, s. 122; idem, Żywoty sławnych Ormian, s. 394.

${ }^{24}$ Idem, Rys dziejów ormiańskich, s. 123; idem, Żywoty sławnych Ormian, s. 394; A. A. Zięba, Zachariasz Gamocki, [online] http://www.wiki.ormianie.pl/index.php?title= Zachariasz_Gamocki, 3 V 2017.

25 A. Czołowski podaje kwotę okupu 60000 złotych polskich, zob.: A. Czołowski, Historja Lwowa, s. 13. L. Podhorodecki podaje natomiast kwotę 20000 złotych, zob.: L. Podhorodecki, Dzieje Lwowa, s. 79. 
się okupić, przy czym z ustalonej kwoty 80000 talarów udało się zebrać jedynie 5000 czerwonych złotych, a na poręczenie reszty dano zakładników ${ }^{26}$. Wśród negocjatorów z Turkami znów znaleźli się Ormianie, w tym Gabriel (Awedik) Bernatowicz i Jakub Jaśkiewicz, obaj wydani potem na zakładników. Ich nazwiska znajdujemy również na kartach omawianego rękopisu, w dokumentach z lat sześćdziesiątych XVII wieku. Jeśli informacje dotyczą tego samego Jakuba Jaśkiewicza, to ze źródła możemy się dowiedzieć, że był księdzem zatrudnionym w charakterze nauczyciela śpiewu kościelnego w 1660 roku (s. 76). Z kolei Gabriel Awedik Bernatowicz, występujący częściej pod imieniem Awedik, był pospolitym ormiańskim awansowanym na starszeństwo w 1660 roku (s. 73).

Kontrybucji w omawianym okresie Lwów musiał podobno płacić jeszcze więcej ${ }^{27}$, jednak najgorsze spośród wydarzeń wojennych nadeszło 5 września 1704 roku. Wtedy to pod Lwów przybyli Karol XII i generał Magnus Stenbock, którzy z oddziałem 1400 żołnierzy niemal z marszu zdobyli miasto, po czym nałożyli na Lwów kontrybucję w wysokości 300000 talarów, nie licząc wielodniowego rabunku ze strony Szwedów. Taka porażka w starciu z nielicznym (chociaż dobrze wyszkolonym) wrogiem świadczy o słabości Lwowa w tym okresie, wyniszczonego wieloletnimi działaniami wojennymi. Zwłaszcza stan przestarzałych i prawie nieremontowanych fortyfikacji był opłakany, co znacznie ułatwiło Szwedom wzięcie miasta szturmem. Warto dodać, że było to pierwsze zdobycie Lwowa od czasów średniowiecznych.

Straty materialne i osobowe Lwowa w latach 1648-1704 były bardzo wysokie. Kilka oblężeń i okupów, pożary i zarazy, wreszcie złupienie miasta przez Szwedów - wszystkie te czynniki sprawiły, że Lwów zaczął zmierzać do całkowitej utraty swego znaczenia i ruiny materialnej w XVIII wieku. Wraz z miastem upadło znaczenie bogatej i wpływowej lwowskiej gminy ormiańskiej.

\section{Koekwacja po ZapŁaceniu OKupu dla Chmielnickiego i Tuhaj Beja W 1648 ROKU}

Okup dla wojs Bohdana Chmielnickiego i Tuhaj beja w 1648 roku był dużym obciążeniem finansowym dla Lwowa, zwłaszcza że, jak już wspomniano, nie była to pierwsza poważna składka mieszkańców miasta związana $\mathrm{z}$ tą wojną. W omawianym źródle jest kilka dokumentów, które świadczą o sposobie zapłacenia okupu i późniejszych rozliczeniach z tym związanych. Już pierwszą część rękopisu otwiera zapis posiedzenia rady starszych ormiańskich z 25 marca

26 A. Czołowski, Historja Lwowa, s. 15; S. Barącz, Rys dziejów ormiańskich, s. 126. L. Podhorodecki podaje 100000 złotych jako kwotę zażądaną przez Turków, obniżoną następnie do 20000 złotych, z czego zebrano tylko 5000 złotych, zob.: L. Podhorodecki, Dzieje Lwowa, s. 88.

27 Ł. Charewiczowa podaje, że kontrybucja dla Szwedów w 1704 roku była już trzynastą z rzędu, zob.: Ł. Charew ic zow a, Lwów na przełomie XVII $i$ XVIII wieku, w: Studja z historii społecznej i gospodarczej poświęcone prof. dr Franciszkowi Bujakowi, Lwów 1931, s. 349. 
1649 roku związanego z tą sprawą (s. 1). Rozliczanie kwot zapłaconych na okup pomiędzy mieszkańcami Lwowa zaczęło się więc kilka miesięcy po zwinięciu oblężenia. Ostatnie zaś dokumenty z tym związane znajdujemy w omawianym rękopisie pod rokiem 1657 (s. 59). Cały proces trwał kilka lat, a możliwe, że jeszcze dłużej, bo ostatnie pismo wcale nie zamyka całej sprawy. Na podstawie rękopisu można podejrzewać, dlaczego rozliczenie trwało tyle lat. Przede wszystkim było to spowodowane ciągłym prowadzeniem działań wojennych oraz zarazą: „dla pewnych przeszkód, a zwłaszcza woien koronnych a potym y nawiedzenia boskiego powietrzem y inszych różnych przeszkód do swey perfectiey pomienioną coaequatią przywieść nie mogli” (s. 25). Dodatkowo trzeba pomyśleć o wysokim stopniu złożoności takiego rozliczenia pomiędzy mieszczanami i w obrębie poszczególnych grup etniczno-religijno-prawnych.

Dlaczego po zapłaceniu okupu w 1648 roku mieszkańcy Lwowa, w tym Ormianie, potrzebowali dalszych rozliczeń pomiędzy sobą? Wysokość składek pieniężnych obowiązujących każdego członka gminy wyznaczano, przynajmniej wśród Ormian, po oszacowaniu jego majątku. Problem polegał jednak na tym, że podczas oblężenia prawdopodobnie nie było czasu, by szacować, ile kto powinien dać zgodnie ze stanem majątkowym. Mieszkańcy, zwłaszcza bogatsi, „zrzucili się" więc na okup, dając gotówkę, klejnoty, towary, ile było potrzeba do osiągnięcia ustalonej kwoty. Oczywiście w tej sytuacji pośpiechu i zagrożenia część osób zapłaciła więcej, a część mniej, niż teoretycznie powinna. Stąd też gdy zagrożenie minęło, osoby, które dały za dużo, zaczęły domagać się ,koekwacji" (coaequatia), czyli wyrównania poniesionych przez nie nakładów. Władze miejskie zarządziły koekwację generalną, która jednak przeciągnęła się aż do 1656 roku, jeszcze po zapłaceniu drugiego okupu dla Chmielnickiego w 1655 roku. Tymczasem Ormianie mieli rozliczyć się między sobą.

Najbogatsi Ormianie, którzy dali najwięcej na okup w 1648 roku, najszybciej też zaczęli walczyć o odzyskanie nadpłaconych pieniędzy. W piśmie z 25 marca 1649 roku są to Krzysztof Awedik Bernatowicz oraz Iwaszko Torosowicz. Nie zostali oni, co prawda, usatysfakcjonowani gotówką, z czym mieli poczekać do "generalney coaequatiey”, lecz rada starszych (której zresztą Bernatowicz był członkiem) uzgodniła, , aby tymczasem membrany tak pp. starsi, iako y wszyscy pospolici na podobne summy wydali”, wszystko w celu, by ,ieden od drugiego w pośrodku natiey krzywdy nie ponosił, y żeby ieden za wielu nie cierpiał" (s. 1). Obaj panowie dostali więc weksle z czasem zapłaty za ich stracone pieniądze i towary. Już na s. 2 rękopisu, pod datą 12 czerwca 1649 roku, następuje wyliczenie osób, od których Krzysztof Awedik Bernatowicz, zgodnie z uchwałą z 25 marca 1649 roku, jest uprawniony do odzyskania łącznej kwoty 10000 złotych (do świętych Szymona i Judy, czyli do 28 października). Z kolei na s. 3 widnieje identyczne pismo z 14 czerwca dotyczące Iwaszka Torosowicza, któremu także mocą uchwały z dnia 25 marca rada starszych pozwala „odebrać” kwotę 6000 złotych od wymienionych osób, również do dnia świętych Szymona i Judy. 
KOEKWACJA MIĘDZY SAMYMI ORMIANAMI - DOKUMENTY Z LAT 1652 I 1653 Kluczowe pismo dotyczące wyrównania opłat złożonych na okup dla Chmielnickiego i Tuhaj beja pojawia się na s. 25 rękopisu, pod datą 2 maja 1652 roku. Jest to uchwalenie przez radę starszych ormiańskich koekwacji, czyli wyrównania, wśród samych Ormian uzasadnione tym, że osoby, które wyłożyły towary w 1648 roku, nie zostały dotychczas usatysfakcjonowane, „drudzy zasię mało co, abo nic na ten okup dotąd nie dali”. Nacisk na wyrównanie musiał więc iść ze strony najbogatszych, którzy dali najwięcej na okup, natomiast biedniejsi woleliby zapewne, żeby cała sprawa odwlekała się jak najdłużej.

W celu przeprowadzenia wyrównania rada starszych wyznaczyła spośród siebie na deputatów czterech „kolegów” i do tego sześciu przedstawicieli pospólstwa. Od razu też postanowiono rozwiązać typowy dla społeczności kupieckiej problem przewidywanej nieobecności niektórych deputatów podczas prowadzenia wyliczeń poprzez stwierdzenie, że nie potrzeba obecności wszystkich deputatów, by koekwacja się „odprawowała” (s. 26). Zadaniem deputatów było po pierwsze oszacowanie majątku członków gminy, po drugie wyznaczenie na tej podstawie sum, które każdy powinien zapłacić na okup, po trzecie ściągnięcie od nich należności bądź oddanie im nadpłaconych kwot. Majątek, podobnie jak w przypadku składek, szacowano (,taxowano”) na podstawie posiadanych nieruchomości (kamienice, kramy bogate, kramy ubogie, ogrody), dóbr ruchomych, do których zaliczano gotówkę, towary i inne rzeczy, oraz zaciągniętych kredytów. Do wyrównania wliczały się również wszelkie „membrany”, „asygnacje” itd., wydane na poczet kwot i towarów danych na okup od 1648 roku.

Wydaje się, że przy okazji wyrównania rada starszych postanowiła spróbować ściągnąć część własnych długów, bo tak chyba należy rozumieć polecenie dodania do ,iusz wynalezioney summy na okup miasta nieprzyiacielowi wydaney [...] wszystkie dhugi publiczne iakiekolwiek się po te czasy ukażą y naydować będą" (s. 26-27). Cała operacja miała dotyczyć wszystkich starszych i pospolitych, zarówno będących na miejscu, jak i nieobecnych (będących w drodze $\mathrm{z}$ towarami). Od razu też zagrożono, że osobie sprzeciwiającej się ustaleniom wyznaczonych deputatów grozi proces i więzienie, do czasu spłacenia całej wyznaczonej przez deputatów kwoty. Sądząc po liczbie osób, przy których imionach na liście koekwacji widniał później dopisek „nie dał”, rada starszych musiałaby wytoczyć procesy większości członków gminy ormiańskiej we Lwowie. Te groźby mogły zapewne skłonić Ormian do niesprzeciwiania się ustaleniom deputatów, ale z pewnością nie nakłoniły wszystkich do zapłacenia od razu wyznaczonych im sum.

Zwróćmy uwagę na szerokie uprawnienia, jakie przyznała rada starszych deputatom mającym sporządzić rejestr do koekwacji. Przede wszystkim nie byli oni bezstronną, zewnętrzną komisją, gdyż wiadomo było, że będą szacować między innymi własne majątki, jak również majątki krewnych i znajomych. Mogli oni więc zarówno niedoszacować czyjś majątek, co dawało podstawę do domagania 
się zwrotu rzekomo nadpłaconych kwot, jak i zawyżyć szacunki i w ten sposób zmusić kogoś do zapłacenia niewłaściwych sum. Można powiedzieć, że przed niedoszacowaniem własnego majątku mogli członków komisji powstrzymać jedynie pozostali deputaci. Ale nawet jeśliby przyjąć, że wszyscy deputaci byli uczciwi, to trudno stwierdzić, czy mogli dysponować obiektywnymi narzędziami do oszacowania wartości wszystkich majątków. To wszystko pasuje do obrazu, zgodnie z którym wyrównanie nie przebiegało łatwo, lecz było ciągnącym się latami pasmem konfliktów i sporów.

W trakcie koekwacji deputaci mieli prowadzić rejestr kwot wyznaczonych do zapłacenia poszczególnym członkom gminy, a oprócz tego w osobnym rejestrze mieli zapisywać kwoty długów publicznych do zapłacenia (s. 28). Dochodzimy w ten sposób do najciekawszego i najbogatszego w dane dokumentu, który szczęśliwie został wpisany do rękopisu w drugiej jego części. Oprócz uchwał związanych z koekwacją mamy też obraz próby jej rzeczywistego przeprowadzenia.

\section{OPIS REJESTRU KOEKWACJI Z 1653 ROKU}

Rejestr koekwacji pomiędzy Ormianami znajduje się na s. 156-165 omawianego rękopisu. Sam rejestr pochodzi z 1653 roku, czyli od kilku do kilkunastu miesięcy po inicjującej operację uchwale z 1652 roku (dokładna data stworzenia rejestru nie jest podana), a został wpisany do badanej księgi w 1713 roku, o czym świadczy dopisek kopisty na s. 165. Rejestr jest więc w całości wpisany jedną ręką (kopisty). Pismo nie jest staranne i wychodzi poza obramowanie strony, nie ma też żadnych linii, według których wpisywałby kopista, w tekście są skreślenia, poprawki i miejsca nieczytelne. Dane wpisano w pojedynczej kolumnie.

Tytuł dokumentu brzmi: „Regestr koekwatiey generalney wzglendem summ na okup Chmielnickiemu y Tohaybegowi podczas oblężenia miasta Lwowa, z natiey naszey wydaney, także y pewne części długów publicznych, sposobem niżey opisany \& sporządzony \& stosując się ze wszystkim do uchwały generalney, która unanimi consensu przy zacnie sławnych pp. starszych praw Ormia. lwow. i publiki wszelkiey in A. 1652 die 2 May stanęła, podług którey taxa wszystkich dóbr tak stoiących iako y ruchomych przez pp. deputaty iest uczyniona, y którzy $\mathrm{z}$ natiey tak wiele powydawali dostatecznie $\mathrm{w}$ tym regestr[ze] wystawione iest y którzy nie wydali”. Z tytułu wynika, że rejestr koekwacji i rejestr długów, które zgodnie z uchwałą rady starszych z 2 maja 1652 roku miały być opracowane osobno, zostały ostatecznie połączone w jedno.

Poniżej tytułu dokumentu następuje wyliczenie Ormian, których dotyczyło wyrównanie. To łącznie niecałe 150 pozycji w spisie. Liczba ta nie równa się jednak liczbie osób występujących w dokumencie, ponieważ po pierwsze pod jedną pozycją występują zarówno pojedyncze osoby (mężczyźni lub kobiety), jak również grupy osób (na przykład: mężczyzna z matką, kobieta z zięciem, sieroty), a po drugie niektóre nazwiska występują więcej niż raz i niekiedy nie można stwierdzić, czy dane pozycje dotyczą tej samej osoby, czy różnych ludzi. 
Każdej pozycji w spisie jest przypisanych pięć danych: 1. imię, nazwisko bądź nazwiska jednej lub więcej osób, 2. suma majątku oszacowanego przez deputatów dla danej osoby (osób) wyrażona w złotych polskich, 3. wysokość składki wyrażona w formie procentu od majątku (taka sama dla wszystkich), 4. wyliczenie kwoty do zapłaty, 5. uwagi w formie słownej na temat zapłacenia bądź niezapłacenia wyliczonej kwoty przez daną osobę (osoby).

W przypadku omawianej koekwacji wysokość składki ustalono na 531/3 złotego (53 złote 10 groszy) od każdego 1000 złotych oszacowanego majątku; innymi słowy: ustalono, że 51/3 procenta majątku członków gminy ma wystarczyć do rozliczenia części kwoty okupu przypisanej przez miasto Ormianom. Przykładowo osoba, której majątek oszacowano na 3000 złotych, powinna zapłacić $3 \times 53 \frac{1}{3}=160$ złotych. Wysokość składki była zbliżona do kwoty ustalonej przez radę miejską bądź nawet taka sama $(5 \%)^{28}$. Wydaje się, że było to bardzo duże obciążenie, biorąc pod uwagę fakt, że zwyczajowa składka w gminie ormiańskiej wynosiła 15 groszy od każdego 1000, czyli ponad 100 razy mniej. Do tego dodać należy wszystkie inne wydatki wojenne ponoszone przez miasto, w tym Ormian, od 1648 roku, koszty osobowe wojny i zarazy itd.

Każda strona koekwacji zawiera podsumowanie kwot na tej stronie, przy czym na pierwszej stronie dokumentu tych podsumowań jest kilka. Cała kwota, którą powinni według tych wyliczeń zapłacić Ormianie na okup, znajduje się na s. 165 i wynosi 91421 złotych 10 groszy. Od razu podano też przeliczenie tej kwoty na talary bite: 30473,23 , co oznacza, że 1 złoty $=3$ talary bite.

W dokumencie koekwacji zdarzają się błędy. Na s. 157 pojawia się wyliczenie dla Krzysztofa J[ana] Bernatowicza, starszego ormiańskiego, wieloletniego erecpochana i brata stryjecznego Krzysztofa Awedika Bernatowicza ${ }^{29}$. Majątek Krzysztofa Jana oszacowano na 80000 złotych, co po przeliczeniu $\left(8 \times 53^{1 / 3}\right)$ daje do zapłaty $4266^{2} / 3$ złotego (wpisano samo 4266 złotych). Do tego w następnej pozycji doliczono „97 retent z pewnych jasachów” w wysokości 216 złotych, co po podsumowaniu pod kreską dało 4482 złote z niejasnym dopiskiem „reszty przy p. Krzysztofowiczu”. Wydaje się, że sumując na końcu strony do 12308 złotych, pisarz pomylił się i policzył dwa razy kwotę 4482 złote (dwa razy $4266+216)$. Gdzieniegdzie zdarzają się też pomyłki w wyliczeniu kwoty do zapłaty, np. na s. 163 majątek Kaspra Der Kasprowicza oszacowano na 3500 złotych, czyli kwota do zapłaty w jego wypadku powinna wynieść $3,5 \times 53^{1 / 3}=186^{2} / 3$ złotego, podano zaś kwotę do zapłaty liczoną od 4000 złotych, czyli $213^{1 / 3}$ złotego. Na tej samej stronie osoba podsumowująca kwoty pomyliła się o 100 złotych (4740 zamiast właściwych 4640 złotych). Pomijając te

${ }^{28}$ W. Łoziński, Patrycyat i mieszczaństwo lwowskie w XVI i XVII wieku, Lwów 1892, s. 169.

${ }^{29}$ A. A. Zięba, Krzysztof Bernatowic, [online] http://www.wiki.ormianie.pl/index.php? title=Krzysztof_Bernatowic, 7 V 2017. 
i kilka innych, nielicznych pomyłek, ogólnie należy jednak ocenić omawiany rejestr jako dokładny i wiarygodny.

\section{METOdOLOGIA OPRACOWANIA UJEDNOLICONEJ TABELI NA PODSTAWIE REJE- STRU Z 1653 ROKU}

Do analizy rejestru koekwacji z 1653 roku na potrzeby niniejszego artykułu niezbędne było opracowanie ujednoliconej tabeli. Dla jej przejrzystości uproszczono pisownię, pomijając zwroty grzecznościowe, takie jak ,pan” (skrót p.), „pani” itp., występujące na początku i niekiedy też w środku wierszy. Rozwinięto skrót „kami.” do „kamienica”. Usunięto też niektóre dopiski zaciemniające całość obrazu oraz wszystkie podsumowania kwot na kolejnych stronach, poza końcową. Dodatkowo jeśli jedna osoba występowała dwukrotnie i istniała pewność, że to ta sama osoba, połączono obie pozycje w jedną. Przykładem mogą być dwie pozycje dotyczące „sirot Mikołaia Pałki” na s. 159; pierwsza dotyczy 1500 złotych (80 złotych do zapłaty), druga 3000 złotych (160 złotych do zapłaty), z dopiskiem „wzglendem kami[enicy]”. W ujednoliconej tabeli dodano te dwie kwoty (łącznie 4500 i 240 złotych do zapłaty). Po takim ujednoliceniu otrzymano 144 wiersze w tabeli.

Wiersze oryginalnego rejestru nie miały żadnego konkretnego porządku; być może deputaci tworzyli wyliczenia według kolejnych ulic w mieście. Przy braku adresów w rejestrze taka hipoteza nie jest jednak w tym miejscu bardzo przydatna. Ważniejsze były same kwoty szacunków, stąd tabelę ułożono od najwyżej do najniżej oszacowanego majątku, czyli od najwyższej do najniższej kwoty do zapłacenia na okup.

W każdym wierszu tabeli pozostawiono cztery z pięciu oryginalnych danych (nazwisko, oszacowanie majątku, kwotę do zapłaty oraz uwagi) ${ }^{30}$. Kolumnę z uwagami ujednolicono do pięciu typów pól: „dał” (czyli cała naznaczona kwota została zapłacona), „nie dał”, „nadpłata” i ,niedopłata”. W oryginale uwagi te były sformułowane bardziej dowolnie, często zawierając kwoty reszty wymaganej do zapłacenia przez daną osobę bądź kwoty do zwrotu tej osobie. Dalej W wierszach tabeli usunięto pozycję z wysokością składki (531/3 złotego od każdego 1000 złotych), ponieważ każdy płacił taki sam procent i nie było potrzeby powtarzać tej danej we wszystkich wierszach.

Dodano natomiast dodatkowe dwie kolumny, które pozwoliły wydobyć więcej danych $\mathrm{z}$ tabeli. W pierwszej dodanej kolumnie podzielono Ormian z listy na trzy grupy: mężczyzn, kobiety i grupy osób o nieokreślonej liczbie bez wyszczególnionych nazwisk (głównie sieroty). W drugiej kolumnie postarano się zidentyfikować osoby występujące w tabeli według informacji zawartych w pierwszej części rękopisu i przypisać te osoby, o ile to było możliwe, do dwóch grup: star-

${ }^{30}$ Zob. Aneks 1; w tabeli z powodu braku miejsca zawarto tylko kolumny z nazwiskami, kwotami oszacowania majątku oraz uwagami. 
szych ormiańskich i pospólstwa. Wprowadzone podziały pozwoliły na dokładniejsze zbadanie rozwarstwienia majątkowego $\mathrm{w}$ gminie.

\section{ANALIZA REJESTRU KOEKWACJI Z 1653 ROKU POD KĄTEM LICZEBNOŚCI I STRUKTURY MAJĄTKOWEJ GMINY ORMIAŃSKIEJ}

Jakie pytania z zakresu demografii historycznej można postawić przy tak skonstruowanej i ujednoliconej tabeli? Z jednej strony kusząca jest perspektywa znalezienia odpowiedzi na pytania dotyczące liczebności gminy, a z drugiej wartościowa wydaje się próba przeprowadzenia analizy struktury społecznej i rozwarstwienia majątkowego w gminie ormiańskiej we Lwowie około połowy XVII wieku.

\section{Liczebność gminy ormiańskiej w 1653 roku}

Podstawowe pytanie demograficzne brzmi: czy na podstawie omawianego rejestru koekwacji można wysnuć wnioski na temat liczebności lwowskiej gminy ormiańskiej? W związku z tym w pierwszej kolejności należy zastanowić się, czy koekwacja dotyczyła wszystkich Ormian w mieście, czy tylko części. Wydaje się, co wynika z samego tytułu dokumentu, że wyrównanie objęło wszystkich członków tzw. nacji ormiańskiej, czyli osoby będące członkami grupy etniczno-religijno-prawnej. Dotyczyło to oczywiście tylko mieszkańców miasta, z pominięciem przedmieść. Rejestr nie dotyczył jednak tylko obywateli płci męskiej z prawem ormiańskim, bo na liście pojawiają się też kobiety (w tym wdowy) i sieroty. Problematyczna jest kwestia uwzględnienia bądź nieuwzględnienia w rejestrze Ormian bez praw miejskich. Deputatom prowadzącym koekwację nie mogło jednak raczej zależeć na pomijaniu kogokolwiek przy zbieraniu składek. Wydaje się, że rejestr objął poza Ormianami na miejscu osoby nieznajdujące się wtedy w mieście, zwłaszcza że duży procent osób na liście ma dopisek „nie dał”. Część z nich mogła nie zapłacić ze względu na nieobecność. Ostatecznie można więc przypuszczać, że lista obejmuje większość Ormian żyjących wtedy we Lwowie, choć nie wszystkich. Jaka mogła być jednak ich przybliżona liczba?

$\mathrm{Na}$ końcu rejestru (s. 165) znajdujemy dopisek kopisty, którego również zastanawiały podobne sprawy. Pisarz ten, pracujący w 1713 roku, miał do dyspozycji zarówno rejestr koekwacji z 1653 roku, jak i rejestry z 1704 roku związane z płaceniem kontrybucji Szwedom. Na podstawie tych dokumentów kopista wysnuł wniosek, że ,in A[nn]o 1653 gospodarzów, wdóf y sirot 147 było w natiey orm[iańskiej]”, a ,in A[nn]o 1704 podczas szwedzkiego wzięcia miasta 73 było natiey orm[iańskiej]". Pierwsza z tych liczb (147), powtarzana zresztą przez niektórych późniejszych badaczy w kontekście liczebności lwowskiej gminy ormiańskiej ${ }^{31}$, nie odzwierciedla jednak z pewnością dokładnie prawdy. Liczba 147 to liczba kwot przypisanych poszczególnym pozycjom w rejestrze. Po ujedno-

${ }^{31}$ M. Zakrzewska-Dubasowa, Ormianie $w$ dawnej Polsce, s. 41. 
liceniu tabeli liczba wierszy wyniosła 144, z powodu połączenia kilku pozycji razem. Jednak i ta liczba nie jest właściwa, ponieważ mamy do czynienia zarówno z pojedynczymi osobami, jak i dwoma i więcej osobami przypisanymi do jednej kwoty.

Trzeba zwłaszcza pamiętać, że pod każdym nazwiskiem Ormianina gospodarza mogły się kryć jeszcze żona i dzieci. Dlatego każdego gospodarza trzeba potraktować jako minimum trzy osoby (nie wszyscy byli żonaci, niektórzy mieli więcej dzieci itd.). Problematyczne są też sieroty, bo nie wiadomo, ile ich mogło być. Trudne do interpretacji liczbowej jest także stwierdzenie „y drudzy”, na przykład „Jakubkowna y drudzy wzglendem kamienicy”. Takie pozycje są w rejestrze na szczęście tylko dwie, stąd policzenie bądź niepoliczenie „drugich” nie zmienia w znaczący sposób całości obrazu. Ogólnie po przeprowadzeniu bardzo przybliżonych szacunków można ocenić liczbę Ormian we Lwowie w tym czasie (mężczyzn, kobiety i dzieci) na około 400 osób. Zagadnienie populacji Lwowa to osobny temat badawczy, ale przyjmując w przybliżeniu, że w połowie XVII wieku Lwów mógł liczyć około 25 000-30 000 mieszkańców, z czego $2 / 3$ żyły na przedmieściach ${ }^{32}$, Ormianie stanowiliby kilka procent mieszkańców Lwowa intra muros.

\section{Struktura społeczno-majątkowa gminy ormiańskiej w 1653 roku}

Oprócz pytania o liczebność Ormian, dane z tabeli można wykorzystać do zbadania struktury społeczno-majątkowej gminy ormiańskiej we Lwowie. Po podsumowaniu wszystkich wierszy można stwierdzić, na jaką sumę oszacowali deputaci łączny majątek Ormian lwowskich: było to 1624625 złotych. Rejestr ogólnomiejski z 1656 roku wykazał natomiast sumę 1277000 złotych dla majątku ruchomego Ormian ${ }^{33}$, co oznaczałoby, że majątek nieruchomy do nich należący oszacowano na około 347625 złotych. Łączny majątek Lwowa (nieruchomości i dobra ruchome) oszacowano w 1656 roku na 5247479 złotych $^{34}$, z czego wynika, że majątek Ormian stanowił około 31\% ogółu. Biorąc pod uwagę szacowaną już wyżej liczebność gminy ormiańskiej, był to wynik godny podziwu.

Licząc po 53 złote 10 groszy od każdego 1000 złotych, łączną kwotą, jaką Ormianie mieliby złożyć na okup, byłoby 86646 złotych 20 groszy. Nie zgadza się to z wpisaną w rękopisie kwotą 91421 złotych 10 groszy z powodu wcześniej wymienionych błędów (zwłaszcza z powodu policzenia dwukrotnie kwoty 4482 złotych). Niezależnie od poprawności obu tych kwot, jeśliby przyjąć, że łączna suma okupu wyniosła 500000 złotych, to Ormianie mieliby zapłacić po wyrównaniu około $17-18 \%$ z tej sumy.

32 Р. Лозинсь кий, Етнічний склад населення Львова (у контексті суспільного розвитку Галичини), Львів 2005, s. 65. L. Podhorodecki podaje, że Lwów w 1661 roku liczył 24100 mieszkańców, zob.: L. Podhorodecki, Dzieje Lwowa, s. 83.

${ }^{33}$ W. Łoziński, Patrycyat i mieszczaństwo lwowskie, s. 169.

${ }^{34}$ Ibidem. 
Pierwszą kwestią, jaka zwraca uwagę po spojrzeniu na rejestr koekwacji, jest ogromne rozwarstwienie majątkowe w obrębie lwowskiej nacji ormiańskiej. $\mathrm{Na}$ szczycie drabiny majątkowej znajdowały się osoby, których zasoby oszacowano na dziesiątki bądź nawet setki tysięcy złotych. W tym aspekcie zwraca uwagę zwłaszcza ogromny majątek Jana Warteresowicza, starszego ormiańskiego i erecpochana, wyceniony na 600000 złotych. Był on nie tylko najbogatszym Ormianinem, ale też mieszczaninem lwowskim w ogóle ${ }^{35}$. Sam Jan Warteresowicz miał wyłożyć zgodnie z przelicznikiem 32000 złotych, a więc ponad 1/3 całej kwoty okupu wyznaczonej dla Ormian. Co więcej, przy tej kwocie widnieje dopisek „dał”, oznaczający, że Jan Warteresowicz rzeczywiście dysponował takimi kwotami (w przeciwieństwie do sytuacji, w której byłby zadłużony).

Drugą osobą w hierarchii majątkowej gminy mógłby być wspominany już Iwaszko Torosowicz alias Wieniawski (później nobilitowany), z tym że jego kwotę oszacowania 125000 złotych wyliczono na podstawie 25000 złotych majątku i 100000 złotych długu. Jeśli pominąć Iwaszkę z tego względu, że większość jego majątku stanowiły zobowiązania, to na drugim miejscu zamiast niego plasuje się Krzysztof Jan Bernatowicz z majątkiem oszacowanym na 80000 złotych. Dalej następuje kilku bogatych kupców, po czym ciekawą pozycję ósmą stanowią „siroty Murada Eminowicza”, z majątkiem oszacowanym na niebagatelne 38000 złotych. Jest to pierwsza pozycja z grupy „,zbiorowych” w tabeli. Z kolei za najbogatszą kobietę (możliwe, że wdowę) należy uznać znajdującą się na pozycji dziewiątej Zachariaszową Manczukiewicową, z majątkiem wycenionym na 28000 złotych.

Po drugiej stronie drabiny znajdują się ludzie o majątku wycenionym poniżej 1000 złotych (300-600 złotych). Łatwo policzyć, że najbiedniejszy Ormianin (a właściwie Ormianka) wciągnięty do rejestru koekwacji miał majątek 2000 razy mniejszy od majątku najbogatszego Jana Warteresowicza. W naszych czasach można by tę różnicę porównać do różnicy pomiędzy człowiekiem z kilkoma tysiącami złotych na koncie a milionerem.

Średnia arytmetyczna dla wszystkich pozycji w kolumnie „Oszacowanie majątku” wynosi około 11282 złote. Po odrzuceniu wartości najwyższych wyraźnie odstających od reszty (600 000 złotych Jana Warteresowicza i 125000 złotych Iwaszki Torosowicza) średnia arytmetyczna wynosi już tylko około 6335 złotych. Z kolei mediana dla tej kolumny wynosi 3000 złotych.

Opracowując wykres obrazujący rozwarstwienie majątkowe w gminie ormiańskiej, podzielono pozycje na liście na cztery grupy: z majątkiem oszacowanym na 300-4999 złotych, 5000-9999 złotych, 10 000-19 999 złotych i powyżej 20000 złotych.

35 Ibidem, s. 170. 


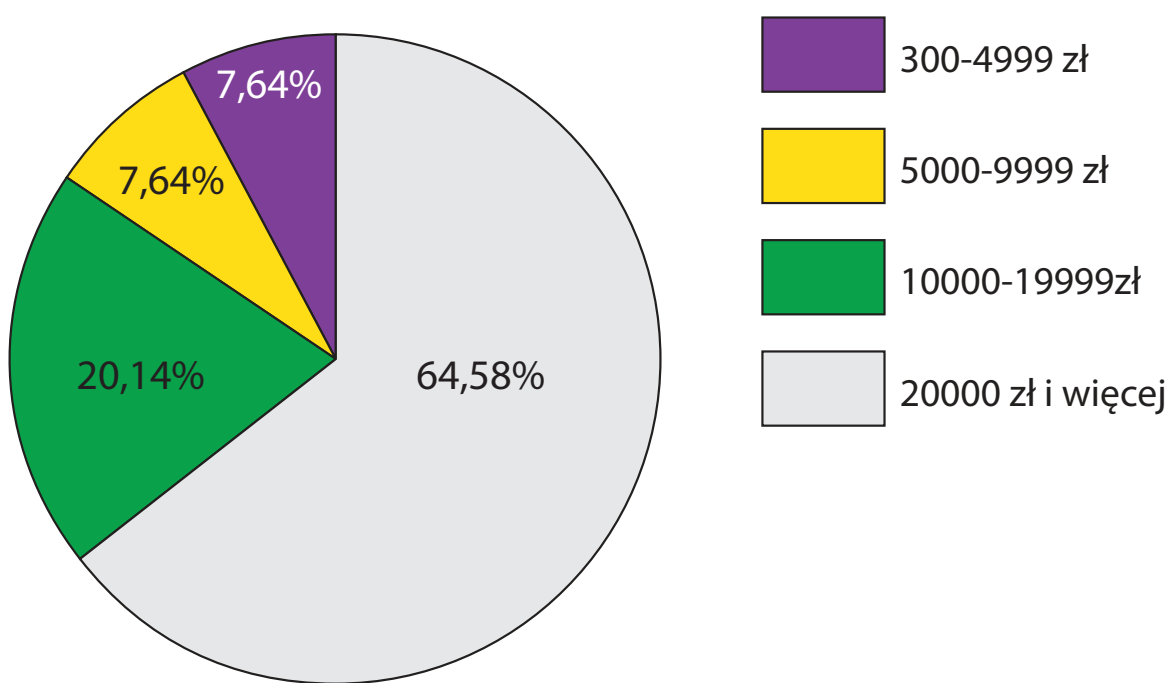

Wykres 1. Rozwarstwienie majątkowe w gminie ormiańskiej we Lwowie w 1653 roku

Dzięki wykresowi widać wyraźnie, że niemal 2/3 członków gminy znajdowało się w grupie wycenionej na mniej niż 5000 złotych, natomiast najbogatsi stanowili około 7\% całości. Z kolei dzięki informacjom zawartym w ujednoliconej tabeli widać też, że 11 najbogatszych osób w gminie dysponowało $2 / 3$ całego wycenionego majątku.

Z listy koekwacji łatwo jest wyliczyć indeks Giniego dla gminy ormiańskiej. Wynosi on w przybliżeniu 0,78 dla wszystkich pozycji i 0,63 , jeśli pominąć Jana Warteresowicza i Iwaszkę Torosowicza. W obydwu wypadkach taki poziom indeksu oznacza ogromną koncentrację majątku w rękach nielicznej grupy bogaczy. Aby porównać ten poziom koncentracji z ogółem mieszkańców Lwowa, należałoby powtórzyć obliczenia z wykorzystaniem ogólnomiejskich rejestrów koekwacji.

\section{MAJĄTEK POSZCZEGÓLNYCH GRUP W GMINIE W 1653 ROKU}

\section{Starsi ormiańscy}

Rozpatrując majątek poszczególnych grup społecznych, wypada zacząć od starszych ormiańskich. W rejestrze znajdujemy, zgodnie z oczekiwaniami, wszystkich 12 starszych występujących na prawdopodobnie wcześniejszej niż rejestr liście z 19 lutego 1653 roku (s. 36). Brakuje co prawda Gabriela Kaprusiowicza, ale jest Krzysztof Kaprusiowicz (wymieniony zresztą dwukrotnie), który być może jest tą samą osobą co Gabriel. Domniemanie to bierze się stąd, że w części pierwszej rękopisu pod nazwiskiem Kaprusiowicz występuje tylko i wyłącznie Gabriel, ponadto trudno wyobrazić sobie sytuację, w której jeden ze starszych zostałby z niewiadomych przyczyn pominięty przy rozliczeniach. Zdarzało się zresztą, że ta sama osoba występowała pod dwoma imionami lub patronimikami. Na liście nie został uwzględniony w osobnej pozycji (nie ma 
oszacowania jego majątku) jeden ze starszych - Jan Krzysztofowicz, jednak jego nazwisko pojawia się na liście razem z Krzysztofem J. Bernatowiczem.

Z 12 starszych ormiańskich 11 (poza Krzysztofem Zadikowiczem/Zadikiewiczem) pojawia się na samym początku rejestru (s. 156-157), co oznacza, że deputaci zaczęli rozliczenie od samych siebie i swoich kolegów. Warto pamiętać, że w komisji deputatów prowadzących rejestr było 4 starszych i 6 ,,pospolitych”. Wyodrębniając z tabeli ogólnej samych starszych, możemy dojść do kilku wniosków. Oszacowanie ich majątków waha się od kilku do kilkuset tysięcy złotych. Niektórzy z nich znajdowali się więc w najniższej grupie majątkowej, a inni byli na samym szczycie. Uderza zwłaszcza fakt, że erecpochan ,pierwszy” Krzysztof A. Zachnowicz miał majątek wyceniony na 3000 złotych, podczas gdy majątek erecpochana „drugiego” Jana Warteresowicza został wyceniony na 600000 złotych. Ta różnica majątkowa między dwoma starszymi nie pasuje do obrazu, zgodnie z którym $\mathrm{w}$ radzie starszych zasiadali wyłącznie Ormianie z najbogatszych rodzin ${ }^{36}$. Podobnie przeczy temu wyobrażeniu fakt, że wiele osób z pospólstwa dysponowało większymi majątkami niż starsi. Spośród 20 najbogatszych osób w gminie w 1653 roku tylko sześć należało do rady starszych (dodatkowe cztery zostały wybrane na starszeństwo w późniejszym okresie).

\begin{tabular}{|l|c|c|l|}
\hline \multicolumn{1}{|c|}{ Nazwisko } & $\begin{array}{c}\text { Oszacowanie } \\
\text { majątku (zł) }\end{array}$ & $\begin{array}{c}\text { Kwota } \\
\text { do zapłaty }\end{array}$ & \multicolumn{1}{|c|}{ Uwaga } \\
\hline [Jan] Warteresowicz erespochan 2 & 600000 & 32000 & dał \\
\hline $\begin{array}{l}\text { Krzysztof J. Bernatowicz, reszty przy [Janie] } \\
\text { Krzysztofowiczu }\end{array}$ & 80000 & 4482 & dał \\
\hline $\begin{array}{l}\text { Krzysztof Bernatowicz [Krzysztof A. Bernato- } \\
\text { wicz] }\end{array}$ & 40000 & 2133 & nadpłata \\
\hline Szymon Steckiewicz & 20000 & $1066^{2} / 3$ & dał \\
\hline Krzysztof Zadikowicz & 16000 & $853^{1 / 3}$ & niedopłata \\
\hline $\begin{array}{l}\text { Grzegorz Der Łukaszewicz z Łukaszewicza zię- } \\
\text { ciem }\end{array}$ & 12000 & 640 & dał \\
\hline Mikołay Domażyrski & 7000 & $373^{1 / 3} 3$ & dał \\
\hline Krzysztof Iwaszko Łyskiewicz & 5000 & 266 & dał \\
\hline Krzysztof A. Zachnowicz erespochan 1 & 3000 & 160 & nie dał \\
\hline Krzysztof Piotrowicz & 3000 & 160 & nie dał \\
\hline Krzysztof Kaprusiewicz & 2000 & $106^{2} / 3$ & nie dał \\
\hline $\begin{array}{l}\text { Krzysztof Kaprusiewicz [możliwe, że dwukrot- } \\
\text { nie ten sam] }\end{array}$ & 500 & $261 / 2$ & nie dał \\
\hline
\end{tabular}

Tabela 4. Starsi ormiańscy w rejestrze koekwacji z 1653 roku

${ }^{36}$ K. Stopka, Ormianie w Polsce, s. 29. 


\section{Pospólstwo}

Wyodrębnienie grupy starszych ormiańskich piastujących stanowiska w 1653 roku nie było problematyczne dzięki składowi rady z tego roku, podanemu na s. 36 rękopisu. Większym problemem była identyfikacja osób należących do pospólstwa. Wiadomo oczywiście, że musieli to być mężczyźni, jednak identyfikacja wprost na podstawie pierwszej części rękopisu była możliwa tylko w nielicznych przypadkach, głównie w odniesieniu do Ormian, którzy w późniejszym okresie zostali wybrani spośród pospólstwa do rady starszych (i stąd wiadomo na pewno, że wcześniej należeli do pospólstwa). W odniesieniu do reszty mężczyzn nie jest pewne, że byli oni zaliczeni do pospólstwa, gdyż niewykluczone, że rejestr objął też osoby bez praw miejskich.

Gdyby przyjąć, że rejestr objął też mężczyzn bez praw miejskich, należałoby się spodziewać, że ewentualne osoby zaliczone do „plebsu ormiańskiego” znalazłyby się w najuboższej kategorii w rejestrze. Okazuje się jednak, że najniżej uposażony Ormianin, o którym wiadomo na pewno, że należał do pospólstwa (Zachariasz Hołubowicz Bazarczyk), miał majątek wyceniony na 2000 złotych, czyli był niedaleko końca listy. Wydaje się, że w takiej sytuacji bezzasadne jest wyodrębnianie dodatkowej, niewystępującej w źródle, kategorii ,plebsu ormiańskiego".

\section{Stosunek sumy majątków poszczególnych grup do ich liczebności w 1653 roku}

Ostatecznie przy tworzeniu wykresu obrazującego stosunek liczebności poszczególnych grup w gminie ormiańskiej do sumy wyceny ich majątków zdecydowano się wyodrębnić kilka kategorii. Osobno potraktowano osobę Jana Warteresowicza z powodu jego ogromnego majątku, którego nie sposób było dodać do reszty wycen z grupy rady starszych bez zaburzenia obrazu całości. Następne grupy to: pozostali starsi, pospólstwo (zawierające być może też osoby bez praw miejskich), kobiety występujące pojedynczo (część z nich to prawdopodobnie wdowy), wreszcie kilkanaście pozycji zawierających więcej niż jedną osobę (w przeważającej części - sieroty).

Średnia wycena majątku dla poszczególnych grup wynosi w zaokrągleniu: starsi bez Jana Warteresowicza - 17000 złotych, pospolici - 7000 złotych, sieroty -7000 złotych, kobiety -4500 złotych. Trzeba jednak pamiętać, że pozycje z grupy sierot zawierają co najmniej dwie osoby, więc rzeczywista średnia musi być co najmniej dwukrotnie niższa (3500 złotych). W tym zestawieniu starsi wypadają jako najbogatsza grupa $\mathrm{w}$ gminie, co wynika, jak pokazano, nie $\mathrm{z}$ ich ogólnego bogactwa, a z zamożności kilku osób z samej góry drabiny majątkowej. Sieroty w takim ujęciu wypadają jako najbiedniejsza grupa. 


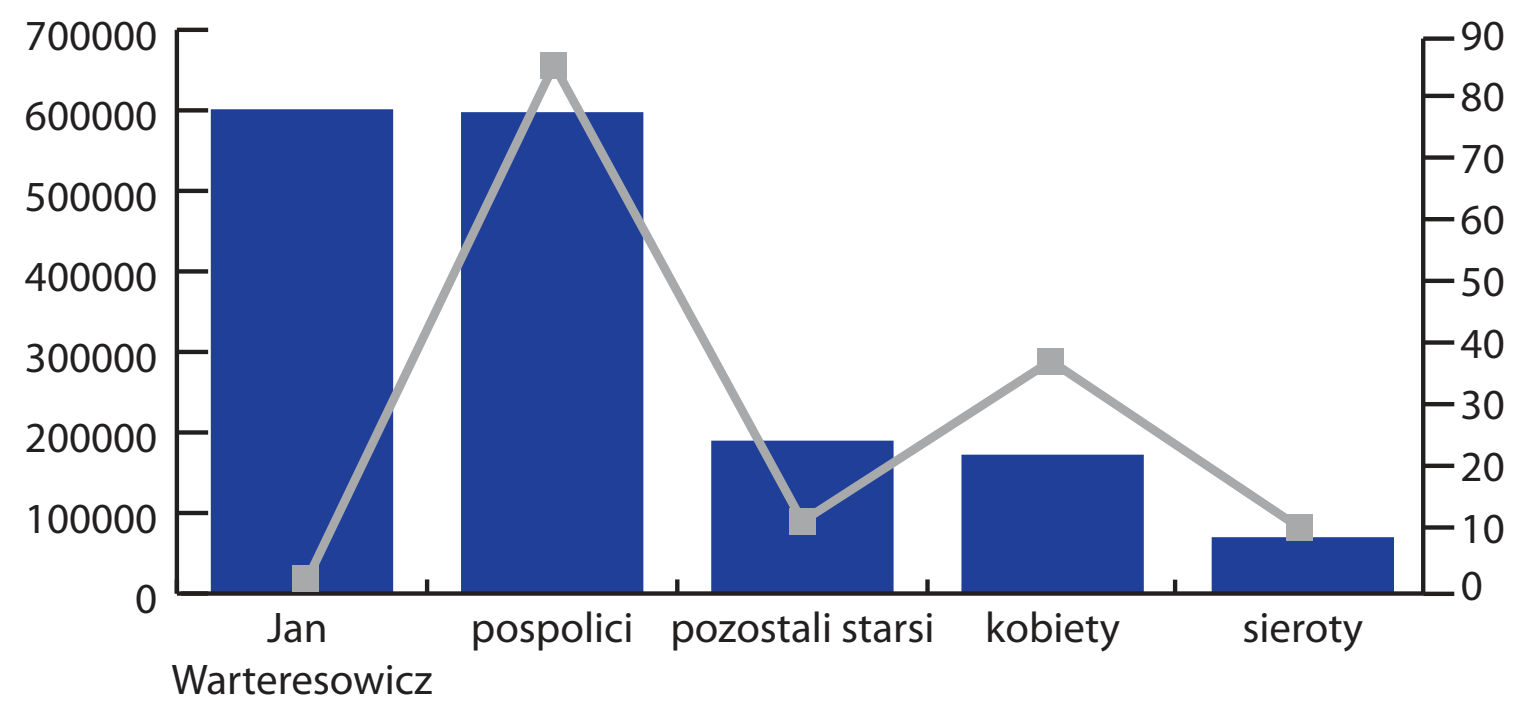

oszacowanie majątku (zł)

- liczebność

Wykres 2. Majątek a liczba osób w gminie w 1653 roku

\section{POZIOM SKUTECZNOŚCI KOEKWACJI Z 1653 ROKU}

Rozważania na temat rejestru koekwacji z 1653 roku zostaną zakończone zbadaniem ostatniej kolumny w tabeli, czyli uwag na temat tego, kto dał, a kto nie dał wyznaczonych mu sum. Ta kolumna tabeli obrazuje poziom skuteczności deputatów w ściąganiu należności. Trzeba pamiętać, że części osób z listy mogło nie być wtedy w mieście i zapłaciły później, jednak można przypuszczać, że większość osób nie zapłaciła z innych przyczyn. Jak wspomniano, mamy tu cztery grupy osób: te, które dały całą kwotę, te, które nie dały nic, te, które dały część kwoty (niedopłata), i te, które dały za dużo (nadpłata). Przy niektórych nazwiskach nie ma żadnych uwag.
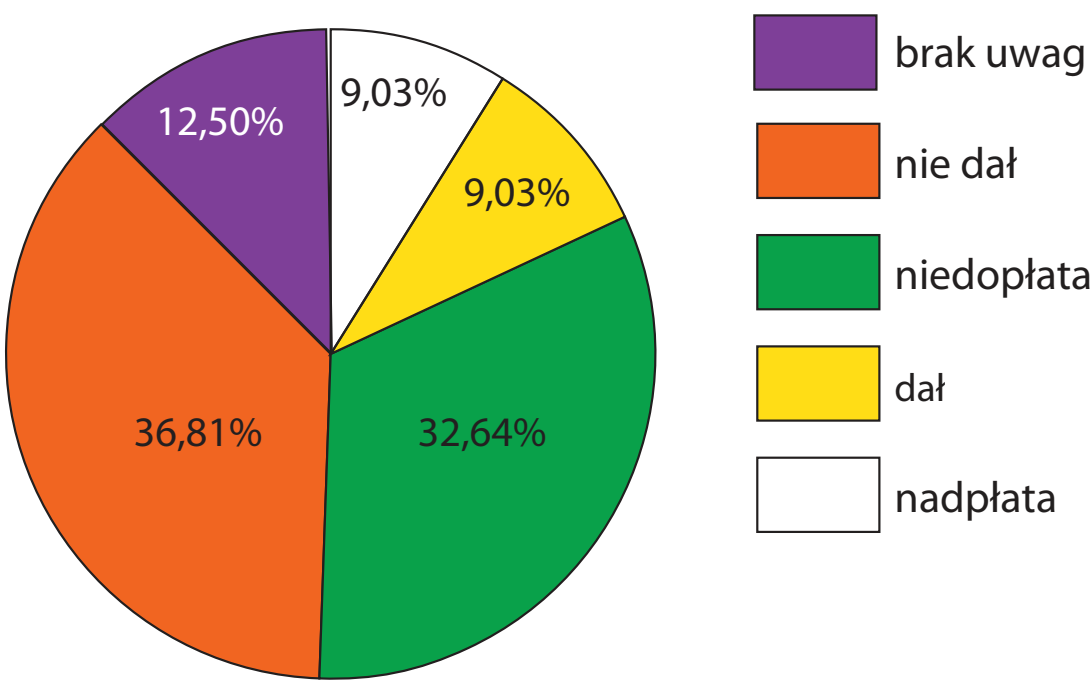

Wykres 3. Efekty koekwacji z 1653 roku 
Jak widać, przynajmniej 70\% osób na liście nie dało nic z kwot im przypisanych bądź też nie dało wszystkiego. Z drugiej strony $18 \%$ dało całą kwotę lub więcej. Nie wiadomo przy tym, czy osoby, przy których nie ma żadnych uwag, dały pieniądze. Te osoby znajdują się głównie na przedostatniej stronie rejestru, co sugeruje, że w momencie powstania rejestru nie zostały wcale rozliczone, a więc można je doliczyć do grupy niepłacących.

Z powyższego wykresu wyłania się obraz walki mniejszej grupy osób o odzyskanie pieniędzy od większej grupy. Tak też było zapewne w przypadku wyrównania ogólnomiejskiego. Z tabeli nie wynika jednoznacznie, że to bogaci nadpłacili, a biedni nie, ponieważ nadpłaty zdarzają się też wśród uboższych członków gminy. Trzeba jednak zwrócić uwagę na fakt, że jeśli posortujemy tabelę od najbogatszych do najbiedniejszych, to pierwsza osoba, która w ogóle nic nie dała, znajduje się dopiero na 30. pozycji, w grupie z majątkiem wycenionym pomiędzy 5000 i 9999 złotych. Warto przy pomocy tabeli przyjrzeć się, czy istnieje związek pomiędzy bogactwem i faktem zapłacenia bądź niezapłacenia wyznaczonych sum. W tabeli pominięto te nazwiska, przy których nie było żadnych uwag, stąd łączna liczba osób wynosi 126.

\begin{tabular}{|l|c|c|c|c|c|}
\hline Oszacowanie majątku (zł) & Nadpłacił & Dał & Niedopłacił & Nie dał & Ogółem \\
\hline $300-4999$ & 7 & 5 & 20 & 47 & 79 \\
\hline $5000-9999$ & 4 & 3 & 13 & 6 & 26 \\
\hline $10000-19999$ & 1 & 1 & 9 & 0 & 11 \\
\hline 20000 i więcej & 1 & 4 & 5 & 0 & 10 \\
\hline Ogółem & 13 & 13 & 47 & 53 & 126 \\
\hline
\end{tabular}

Tabela 5. Zapłata sum z koekwacji z 1653 roku według grup majątkowych

Wśród dwóch najbogatszych grup nie znalazły się osoby, które w ogóle niczego nie zapłaciły. Natomiast w najniższej grupie majątkowej niemal $60 \%$ nie dało deputatom ani grosza. Potwierdza się więc teza, że to bogaci złożyli się na okup dla Chmielnickiego i Tuhaj beja, a następnie próbowali odzyskać przynajmniej część tych sum od biedniejszej części gminy. Co prawda, kilka osób z najniżej oszacowanej grupy też nadpłaciło na okup i inne obciążenia, jednak mając w pamięci różnice majątkowe, wiemy, że te nadpłaty wynosiły jedynie po kilkadziesiąt złotych, podczas gdy sam Krzysztof Awedik Bernatowicz dał według dopisku przy jego nazwisku 8676 złotych, a więc o 6543 złotych więcej niż powinien (jego majątek oszacowano na 40000 złotych).

\section{PoDSUMOWANIE BADANIA REJESTRU KOEKWACJI Z 1653 ROKU}

Przeprowadzone dotychczas badania pozwalają na wyciągnięcie kilku wniosków. W sferze pytań z dziedziny demografii historycznej można stwierdzić, że gmina ormiańska we Lwowie (bez przedmieść) około połowy XVII wieku nie była liczna, jednak jej majątek w stosunku do majątku wszystkich mieszczan 
przedstawiał się imponująco: około $1 / 3$ całego majątku miasta należała do Ormian, którzy stanowili zaledwie kilka procent mieszkańców.

Rozwarstwienie majątkowe w obrębie samej gminy ormiańskiej było bardzo duże. Najbogatszy z rady starszych Jan Warteresowicz dysponował majątkiem oszacowanym na 600000 złotych, podczas gdy najbiedniejszego starszego wyceniono na 2500 złotych. Z kolei najbogatszy Ormianin z pospólstwa Krzysztof Wartanowicz miał majątek szacowany na 55000 złotych, a majątek najbiedniejszego z (prawdopodobnie) pospólstwa Mikołaja Zadikowicza szacowano na 500 złotych. Spośród wdów najbogatsza była Zachariaszowa Manczukiewicowa (28 000 złotych), a najbiedniejsza Janowa Moskiefka (300 złotych). Z kolei najbogatsze sieroty (sieroty Murada Eminowicza) mogły dysponować majątkiem w wysokości 38000 złotych, a najbiedniejsze (sieroty Harburaszowi bądź Harburaszowe) miały 600 złotych.

Ciekawym wynikiem analizy rejestru z 1653 roku jest stwierdzenie, że starsi ormiańscy, oprócz Jana Warteresowicza, nie różnili się znacząco od pospólstwa w kwestiach majątkowych. Wielu ,pospolitych” było bogatszych od niektórych starszych. Również nie wszystkie osoby wybrane spośród pospólstwa na starszeństwo w późniejszym okresie należały do najbogatszych Ormian.

Ostatnim wnioskiem z badania rejestru z 1653 roku jest potwierdzenie przypuszczenia, że podczas oblężenia w 1648 roku to bogaci Ormianie złożyli się na okup w towarach, klejnotach i gotówce, a następnie próbowali odzyskać część straconych sum od biedniejszej części gminy.

CIĄG DALSZY KOEKWACJI - REJESTR Z 1656 ROKU I DOKUMENT Z 1657 ROKU Jak się potoczyła dalej sprawa koekwacji z miastem, można się dowiedzieć z dokumentu zawartego na s. 59-64 omawianego rękopisu (a więc w części pierwszej źródła). Dokument z datą 10 marca 1657 roku składa się z dwóch części. Pierwsza dotyczy relacji danej radzie starszych przez deputatów, druga to „tenor porachowania" z 26 grudnia 1656 roku, przedstawiony radzie przez tychże deputatów. Deputaci zostali wysłani w celu odzyskania pieniędzy nadpłaconych przez Ormian na okup z 1648 roku. Akcja miała się odbyć w ramach ogólnomiejskiej koekwacji (która odbyła się w 1656 roku, chociaż się wówczas nie zakończyła). Deputaci ormiańscy (starsi ormiańscy Krzysztof A. Bernatowicz, Krzysztof Zadikiewicz i Jan Iwaszko Torosowicz) przejrzeli wspólnie z deputatami ogólnomiejskimi dokumenty dotyczące osób, które nadpłaciły (zwanych w piśmie „,iniuriatami”, czyli „niesprawiedliwie potraktowanymi”), i na tej podstawie stworzyli rejestr Ormian, którym należą się jeszcze pieniądze od miasta.

Z wyliczeń deputatów wynikało, że miasto jest winne Ormianom 42646 złotych $^{37}$, przy czym 11816 złotych zostało już potrącone zainteresowanym osobom

${ }^{37}$ Niektórzy badacze (S. Barąc z, Rys dziejów ormiańskich, s. 122) błędnie uważali, że kwota ta przedstawia sumę wkładu Ormian w okup z 1648 roku. Myląca jest konstrukcja zda- 
na nieruchomościach (czyli prawdopodobnie z zadłużenia w stosunku do miasta), co zostawiło do rozliczenia kwotę 30810 złotych. Ta kwota znajduje się też w podsumowaniu listy osób na s. 64 .

\section{Opis rejestru z 26 grudnia 1656 roku (wpisanego pod dokumentem z 10 marca 1657 roku)}

Lista osób na s. 61 zaczyna się od podania charakteru dokumentu (,tenor porachowania”) oraz tytułu: „Porachowanie, którym osobom płacić się ma z coaequatiey generalney od miasta, którym iusz z dóbr stoiących defalkowało się przez pp. deputaty". Po nim następuje wyliczenie zawierające 50 pozycji, w tym 48 pojedynczych nazwisk, grupę osób (Wartanczykowie) oraz pozycję „Do skrzynki” (chodzi tu o skarbonę bractwa religijnego ormiańskiego). Przy każdej pozycji jest wpisana kwota w złotych należna od miasta.

Spośród 48 pojedynczych osób na liście 16 nie występowało w rejestrze z 1653 roku, co świadczy o tym, że wcześniejszy o kilka lat rejestr nie zawierał nazwisk wszystkich Ormian lwowskich. Te 16 osób musiało być z pewnością we Lwowie w 1648 roku, skoro dotyczyła ich sprawa wyrównania kwot danych na okup; nie można więc zakładać, że przybyły do Lwowa po 1653 roku. Ta uwaga nie powinna jednak zmienić $\mathrm{w}$ diametralny sposób wcześniejszych, i tak już bardzo przybliżonych, szacunków liczebności lwowskiej gminy ormiańskiej.

Niestety rejestr z 1656 roku zawiera zbyt mało informacji, by móc przeprowadzić podobne badania co w przypadku rejestru z 1653 roku. Po pierwsze zawiera dane odnośnie do mniejszej liczby osób, po drugie jest to rejestr kwot, które miasto było winne Ormianom, w związku z czym nie można na tej podstawie przeprowadzić badań rozwarstwienia majątkowego ani liczebności gminy ormiańskiej we Lwowie. Grupą łatwo identyfikowalną w tym dokumencie (na podstawie innych wpisów) są starsi ormiańscy (na liście jest ich 9 spośród 12), jednak i tu nie można wysnuć wielu wniosków poza tym, że większość spośród starszych domagała się zwrotu pieniędzy od miasta.

\section{REJESTR Z 1656 ROKU A KOEKWACJA OGÓLNOMIEJSKA}

$\mathrm{W}$ omawianym dokumencie jest jednak jeden zastanawiający wątek. Jeśli przyjrzeć się 32 osobom, które znalazły się w obu rejestrach: z 1656 i z 1653 roku, można zauważyć pewną niezgodność. Tylko 4 osoby spośród nich dały za dużo na okup według rejestru z 1653 roku, co oznacza, że reszta w 1656 roku powinna

nia na s. 60 zawierającego tę kwotę, jednak ostatecznie wynika z niego, że to właśnie miasto miało oddać 42626 złotych Ormianom, a nie na odwrót: „Pokazało się tedy, że summa od natiey naszey do miasta dana iusz moderowana fl. 42626 u miasta zostawa, z którey różnym osobom niżey opisanym $\mathrm{z}$ dóbr stoiących potrącona iest iusz summa fl. 11816 tym to pp. iniuriatom. A zostawa ieszcze u miasta do dalszey coaequatiey onymże fl. 30810". Poza tym z rejestru z 1653 roku wiemy, że Ormianie mieli dać na okup ponad 90000 złotych. 
być już „usatysfakcjonowana”. Tymczasem pozostałe 28 osób również domagało się zwrotu pieniędzy od miasta. Na jakiej podstawie?

Możliwe są dwie hipotezy. Po pierwsze należy pamiętać, że w 1655 roku doszło do drugiego oblężenia miasta skutkującego drugim okupem, chociaż w dokumencie nigdzie nie stwierdzono, że do wyrównania doliczono kwoty za drugi okup. Po drugie można by przypuszczać, że Ormianie podali miastu inne rejestry rozliczeń niż te, których używali między sobą, przykładowo zaniżając wyceny swoich majątków. Ta druga hipoteza, którą zdają się sugerować kwoty podane przez Władysława Łozińskiego ${ }^{38}$ w kontekście Ormian i koekwacji ogólnomiejskiej, wymagałaby jednak dalszych badań na rękopisie miejskiego wyrównania z 1656 roku. Trudno też w końcu nie podejrzewać, że przez prawie 10 lat od oblężenia z 1648 roku w rozmaitych rejestrach i wyliczeniach nie znalazły się kwoty związane z różnymi pomniejszymi sprawami, zmieniające ostateczną wysokość sum, których Ormianie domagali się od miasta.

Jak widać, proces koekwacji ciągnął się latami i można sądzić, że trwał jeszcze długo po 1657 roku, o ile w ogóle kiedykolwiek został zakończony. Rada starszych w tym samym dokumencie z 1657 roku ogłosiła, że każdy Ormianin $\mathrm{z}$ listy może dochodzić wymienionych sum u władz miasta jako własnego, prywatnego długu. Oznacza to, że rada starszych jako przedstawicielstwo nacji prawdopodobnie nie chciała już w tej sprawie nic więcej robić.

\section{REJESTRY KWOT WYDANYCH NA OKUP DLA SZWEDÓW w 1704 ROKU}

Rejestry z 1704 roku to cztery dokumenty, przy czym najdłuższy jest ten na s. 185-194. Następny dokument dotyczący tego okupu znajduje się na s. 199, kolejny na s. 200-201, wreszcie czwarty, zawierający kwoty oddane lub wyznaczone do oddania Szwedom przez samych Ormian, jest wpisany na s. 202-203. Wszystkie te rejestry wpisano jedną ręką kopisty działającego w 1704 roku lub niedługo później (do 1713 roku). Pismo jest dosyć wyraźne, choć pisarz na każdej stronie wychodził poza prostokątne obramowanie i nie stosował żadnych linii. Dane najczęściej są wpisane w dwóch kolumnach.

\section{OPIS REJESTRU OGÓLNOMIEJSKIEGO Z 1704 ROKU}

Pierwszy rejestr z 1704 roku jest opatrzony datą dzienną 7 września 1704 roku, czyli dwa dni po zdobyciu Lwowa przez Szwedów. Tytuł dokumentu brzmi: „Taxa miasta Lwowa podczas wzięcia przez szturm z piątku na sobotę od woyska króla JM szwedzkiego, na którą zezwolił stan duchowny y świecki, okupując zdrowia y kościoły y świeckie fortuny". Z tytułu dowiadujemy się, że szturm został przeprowadzony z piątku na sobotę (5 na 6 września), czyli 7 września była niedziela.

38 W. Łoziński, Patrycyat i mieszczaństwo lwowskie, s. 169-170. 
Pod tytułem następuje wyliczenie (w dwóch kolumnach) osób i instytucji z przypisanymi do nich kwotami (łącznie 298 pozycji). Kwoty wyrażono w talarach bitych. W pierwszej kolejności wyliczone są osoby z hierarchii duchownej wszystkich wyznań oraz kościołów, cerkwi, zgromadzeń zakonnych i szpitali. Sumy przypisane do osób i instytucji kościelnych w dalszej części rękopisu nazywane są „sumami kościelnymi”. Dalej w rejestrze pojawiają się sumy przypisane do skarbu królewskiego i zamkowego. Następnie pojawiają się kwoty przypisane do całych grup etniczno-religijno-prawnych, czyli Żydów, Greków i Ormian „orientalnych” oraz Szkotów. Po nich następuje długa lista mieszczan lwowskich, w tym Ormian. Kończy się ona na s. 191, po czym kopista przepisał dwie strony podpisów świadków z oryginalnego dokumentu. Kolejne, krótkie wyliczenia, jak również pierwsze podsumowanie „taksy” znajdują się na s. 193194. Podsumowanie „taksy” informuje o wysokości sumy okupu naznaczonej przez Szwedów - 300000 talarów bitych. Krótkie wyliczenia natomiast dotyczą „profugów” („,uciekinierów”) oraz cechów miejskich.

W rejestrze oprócz kwoty końcowej znajdują się cząstkowe podsumowania według kategorii płacących (na przykład kwoty „kościelne”, mieszczanie). W części rejestru dotyczącej mieszczan każda kolumna zaczyna się od podsumowania poprzednich kwot, a kończy sumą kwot z tej kolumny i wszystkich poprzednich. Dzięki temu łatwiej było dostrzec dwa błędy znajdujące się w rejestrze. Poważniejszy z nich znajduje się w drugiej kolumnie na s. 189, w środku listy kwot przypisanych mieszczanom lwowskim ${ }^{39}$. Suma na początku kolumny (czyli łączna kwota od początku rejestru mieszczan) wynosi tam 25775 talarów, a końcowe podsumowanie to 31395 talarów, czyli suma kwot w tej kolumnie powinna wynieść 5620 talarów. Tymczasem z podsumowania wynika, że dolna suma powinna wynieść 40935 talarów, czyli 9540 talarów więcej niż w rejestrze. Nie wiadomo, kto popełnił błąd, ale podejrzewać należy raczej, że znajdował się on już w oryginalnym rejestrze. Jeżeli tak rzeczywiście było, to konsekwencją obu pomyłek musiało być wyznaczenie mieszczanom wyższej niż oczekiwana kwoty do zapłaty. W przypadku mieszczan dążono do uzyskania równej kwoty 42000 talarów ${ }^{40}$, a suma rzeczywiście im przypisana wyniosła 51640 talarów.

Ponieważ w ujednoliconej tabeli na podstawie tego rejestru będą tylko dwie kolumny (nazwa osoby/osób bądź instytucji i kwota do niej przypisaną), pojawia się pytanie, jaki charakter miały kwoty przypisane do kolejnych pozycji na liście. W celu lepszego zrozumienia charakteru „taksy” z 1704 roku warto cofnąć się jeszcze do rejestru koekwacji z 1653 roku.

39 Drugi błąd znajduje się w podsumowaniu pierwszej kolumny na s. 190, jednak w tym wypadku było to ,jedynie" 100 talarów.

${ }^{40} \mathrm{Na}$ s. 191 skreślono nawet zero w przedostatniej kwocie rejestru mieszczan (10 talarów) i poprawiono je na 1 (11 talarów), by łączna kwota przypisana mieszczanom wyniosła równo 42000 talarów. 


\section{PORÓWNANIE REJESTRÓW Z 1653 I 1704 ROKU}

Przy porównywaniu obu rejestrów w pierwszej kolejności trzeba sobie zdać sprawę z ich odmiennego charakteru. Rejestr z 1653 roku był elementem procesu wyrównywania obciążeń poniesionych przez samych Ormian na okup z 1648 roku, natomiast rejestr z 1704 roku powstał w momencie nakładania kwoty okupu na miasto przez Szwedów i dotyczył wszystkich mieszkańców miasta i przedmieść. Być może istniał podobny rejestr stworzony podczas oblężenia w 1648 roku, ale nie jest on zawarty w omawianym rękopisie.

$\mathrm{Na}$ marginesie można zaznaczyć, że sytuacja, w jakiej powstawał rejestr z 1704 roku, była zgoła odmienna od sytuacji w 1648 roku. Po pierwsze w 1648 roku płacono wojskom oblegającym miasto, a nie zdobywcom, którzy dodatkowo plądrowali Lwów i przedmieścia od dnia zdobycia miasta. Można więc przypuszczać, że rok 1648 nie był aż tak wyniszczający dla Lwowa jak rok 1704. Poza tym ustalenie kwot okupów z 1648 i 1655 roku odbyło się na drodze negocjacji w obozie wroga, prowadzonych między innymi przez Ormian. W 1704 roku nie było żadnych negocjacji, suma kontrybucji została narzucona z góry przez najeźdźców.

Rejestr z 1704 roku z jednej strony zawiera więcej pozycji, z drugiej strony wydaje się jednak, że nie można $\mathrm{z}$ niego wyciągnąć aż tyle informacji na temat gminy ormiańskiej co z wcześniejszego rejestru. Podczas gdy w rejestrze z 1653 roku w każdym wierszu jest aż pięć danych (nazwisko, oszacowanie majątku, procent majątku do wyliczenia kwoty do zapłaty, sama kwota do zapłaty oraz uwagi), w taksie z 1704 roku są tylko dwie informacje: nazwisko/nazwiska bądź nazwa instytucji oraz przypisana do danej pozycji kwota.

Rzeczone kwoty przypisane kolejnym pozycjom w rejestrze z 1704 roku mogłyby, wzorem innych rejestrów, oznaczać oszacowanie majątków kolejnych osób i instytucji, kwoty zapłacone bądź kwoty do zapłaty. Interpretację tych kwot jako oszacowania majątków można od razu wykluczyć, ponieważ sumują się w niemal 300000 talarów bitych wyznaczonych do zapłaty przez Szwedów, czyli Szwedzi musieliby zabrać mieszkańcom Lwowa wszystko, co mieli (co zresztą w pewnym sensie uczynili, ale nie tylko przez okup). Pozostaje więc pytanie: czy kwoty te reprezentują sumy naznaczone do zapłaty, czy rzeczywiście opłacone?

Wydaje się, że był to rejestr kwot do zapłaty. Po pierwsze, co widać w bilansach i rejestrach na kolejnych stronach rękopisu, Żydzi ostatecznie zapłacili kwotę znacznie niższą niż ta, która została im wyznaczona. Po drugie całą sytuację opisuje szczegółowo ks. Jan Tomasz Józefowicz w swoim Lwowie utrapionym ${ }^{41}$. Po trzecie niedawno odczytany i przetłumaczony z języka ormiańskiego diariusz autorstwa prawdopodobnie arcybiskupa ormiańskiego Wartana Hunaniana

41 J. T. Józefowicz, Lwów utrapiony in anno 1704 albo Dyjaryjusz wziętego Lwowa przez króla szwedzkiego Karola XII die 6 mensis Septembris anno 1704, Kraków 2003, s. $120 \mathrm{i} \mathrm{n.}$ 
potwierdza przekaz Józefowicza, świadczący o tym, że jeden ze zdobywców Lwowa, generał Stenbock, kazał władzom miejskim i duchowieństwu zgromadzonym na ratuszu podzielić wyznaczoną kwotę okupu w wysokości 300000 talarów (w diariuszu ,guruszy”) pomiędzy mieszkańców Lwowa. Wyznaczenie arcybiskupowi ormiańskiemu kwoty do zapłaty w wysokości 1000 talarów (,guruszy") skłoniło go do ucieczki z miasta ${ }^{42}$. Kwota ta zgadza się z przypisaną do pozycji „Prze. Im. X. Arcybiskup orm.” w omawianym rejestrze, co potwierdzałoby informacje przekazane przez Hunaniana w diariuszu.

Biorąc pod uwagę fakt, że rejestr zawiera kwoty do zapłaty, trudno na jego podstawie stwierdzić, jaką część z wyznaczonych 300000 talarów miasto ostatecznie wypłaciło Szwedom. Oczywiście żeby oszacować łączne straty Lwowa w tym roku, do kwoty kontrybucji należałoby doliczyć też wszystko, co Szwedzi ukradli bądź zniszczyli od zdobycia miasta. Niemniej nie można na podstawie omawianego rejestru stwierdzić z całą pewnością, że dana osoba z listy zapłaciła przypisaną jej kwotę, co potwierdza przykład arcybiskupa Hunaniana, który uciekł z miasta. Niemniej kwota ta mogła zostać zrabowana w inny sposób.

Szwedzi sterroryzowali więc władze Lwowa i kazali im podzielić nałożoną na miasto kwotę kontrybucji. W jaki jednak sposób dzielono tę kwotę i wyznaczano sumy do zapłaty poszczególnym osobom i instytucjom? Trudno podejrzewać, żeby przy tym wyliczeniu stosowano jakiś przelicznik podobny do tego z 1653 roku (53¹/3 złotego od 1000 złotych majątku). Przede wszystkim nie było czasu na szacowanie majątku, całe wyliczenie i zapłata kontrybucji miały się przecież odbyć w ciągu kilku dni, podczas gdy wyrównanie po 1648 roku ciągnęło się latami. Ponadto gdyby wyliczenie kwot do zapłaty miało się odbywać według procentu od majątku, nie byłyby one wyrażone w pełnych talarach, tylko z cząstkami, tak jak w rejestrze z 1653 roku. Wydaje się więc, że kwoty do zapłaty na okup zostały wyznaczone przez przerażone władze miejskie i duchowieństwo

42 „W niedzielę [Szwedzi] złupili także przedmieście, w tym i klasztor nasz, i zrabowali pozostałe mienie. Generał Stenbock, mąż wyniosły i bezlitosny, który w wczorajszym dniu rozkazał złupić miasto, dziś zażądał od tego samego miasta także kontrybucji 300000 guruszów. Starszych polskich i ormiańskich, także duchowieństwo zgromadził w ratuszu [i] zamknął, mówiąc: «Nie wyjdziecie stąd, póki rzeczonej kontrybucji nie podzielicie na kościoły, duchowieństwo i innych obywateli, abyście do dziesiątego dnia całą sumę mi wypłacili. Zaś, gdy rzeczonego dnia nie będzie wypłacona w całości, siłą moich żołnierzy będę ją wybierał». Tutejsi nierozsądni starsi nałożyli na mnie [sumę] tysiąc guruszów, nie zważając ani na moje ubóstwo, ani na zrabowanie mojego mienia. Na drugi dzień wysłali do mnie zarządzenie o [tym] oszacowaniu, powiadamiając o powinności niezwłocznego zapłacenia. Gdy dowiedziałem się o sprawie i rozważyłem niemożność spłaty, pozbawiony wszystkiego, co miałem (choć i tak mało), i zagrożenie, które wisiało nade mną - trafić w ręce schizmatyków - postanowiłem uciec na jakiś czas”, P. Mnatsak any an, $O$ „,Diariuszu przygody w naszym kraju Lechów w roku Pańskim 1704" oraz o jego autorze, w: Ormianie polscy: kultura i dziedzictwo. Studia i materiaty źródłowe zebrane dla uczczenia jubileuszu dziesięciolecia Fundacji Kultury i Dziedzictwa Ormian Polskich, red. A. A. Zięba, Warszawa-Kraków 2016, s. 153-154. 
w sposób arbitralny. Stąd też zrozumiała jest reakcja arcybiskupa Hunaniana, który uznał przypisaną mu kwotę za absurdalną (biorąc jeszcze pod uwagę złupienie jego majątku). Kwoty wyznaczone według początkowej umowy ze Szwedami poszczególnym grupom i osobom prezentuje podsumowanie na s. 193 rękopisu:

\begin{tabular}{|l|r|}
\hline \multicolumn{1}{|c|}{ Comput taxy } & Talerów bitych \\
\hline Summy kościelne & 85880 \\
\hline Skarb królewski & 3000 \\
\hline Skarb zamkowy & 1000 \\
\hline Żydzi mieyscy y przed[mieyscy] & 120000 \\
\hline Grecy y Orm[ianie] orientalni & 30000 \\
\hline Skrzynki ich bractw & 5000 \\
\hline PP. Szoci & 4000 \\
\hline P. Szmit gospodarz pałacu królewskiego & 800 \\
\hline Mieszczanie Polacy, Orm[ianie], Rus[ini] y sławetni Kami[enicznicy?] & 42000 \\
\hline Profugowie debitores & 3930 \\
\hline Sum[ma] sum[marum] & 295610 \\
\hline Brakuie & 4390 \\
\hline Według umowy miasta z generałami szwedzkiemi & 300000 \\
\hline
\end{tabular}

Tabela 6. Sumy na okup dla Szwedów w 1704 roku

Ostatecznie wydaje się, że badając rejestr z 7 września 1704 roku, można uzyskać obraz mniej dokładny od wynikającego z rejestru z 1653 roku i wyrażającego w większym przybliżeniu stosunki majątkowe w mieście i wśród samych Ormian. Więcej danych mogłaby przynieść koekwacja po 1704 roku, jeśli takowa została przeprowadzona, co jest raczej wątpliwe ze względu na skalę zniszczeń i rabunków po pobycie Szwedów, jak również fakt, że nie był to ostatni okup zapłacony przez Lwów w trakcie III wojny północnej ${ }^{43}$.

INTERPRETACJA REJESTRU „SAMI ORMIANIE” (s. 202-203) I PORÓWNANIE GO Z INFORMACJAMI O ORMIANACH Z REJESTRU OGÓLNOMIEJSKIEGO

Wspomniane wyżej krótkie rejestry (a właściwie bilanse) z 1704 roku, znajdujące się na s. 199 i 200-201, zawierają dane o dalszym przebiegu procesu ściągania kontrybucji. Jednak wydaje się, że w stosunku do Ormian nie wnoszą wiele nowego. Ciekawą informacją w nich zawartą jest natomiast wiadomość, że Żydzi ostatecznie dali jedynie 32000 talarów w stosunku do 120000 początkowo im naznaczonych (s. 199, 200). Inną ciekawostką jest pojawienie się na liście osób, którym wypłacono jako zdobywcom „honoraria”, Stanisława Leszczyńskiego (s. 201), co przeczyłoby tezie, że Szwedzi nałożyli okup na miasto, „nie zważając na błagania stronników Leszczyńskiego"44.

\footnotetext{
${ }^{43}$ L. Podhorodecki, Dzieje Lwowa, s. 93.

${ }^{44}$ Ibidem.
} 
Dla niniejszego studium większe znaczenie ma jednak rejestr znajdujący się na s. 202-203 rękopisu. Może on stanowić cenne uzupełnienie informacji o Ormianach znajdujących się w rejestrze ogólnomiejskim (s. 185-194) i przyczynić się do zwiększenia rzetelności ujednoliconej tabeli, na której przeprowadzone zostaną badania. Tytuł tego dokumentu brzmi: „Regestr co sami P.P. Ormianie y wdowy wydali na contrybutią szwedzko podczas wzięcia miasta Lwowa". Dokument opatrzony jest datą „wrzesień 1704 roku”.

Tytuł rejestru sugeruje, że mamy do czynienia z kwotami rzeczywiście zapłaconymi przez Ormian. Niezbędnym zabiegiem jest więc porównanie osób i kwot im przypisanych z kwotami przypisanymi Ormianom-mieszczanom w rejestrze ogólnomiejskim, bo niewątpliwie to o nich chodzi, a nie o Ormian „orientalnych". Na szczęście Ormian na liście mieszczan lwowskich jest łatwo odróżnić od pozostałych dzięki dopiskom „orm.”, „or.” bądź „ormie.”, jak również dzięki charakterystycznym imionom (co jednak nie sprawdziło się we wszystkich przypadkach). Spośród 251 pozycji na liście mieszczan na s. 186-191 tak zidentyfikowani Ormianie-mieszczanie stanowią niecałą $1 / 3$ (80 pozycji). Nie ma niestety gwarancji, że dopisek „orm” znalazł się przy nazwiskach wszystkich Ormian na tej liście, ale można, właśnie za sprawą rejestru „samych Ormian” na s. 202-203, przypuszczać, że otrzymała go znaczna większość Ormian.

Porównując listy Ormian z rejestru ogólnomiejskiego i „samych Ormian”, zauważamy, że znaczna większość osób powtarza się w obu rejestrach, jednak są też osoby niewystępujące $\mathrm{w}$ jednym bądź drugim spisie. Oznacza to, że rejestr na s. 202-203 nie jest tylko prostym wyciągiem pozycji dotyczących Ormian z rejestru ogólnomiejskiego. W rejestrze „samych Ormian” jest łącznie 79 osób (1 pozycja mniej niż w rejestrze ogólnomiejskim), natomiast zawiera on 10 nazwisk niewystępujących w rejestrze ogólnomiejskim, co z kolei oznacza, że rejestr ogólnomiejski zawiera 11 nazwisk niewystępujących w rejestrze „samych Ormian". Listy te dotyczą więc dwóch zbiorów osób z zasadniczą częścią wspólną, jednak nie tożsamych. Kolejnym argumentem przemawiającym za tym, że lista „samych Ormian” to osobny rejestr, a nie wyciąg z rejestru ogólnomiejskiego, jest fakt, że kolejność występowania nazwisk Ormian w obu rejestrach nie jest w pełni zgodna.

Kwoty przypisane osobom pojawiającym się w obydwu rejestrach są w przeważającej części zbieżne. W kilku wypadkach kwoty przy nazwiskach ujęto w nawiasy kwadratowe i nie wliczono ich do końcowego podsumowania, co może oznaczać, że te nie zostały wpłacone przez zobowiązane do tego osoby. Natomiast całkowita kwota przypisana Ormianom w obu rejestrach wyniosła, pomimo że na listach były różne osoby, prawie tyle samo: 22392 talarów w rejestrze ogólnomiejskim w stosunku do 22382 talarów w rejestrze „samych Ormian”"45.

${ }^{45} \mathrm{Na}$ końcu rejestru „samych Ormian” do kwoty 22382 doliczono jeszcze około 5000 talarów zapłacone osobno przez Kościół ormiański (s. 203). Znajduje się tam również dopi- 
Szwedów prawdopodobnie nie obchodziło, kto ostatecznie złoży się na przypisaną poszczególnym grupom osób kwotę, byleby suma końcowa się zgadzała.

$\mathrm{Na}$ podstawie powyższych danych można przyjąć, że rejestr „samych Ormian" na s. 202-203 rzeczywiście, zgodnie z tytułem dokumentu, zawiera kwoty ostatecznie zapłacone przez Ormian-mieszczan szwedzkiemu okupantowi, w większości zgodnie z tym, co zostało im naznaczone w taksie ogólnomiejskiej. Ten wniosek będzie pomocny przy konstruowaniu ujednoliconej tabeli do dalszych badań.

Metodologia opRacowania UJEDNOLICONEJ TABELI NA PODSTAWIE REJESTRÓW Z 1704 ROKU $^{46}$

Przy konstruowaniu tabeli należało przede wszystkim, z racji tego, że w artykule badaniu podlega gmina ormiańska we Lwowie, wyodrębnić z rejestru ogólnomiejskiego samych Ormian-mieszczan. Przyjęto przy tym, że grupa określona w rejestrze jako „Ormianie orientalni” oznacza Ormian bez praw miejskich, czyli znajdujących się poza badaną gminą. Prawdopodobnie ci z Ormian, którzy nie zostali wymienieni na liście razem z mieszczanami, zamieszkiwali w większości przedmieścia, $\mathrm{w}$ tym podmiejskie jurydyki ${ }^{47}$.

Ormian-mieszczan wyodrębniono spośród pozostałych mieszczan w rejestrze ogólnomiejskim dzięki wspomnianym już dopiskom. Następnie połączono tę listę z listą ,samych Ormian”. Ostatecznie otrzymano trzy kolumny w tabeli: nazwisko, kwota do zapłaty (z rejestru ogólnomiejskiego) i kwota zapłacona (z rejestru „samych Ormian”). Wiersze tabeli uporządkowano, podobnie jak w przypadku rejestru z 1653 roku, według wysokości wkładu do okupu, czyli od najwyższej do najniższej kwoty w kolumnie „do zapłaty”. Usunięto podsumowania kwot z kolejnych kolumn w rękopisie, zostawiając tylko sumy końcowe pokazujące, ile łącznie dali Ormianie.

Tabela (z trzema kolumnami) znajduje się w Aneksie 2. Ukazuje ona niemal identyczne sumy kwot „,do zapłaty” oraz „zapłaconych”. Natomiast do przeprowadzenia badań użyto tabeli $\mathrm{z}$ dwiema kolumnami - jedną z nazwiskami, drugą powstałą z połączenia danych z kolumn „do zapłaty” i „,zapłaconych”. Zazwyczaj, co widać w aneksie, kwoty te były takie same, w przypadku różnicy wybierano kwotę wyższą. Te kolumny można było połączyć także dlatego, że większość występujących w nich osób się powtarzała (oprócz wspomnianych już 10 lub 11 pozycji). Otrzymano w ten sposób tabelę zawierającą 90 wierszy.

Opracowując tabelę od strony pisowni, tak jak w przypadku rejestru z 1653 roku usunięto znajdujące się przy imionach dopiski grzecznościowe, takie jak:

sek: ,a co poginęło przy tym oprócz Szwedóf Bug wi wiele”. Dopisek ten to jedno z kilku w rękopisie świadectw ogromu zniszczeń w trakcie pobytu wojsk szwedzkich we Lwowie.

46 Zob. Aneks 2.

${ }^{47}$ L. Podhorodecki, Dzieje Lwowa, s. 94. 
„P.”, „ImP.”, „Pani”. Usunięto też wspomniane wyżej dopiski „orm.”. Pozostawiono natomiast dopiski „S.O.L.”, „S.L.O.” bądź „S.O.”, które prawdopodobnie należy rozumieć jako „starszy/sędzia Ormian lwowskich”. W dwóch przypadkach dopisek S.O.L. znajdował się przy imionach kobiet, co można rozumieć dwojako: kobiety te były wdowami po starszych (sędziach) ormiańskich albo płaciły pod nieobecność mężów. O tym, że ta druga możliwość wchodziła w grę, świadczy dopisek przy nazwisku innej kobiety: „Pani Gurnowilowa bo samego nie było" (s. 202).

Niewątpliwą korzyścią wynikającą z istnienia dwóch rejestrów zawierających imiona w większości tych samych osób była możliwość sprawdzenia poprawności bądź uzupełnienia niektórych nazwisk. Przykładowo w rejestrze ogólnomiejskim występuje Stefanowicz Augustyn, podczas gdy w spisie „samych Ormian” ma on dopisek ,sukiennik". Podobnie w rejestrze ogólnomiejskim pojawia się Derwaszkiewicz, a w rejestrze ,samych Ormian” Stefan Derwaszkiewicz. W każdym takim wypadku zawsze wybierano pełniejszą wersję nazwy identyfikującej daną osobę, zwracając przy tym uwagę, czy to na pewno ta sama osoba. Pomocna w identyfikacji była kolejność w spisie, jak również zgodność kwot przypisanych do danej osoby w obu rejestrach.

\section{ANALIZA REJESTRÓW Z 1704 ROKU POD KĄTEM LICZEBNOŚCI I STRUKTURY MAJĄTKOWEJ GMINY ORMIAŃSKIEJ \\ Dzięki stworzonej według wyżej przedstawionych pryncypiów tabeli możliwe było powtórzenie przynajmniej części badań z zakresu demografii historycznej, które udało się przeprowadzić na rejestrze koekwacji z 1653 roku.}

\section{Liczebność gminy ormiańskiej w 1704 roku}

Podobnie jak rejestr z 1653 roku rejestry z 1704 roku nie mogą dać odpowiedzi na pytanie o dokładną liczbę Ormian należących do gminy we Lwowie. Podobnie też należy stwierdzić, że zawierają one nazwiska większości Ormian należących do gminy, ale nie wszystkich. Z pewnością rejestry z 1704 roku nie dotyczyły Ormian mieszkających pod miastem, bo ci zostali nazwani w rejestrze ogólnomiejskim Ormianami „orientalnymi”.

Na pierwszy rzut oka wydaje się, że gmina w 1704 roku była mniej liczna niż w 1653 roku; prawdopodobnie tak też było. Rejestr z 1653 roku zawiera 147 pozycji w stosunku do 90 pozycji w tabeli powstałej z połączenia spisu Ormian-mieszczan i ,samych Ormian”. Jest to więc spadek o około 40\% w ciągu 50 lat. Przełożenie tych wartości na rzeczywistą liczebność gminy może się jednak odbyć tylko na drodze oszacowania.

Warto w tym miejscu wrócić do omawianej już uwagi kopisty znajdującej się na końcu rejestru z 1653 roku (s. 165), w której porównuje on liczebność gminy ormiańskiej w 1653 i 1704 roku, wyrażając przy tym swoją opinię na temat stanu gminy w jego czasach (1713 roku). Kopista wymienia liczby 147 „dających” (na 
okup) z 1653 roku i 73 „dających” z 1704 roku. Liczby te, jak już zaznaczono, oznaczają tylko pozycje w rejestrach, przy czym druga liczba jest podana błędnie i powinna wynosić 79 (kopista miał na myśli „samych Ormian” na s. 202-203). Następnie kopista wylicza kolejne jeszcze kontrybucje płacone do 1713 roku oraz dodaje: „wniwecz się obróciła cała Natia, że teraz in A. 1713 kiedy by na to przyszło [na płacenie kontrybucji] czego uchoway Boże, ledwo by na tysiąc talerów podobnym cotrybutiom wystarczyli bo y person mniey y ubóstwa wcale pełno”. Ta uwaga świadczy dobitnie o upadku gminy - zarówno liczebnym, jak i majątkowym.

Biorąc pod uwagę ogólny spadek liczby mieszkańców Lwowa w drugiej połowie XVII i na początku XVIII wieku, można zakładać, że gmina ormiańska lwowska nadal stanowiła kilka procent ogólnej liczby mieszkańców. Przyjmując podobne, bardzo przybliżone szacunki jak w przypadku rejestru z 1653 roku, można oszacować ogólną liczbę Ormian wewnątrz murów w 1704 roku na około 250 osób (50 lat wcześniej - około 400 osób). W ogólnomiejskim rejestrze osób mających płacić na okup dla Szwedów pozycji dotyczących mieszczan nie-Ormian było jedynie 171 (dotyczących Ormian - 80), co również można uznać za przejaw upadku mieszczaństwa i miasta w ogóle.

STRUKTURA SPOŁECZNO-MAJĄTKOWA GMINY W 1704 ROKU W PORÓWNANIU Z ROKIEM 1653

Po zbadaniu liczebności gminy ormiańskiej na podstawie rejestrów z 1704 roku można pokusić się o przeprowadzenie badań nad strukturą społeczno-majątkową gminy. Niestety, jak już zaznaczono, w przypadku rejestrów z 1704 roku nie dysponujemy oszacowaniami majątków w mieście, a jedynie sumami wyznaczonymi do zapłaty poszczególnym osobom bądź grupom osób. W przypadku Ormian mamy też, jak udało się już ustalić, listę kwot rzeczywiście zapłaconych na okup. Podstawą do badań będzie opisana wyżej ujednolicona tabela powstała z połączenia danych o Ormianach zawartych w rejestrze ogólnomiejskim i rejestrze „samych Ormian”.

By móc zestawić całkowite kwoty okupów z lat 1648 i 1704, należy rozważyć kwestię zmian w kursie talara bitego i złotego. Jest to problem wysoce złożony, jednak można z pewnością stwierdzić, że kurs złotego w stosunku do talara spadł w ciągu tego półwiecza; dowody znajdują się w badanym rękopisie. Na s. 165 w przytaczanym już podsumowaniu rejestru koekwacji z 1653 roku widnieje informacja, że 91421 złotych 10 groszy „uczyni na talery bite” 30 473,23, co oznacza, że w tamtym okresie jeden talar odpowiadał trzem złotym. Z kolei na s. 199 rękopisu, w jednym z bilansów kontrybucji dla Szwedów znajdujemy informację, że „talery 338 546,8 facit florenów 2708 368”, co oznaczałoby, że w 1704 roku jeden talar odpowiadał już ośmiu złotym. Podobna informacja pojawia się w przytaczanym już diariuszu z 1704 roku, gdzie jest mowa o „14 polskich złotych, co było mniej niż dwa gurusze [czyli 
talary]"48. Na podstawie tej informacji znowu można przyjąć, że jeden talar to około ośmiu złotych. $Z$ powyższych informacji jasno wynika, że kurs złotego w stosunku do talara na przestrzeni 50 lat spadł ponad dwuipółkrotnie.

Przyjmując więc za bazę do porównania talary bite, należy przeliczyć kwoty z 1653 roku po starym kursie, to jest jeden do trzech. Przy takim przeliczniku łączną kwotę okupu z 1648 roku (około 500000 złotych) można wyrazić jako 166 6662/3 talarów. Ormianie, według wyżej przeprowadzonych ustaleń, mieliby zapłacić po wyrównaniu około 17-18\% tej sumy, czyli wymienione już 30 473,23 talara. W przypadku zaś kontrybucji z 1704 roku Ormianie-mieszczanie mieli zapłacić, i najprawdopodobniej zapłacili, około 22392 talary, czyli niecałe 7,5\% wyznaczonej przez Szwedów sumy 300000 talarów. Czy była to kwota o wyższej bądź niższej wartości realnej niż ta z 1653 roku - trudno rozstrzygać, natomiast spadek udziału procentowego wkładu Ormian należących do gminy do całości okupu o około 10 punktów procentowych może dodać jakiś rys do ogólnego wyobrażenia o stanie lwowskiej gminy ormiańskiej w tym okresie. Trzeba przy tym zaznaczyć, że Ormianie-mieszczanie dali w 1704 roku 53\% kwoty 42000 talarów zapłaconych przez całe mieszczaństwo, przy liczbowym udziale $\mathrm{w}$ grupie mieszczan $\mathrm{w}$ wysokości około $1 / 3$. W celu uzyskania danych na temat procentowego udziału wkładu Ormian do kwoty zapłaconej przez mieszczaństwo w 1648 roku należałoby przyjrzeć się rejestrom wyrównania ogólnomiejskiego z 1656 roku.

Najbogatszym Ormianinem-mieszczaninem płacącym na okup dla Szwedów w 1704 roku był niewątpliwie Dominik Bogdanowicz ${ }^{49}$, starszy (sędzia) ormiański, który wyłożył kwotę 7000 talarów bitych. Sadok Barącz opisuje go jako „najbogatszego kupca we Lwowie”, co od razu każe nam porównać postać Bogdanowicza z Janem Warteresowiczem z rejestru z 1653 roku, w tamtym okresie również uznanym za najbogatszego mieszczanina lwowskiego. Pamiętamy, że Jan Warteresowicz dał na okup dla Chmielnickiego 32000 złotych, co zgodnie z ówczesnym kursem wynosiło 10 6662/3 talarów. Oczywiście kwoty te nie są możliwe do bezpośredniego zestawienia ze względu na różnice w cenach, jednak widać, że rząd wielkości był mniej więcej ten sam (mimo że nominalnie Bogdanowicz wyłożył tylko $2 / 3$ tego, co Warteresowicz), a więc nie sposób odmówić bogactwa Bogdanowiczowi. Sprawdźmy, jak przedstawiała się kwota przypisana Bogdanowiczowi, która musiała wynikać z wyobrażenia o jego bogactwie, w stosunku do kwot przypisanych pozostałym Ormianom.

Najbiedniejszy z Ormian płacących na okup w 1704 roku, Zachariasz Głuszkiewicz (z wymownym dopiskiem ,ubogi”), dał jedynie 2 talary. Jak łatwo policzyć, Dominik Bogdanowicz wyłożył kwotę 3500 razy wyższą niż on. Jak ta

48 P. Mnatsakanyan, O „Diariuszu przygody...”, s. 154.

49 S. Barącz, Żywoty sławnych Ormian, s. 81-82; Dominik Bohdanowicz, [online] http:// www.wiki.ormianie.pl/index.php?title=Dominik_Bohdanowicz, 2 VII 2017. 
różnica, jeszcze większa niż pomiędzy najbogatszym i najbiedniejszym Ormianinem w 1653 roku (wtedy była to 2000-krotność), przekłada się na wskaźniki statystyczne?

Średnia arytmetyczna z kwot w tabeli powstałej z połączenia rejestru Ormian-mieszczan (kwoty do zapłaty) i ,samych Ormian” (kwoty zapłacone) wynosi około 274 talary. Po odrzuceniu wartości najwyższej najbardziej odbiegającej od reszty (7000 talarów Dominika Bogdanowicza) średnia wynosi już tylko około 199 talarów. Z kolei mediana w tej kolumnie to 100 talarów.

Podział na grupy majątkowe do wykresu rozwarstwienia majątkowego wynikał z rozkładu sum do zapłaty lub zapłaconych. W tabeli do wykresu wyodrębniono, podobnie jak w przypadku rejestru z 1653 roku, cztery grupy majątkowe. Jednak tutaj właściwszy był podział na przedziały zamknięte od góry pełnymi setkami talarów (2-100, 101-200, 201-500) niż dołączanie pełnych setek do wyższych przedziałów (2-99, 100-199, 200-499). Powodem ich użycia była duża częstotliwość występowania kwot wyrażonych pełnymi setkami talarów: aż 18 osób miało przypisaną kwotę 100 talarów, $14-200$ talarów.

Teoretycznie w celu porównania danych z tabel dla lat 1653 i 1704 należałoby dokonać klasyfikacji kwot według przedziałów wyrażonych procentowo w stosunku do całości sumy rozumianej dla 1653 roku jako suma oszacowań majątków, a dla 1704 roku jako suma kwot przypisanych poszczególnym osobom. Dla 1653 roku grupy podzielono według wzorca: pierwsza - do 0,3\% całości, druga - do $0,6 \%$ całości, trzecia - do $1,2 \%$ całości, czwarta - powyżej 1,2\% całości. Jednak gdyby identyczny podział zastosować dla danych z 1704 roku, moim zdaniem zaciemniłoby to tylko obraz sytuacji, właśnie z uwagi na wspomniane duże grupy osób płacące dokładnie po 100 i 200 talarów, które niekoniecznie znalazłyby się w odpowiednich grupach majątkowych. Dlatego ostatecznie zdecydowano się na zastosowanie podziału na grupy 2-100, 101-200, 201-500 i powyżej 500 talarów, co odpowiada podziałowi na grupy: pierwsza - do $0,4 \%$ całości, druga - do $0,8 \%$ całości, trzecia - do $2 \%$ całości, czwarta - powyżej 2\% całości.

Oczywiście, jak to już zostało zaznaczone, kwoty do zapłaty bądź zapłacone zawarte $\mathrm{w}$ rejestrach z 1704 roku niekoniecznie wynikają z oszacowania majątków tak jak w 1653 roku, jednak na pewno mogą stanowić podstawę do wnioskowania o rozwarstwieniu majątkowym w gminie ormiańskiej.

Zauważalne jest uderzające podobieństwo tego schematu do wykresu 1. Tak samo jak w 1653 roku w 1704 roku około $2 / 3$ Ormian znalazło się w grupie najuboższej, a najbogatsi stanowili około osób w gminie. Siedem osób należących do najbogatszej grupy w 1704 roku miało zapłacić 60\% kwoty przypisanej wszystkim Ormianom; w 1653 roku majątek 11 osób należących do najbogatszej grupy został oszacowany na $2 / 3$ całości. Dla lepszego przedstawienia danych zestawiono ze sobą dwa wykresy pokazujące rozwarstwienie majątkowe. 


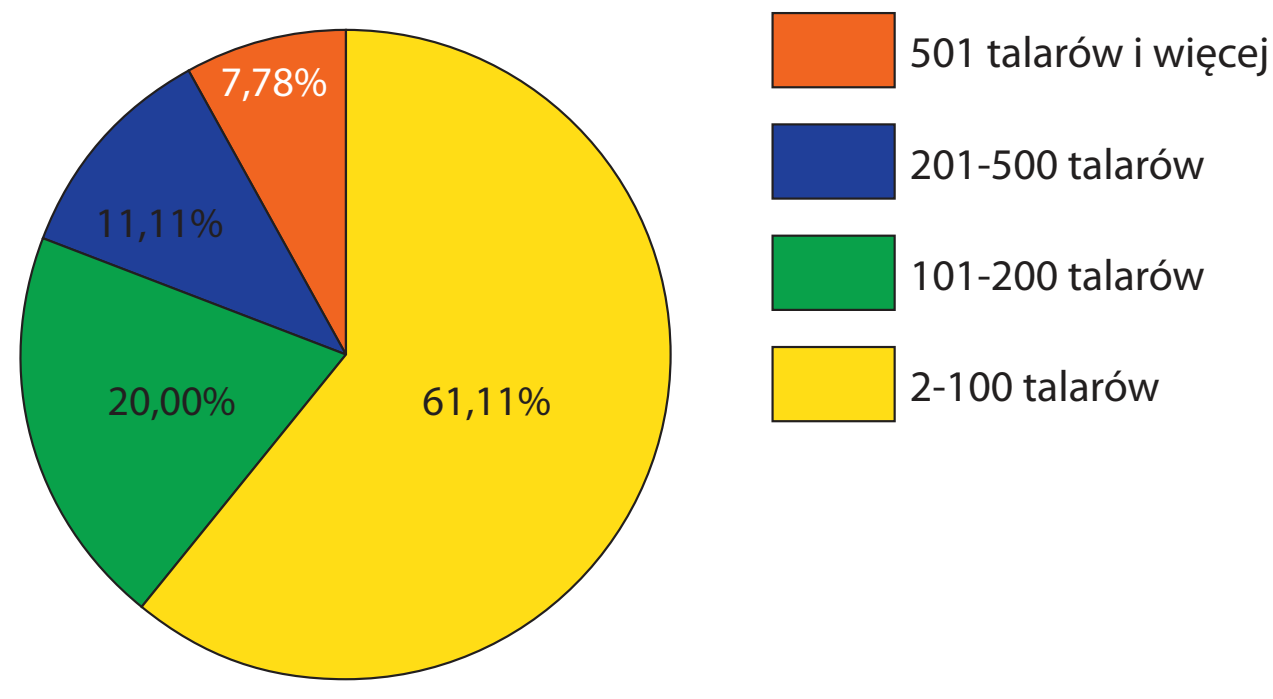

Wykres 4. Rozwarstwienie majątkowe w gminie ormiańskiej we Lwowie w 1704 roku

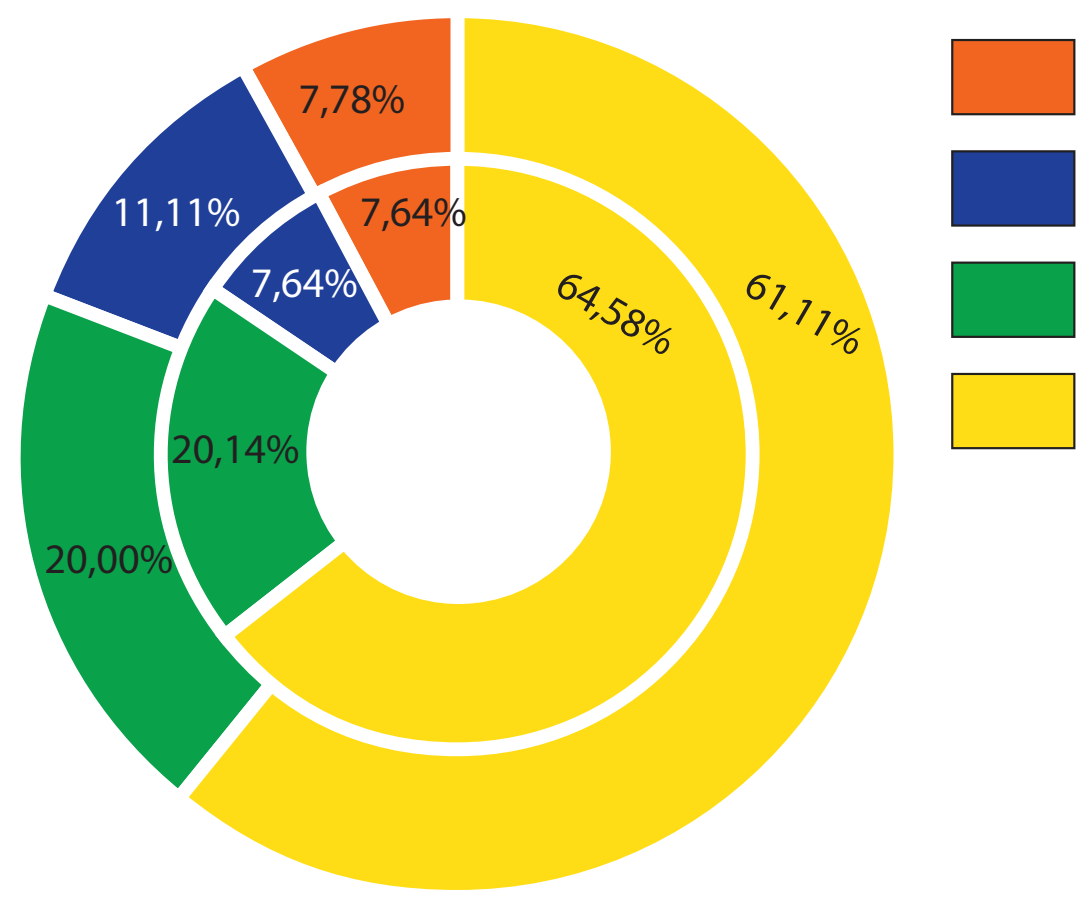

grupa najbogatsza

grupa średniozamożna 2

grupa średniozamożna

grupa najuboższa

Wykres 5. Rozwarstwienie majątkowe w gminie ormiańskiej we Lwowie w latach 1653 i 1704

Można by powiedzieć, że to odpowiedni dobór przedziałów majątkowych sprawił, iż wykresy są tak podobne. Jednak powinniśmy także zwrócić uwagę na podobieństwo indeksu Giniego dla obu tabel. W 1653 roku wynosił on około 0,78 dla wszystkich pozycji w tabeli i około 0,63 przy pominięciu dwóch najwyższych pozycji. Dla 1704 roku indeks ten wynosił odpowiednio około 0,73 dla wszystkich pozycji i około 0,65, jeśli pominąć najbogatszego Dominika Bogdanowicza. Widzimy więc, że rozwarstwienie majątkowe w gminie w ciągu tych 50 lat nie 
zmieniło się w sposób istotny i większość majątku nadal pozostawała w rękach nielicznej grupy najbogatszych.

W tym miejscu warto zwrócić uwagę na wyniki badań przeprowadzonych przez Katarzynę Wagner na potrzeby jej doktoratu dotyczącego między innymi nierówności majątkowych we Lwowie ${ }^{50}$. Na podstawie analizy rejestrów poborów szosu miejskiego oraz kontrybucji dla Szwedów autorka obliczyła współczynnik Giniego dla Lwowa za lata 1636, 1665 oraz 1702. Wyniósł on odpowiednio $0,286,0,418$ i 0,604 . Widać więc wyraźną tendencję wzrostową, czego nie można zaobserwować w przypadku gminy ormiańskiej w drugiej połowie XVII i początkach XVIII wieku. Dla tejże gminy współczynnik Giniego był wyjątkowo wysoki zarówno w 1653, jak i w 1704 roku, choć w tym drugim wypadku był zdecydowanie bliższy wynikom obliczeń zawartych w cytowanej pracy doktorskiej.

Ciekawe jest również zestawienie wyników obliczeń zawartych w tej pracy obrazujących wkład najbogatszej grupy osób w ogólną sumę podatku płaconego przez miasto z podobnymi wyliczeniami dla Ormian składających się na okupy. W 1665 roku 10\% najzamożniejszych osób we Lwowie uiszczało 31\% podatku, podczas gdy w 1653 roku $10 \%$ najbogatszych Ormian składających się na okup zapłaciło około $71 \%$ całej kwoty naznaczonej gminie. Z kolei w 1702 roku $10 \%$ najbogatszych mieszczan uiściło prawie $47 \%$ podatku, a $10 \%$ Ormian z najwyższej grupy majątkowej, płacąc na kontrybucję dla Szwedów w 1704 roku, złożyło się na 64\% całej kwoty zapłaconej przez Ormian. Dostrzegalna jest więc tendencja spadkowa w przypadku Ormian, przeciwna do tendencji ogólnomiejskiej. Widać również znacznie wyższy wkład najbogatszych Ormian w wysiłek finansowy podejmowany przez całą gminę niż w przypadku danych dla całego miasta. Kolejne tego typu zestawienia z pewnością mogą się przyczynić do rozwoju wiedzy na temat gminy ormiańskiej we Lwowie i jej rzeczywistego miejsca w miejskim organizmie.

\section{MAJĄTEK POSZCZEGÓLNYCH GRUP W GMINIE W 1704 ROKU}

W przypadku rejestrów z 1704 roku trudniejsze niż dla dokumentu z 1653 roku jest wyróżnienie poszczególnych grup ludności w gminie ormiańskiej. W rękopisie nie ma obszernego materiału źródłowego pozwalającego na jednoznaczną identyfikację osób. Takim materiałem dla rejestru z 1653 roku była pierwsza część rękopisu. Część starszych ormiańskich, zwanych już w 1704 roku sędziami, można jednak znaleźć w dwóch aktach elekcji sędziów ormiańskich (z lat 1712 i 1713), znajdujących się na s. 141 i 143 rękopisu. W wyodrębnieniu z rejestrów tej grupy mogą też pomóc wspomniane już dopiski przy niektórych nazwiskach (S.O.L., S.L.O. lub S.O.), oznaczające prawdopodobnie starszych/sędziów Ormian lwowskich. Jeśli pominąć dwie kobiety na liście z tym dopiskiem,

${ }^{50}$ K. Wagner, „Mieszczanie i podatki. Nierówności majątkowe w wybranych miastach Rzeczypospolitej XVII w.” [praca doktorska], Warszawa 2016, s. 80-82. 
o których również wspominano, zostaje 13 nazwisk, z czego 8 pojawia się w aktach elekcji z lat 1712 i 1713. Trudno w tym miejscu stwierdzić, dlaczego jest to 13, a nie 12 nazwisk; tylu przecież moglibyśmy się spodziewać po tradycyjnej liczbie starszych ormiańskich zasiadających w radzie. Być może dopisek S.O.L. pojawił się przy którejś z osób błędnie bądź dwie osoby zdążyły się zmienić na stanowisku pomiędzy powstaniem kolejnych rejestrów z 1704 roku.

\begin{tabular}{|c|c|c|c|}
\hline Nazwisko & $\begin{array}{l}\text { Kwota przy- } \\
\text { pisana (tal.) }\end{array}$ & Elekcja 1712 & Elekcja 1713 \\
\hline Dominik Bogdanowicz S.O.L. y D[irector] & 7000 & & \\
\hline Łazarz Steckiewicz S.O.L. & 3000 & $x$ & $x$ \\
\hline Mikołay Manczukiewicz stary S.O.L. & 300 & $x$ & $x$ \\
\hline [Jakub] Minassewicz stary S.L.O. & 300 & & \\
\hline Mikołay Hadziesowicz S.O.L. & 300 & & \\
\hline Stefan Derwaszkiewicz S.O.L. & 250 & $x$ & $x$ \\
\hline Pirumowicz Jakub S.O.L. & 200 & & \\
\hline Krzysztof Steckiewicz S.O.L. & 200 & & \\
\hline Krzysztof Augustynowicz S.O.L. & 200 & $x$ & $x$ \\
\hline Grzegorz Bernatowicz S.O. & 100 & $x$ & $x$ \\
\hline Zachariasz Bernatowicz S.O.L. & 100 & $x$ & $x$ \\
\hline Jan Steckiewicz S.O.L. & 10 & $x$ & zmarł \\
\hline Mikołay Zahnowicz S.O.L. & 10 & $x$ & $x$ \\
\hline
\end{tabular}

$\mathrm{x}$ - wystąpienie nazwiska w akcie elekcji

Tabela 7. Starsi (sędziowie) ormiańscy w rejestrach z lat 1704, 1712 i 1713

Podobnie jak w tabeli dla 1653 roku tutaj także znajdują się dowody na to, że starsi ormiańscy nie byli wyłącznie reprezentacją grupy najbogatszych kupców ormiańskich, a rozstrzał majątkowy pomiędzy najbogatszym i najbiedniejszym z nich był ogromny. W 1653 roku majątek najbiedniejszego starszego wyceniono na $0,5 \%$ majątku najbogatszego, a w 1704 roku najbiedniejszy starszy miał przypisaną kwotę do zapłaty stanowiącą $0,14 \%$ kwoty przypisanej najbogatszemu. W 1704 roku w grupie najbogatszych osób w gminie znalazło się jedynie dwóch starszych ormiańskich (w 1653 roku było ich czterech).

STOSUNEK SUMY MAJĄTKÓW POSZCZEGÓLNYCH GRUP DO ICH LICZEBNOŚCI W 1704 ROKU

W rejestrach z 1704 roku pojawiają się następujące grupy osób: sędziowie/starsi, pozostali mężczyźni (pospólstwo), kobiety (część z nich to na pewno wdowy) i grupy osób. W stosunku do rejestru z 1653 roku jest tu o 54 pozycje mniej. Występują tylko trzy grupy osób pod jedną pozycją (w 1653 roku było 10 pozycji sierot), stąd nie wyróżniono ich jako osobnej grupy, lecz włączono bądź do pospólstwa, bądź do kobiet. 


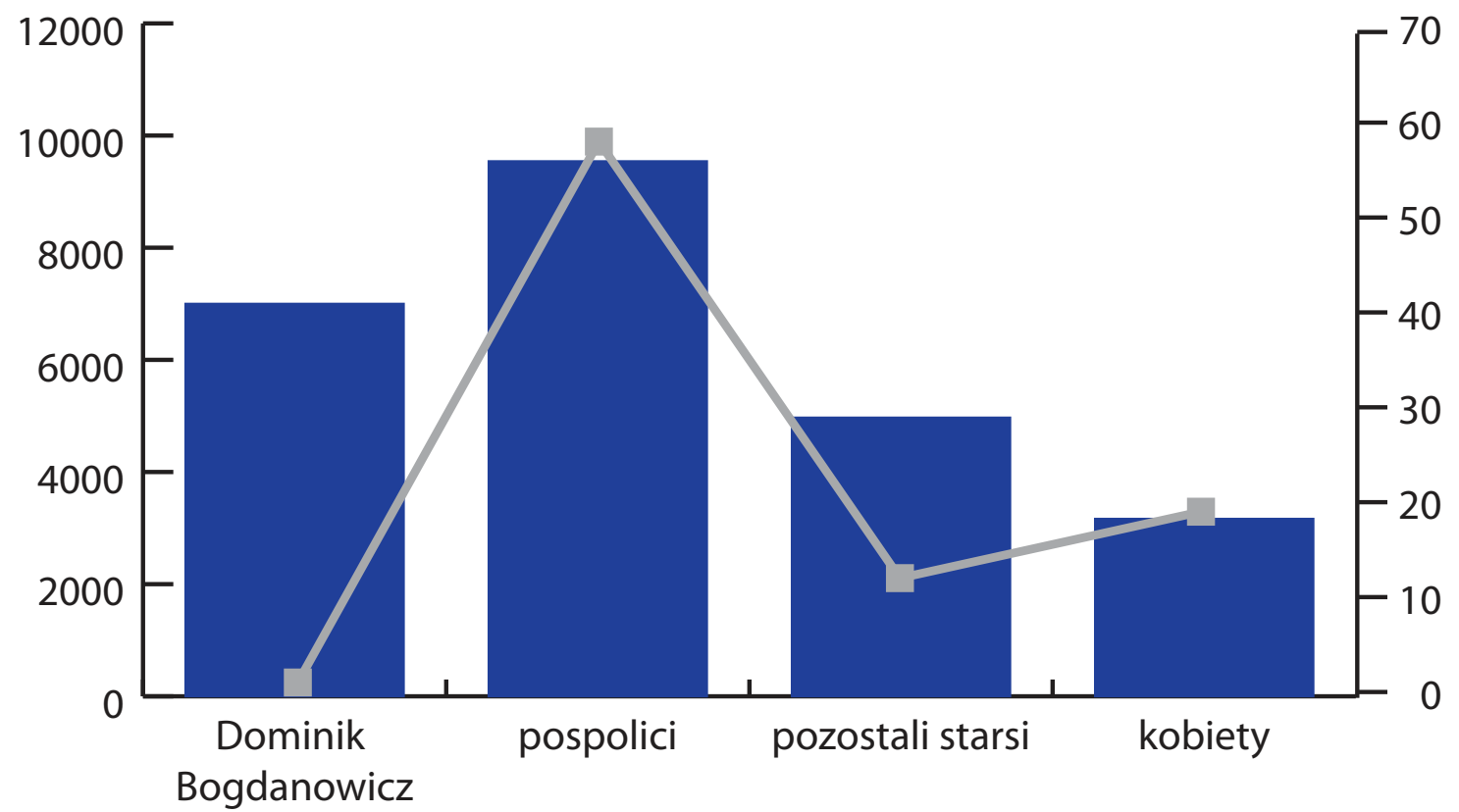

oszacowanie majątku (zł)

liczebność

Wykres 6. Wysokość składki na okup a liczba osób w gminie w 1704 roku

Podobnie jak wykres dla 1653 roku również ten powyższy prezentuje sytuację, w której w gminie jest jeden bardzo bogaty człowiek, a daleko za nim i kilkoma innymi zamożnymi osobami tłoczy się na drabinie majątkowej reszta starszych, pospólstwa i kobiet. Można policzyć średnią dla wyróżnionych grup osób: starsi bez Dominika Bogdanowicza wypadają najlepiej, ze średnią około 414 talarów, choć trzeba pamiętać o dużym rozwarstwieniu w obrębie tej grupy. Pospolici i kobiety mają podobną średnią, około 165 talarów, dlatego żadnej z tych dwóch grup nie można ocenić jednoznacznie jako najuboższej.

PODSUMOWANIE BADANIA REJESTRÓW Z 1704 ROKU W ODNIESIENIU DO WNIOSKÓW Z BADAŃ REJESTRU Z 1653 ROKU

Z badań przeprowadzonych na rejestrach z 1704 roku wynika, że liczebność gminy ormiańskiej spadła od 1653 roku. Wydaje się też, że Ormianie należący do gminy zapłacili procentowo mniejszą część całkowitej sumy okupu niż w 1648 roku, co może świadczyć o zubożeniu gminy, tak jak to opisał kopista na s. 165 rękopisu. Pomimo spadku liczebności i postępującego zubożenia wydaje się, że rozwarstwienie majątkowe wewnątrz gminy nie zmieniło się. Struktura gminy wciąż charakteryzowała się jedną bogatą osobą stojącą na czele i wysokim czynnikiem nierównomierności rozkładu majątku (indeks Giniego).

W obrębie poszczególnych grup osób również występowały duże nierówności. Najbogatszy ze starszych/sędziów ormiańskich Dominik Bogdanowicz miał dać na okup 7000 talarów, podczas gdy najbiedniejszy Mikołaj Zachnowicz - 
jedynie 10 talarów. Z pospólstwa najwięcej miał dać Piotr Gabrielowicz (1000 talarów), a Zachariasz Głuszkiewicz - tylko 2 talary. Spośród kobiet Szymunowicowa miała dać 1000 talarów, a najmniej wyznaczono do zapłacenia Stefanowej Augustynowiczowej - 5 talarów.

Warto jeszcze dodać, że w odniesieniu do dokumentów z 1704 roku potwierdziła się obserwacja zanotowana przy badaniu rejestru z 1653 roku: starsi/sędziowie ormiańscy jako grupa nie należeli wyłącznie do najbogatszych osób w gminie. Wśród nich znajdowali się zarówno bardzo bogaci, jak i przeciętni oraz biedni.

\section{Bibliografia}

\section{Źródla}

Biblioteka Zakładu Narodowego im. Ossolińskich we Wrocławiu, sygn. 1646/II „Dzieje Ormian lwowskich od r. 1649 - aż do r. 1713"

\section{Literatura}

Balzer O., Sadownictwo ormiańskie w średniowiecznym Lwowie, Lwów 1909

Balzer O., Statut ormiański w zatwierdzeniu Zygmunta I z r. 1519, Lwów 1910

Barącz S., Rys dziejów ormiańskich, Tarnopol 1869

Barącz S., Żywoty stawnych Ormian w Polsce, Lwów 1856

Bedrossian M., New Dictionary: Armenian-English, Venice 1875-1879

Charewiczowa Ł., Lwów na przełomie XVII i XVIII wieku, w: Studja z historii społecznej i gospodarczej poświęcone prof. dr Franciszkowi Bujakowi, Lwów 1931, s. 347-374

Charewiczowa Ł., Ograniczenia gospodarcze nacyj schizmatyckich $i$ żydów we Lwowie XV i XVI wieku, Lwów 1925

Czołowski A., Historja Lwowa od roku 1600 - do roku 1772, Lwów 1927

Józefowicz J. T., Lwów utrapiony in anno 1704 albo Dyjaryjusz wziętego Lwowa przez króla szwedzkiego Karola XII die 6 mensis Septembris anno 1704, Kraków 2003

Kapral M., Armenian and Ruthenian elders in Lviv in the late medieval and early modern period: their emergence, functions and interaction, w: Armenian-Ukrainian historical contacts, Lviv 2011, s. 29-40

Kopczyński M., Podstawy statystyki. Podręcznik dla humanistów, Warszawa 2005

Linde S., Stownik języka polskiego, t. 1, cz. 2, Warszawa 1808

Łoziński W., Patrycyat i mieszczaństwo lwowskie w XVI i XVII wieku, Lwów 1892

Malinowski A., Podstawy statystyki z elementami demografii, Warszawa 2009

Mnatsakanyan P., O „Diariuszu przygody w naszym kraju Lechów w roku Pańskim 1704” oraz o jego autorze, w: Ormianie polscy: kultura i dziedzictwo. Studia i materiaty źródtowe zebrane dla uczczenia jubileuszu dziesięciolecia Fundacji Kultury i Dziedzictwa Ormian Polskich, red. A. A. Zięba, Warszawa-Kraków 2016, s. 143-164

Petrowicz G., La chiesa armena in Polonia, 1: 1350-1624, Roma 1971

Petrowicz G., La chiesa armena in Polonia e nei paesi limitrofi, 3: 1686-1954, Roma 1988

Petrowicz G., L'unione degli armeni di Polonia con la Santa Sede: (1626-1686), Roma 1950 
Podhorodecki L., Dzieje Lwowa, Warszawa 1993

Rzemieniecki K., Rękopisy związane z historia i kultura Ormian w zbiorach Działu Rękopisów Biblioteki Zakładu Narodowego im. Ossolińskich, „Lehahayer” 2013, nr 2, s. $199-217$

Stopka K., Języki oswajane pismem. Alografia kipczacko-ormiańska i polsko-ormiańska w kulturze dawnej Polski, Kraków 2013

Stopka K., Ormianie w Polsce dawnej i dzisiejszej, Kraków 2000

Stopka K., Śladami kopisty Awedyka: portret rodziny Derszymonowiców, czyli mikro-historia przemian kulturowych Ormian polskich XVII wieku, „Lehahayer” 2013, nr 2, s. $81-121$

Tryjarski E., Zapisy sadu duchownego Ormian miasta Lwowa za lata 1625-1630 w języku ormiańsko-kipczackim, Kraków 2010

Wagner K., „Mieszczanie i podatki. Nierówności majątkowe w wybranych miastach Rzeczypospolitej XVII w." [praca doktorska], Warszawa 2016

Zakrzewska-Dubasowa M., Ormianie w dawnej Polsce, Lublin 1982

Zakrzewska-Dubasowa M., Ormianie zamojscy i ich rola $w$ wymianie handlowej $i$ kulturalnej między Polska a Wschodem, Lublin 1965

Zięba A. A., Daniel Zarugowicz: tragiczna kariera kamienieckiego Ormianina, w: Ormianie polscy: kultura i dziedzictwo. Studia i materiały źródłowe zebrane dla uczczenia jubileuszu dziesięciolecia Fundacji Kultury i Dziedzictwa Ormian Polskich, red. A. A. Zięba, Warszawa-Kraków 2016, s. 73-88

Żabiński Z., Systemy pieniężne na ziemiach polskich, Wrocław-Kraków 1981

Żuraszek-Ryś I., Inwentarze skarbca katedry ormiańskiej we Lwowie z XVIII wieku jako źródło do leksykologii historycznej, „Acta Universitatis Lodziensis. Folia Linguistica" 49, 2015, s. 115-124

Дашкевич Я. Р., Армянские колонии на Украине в источниках и литературе XVХІХ веков, Ереван 1962

Григорян В. Р., История армянских колоний Украины и Польши: Армяне в Подолии, Ереван 2005 (reprint wydania z 1980)

Лозинський Р., Етнічний склад населення Львова (у контексті суспільного розвитку Галичини), Львів 2005

\section{Netografia}

Dominik Bohdanowicz, [online], http://www.wiki.ormianie.pl/index.php?title=Dominik Bohdanowicz

Papée F., Historia miasta Lwowa w zarysie, Lwów 1924, [online], http://www.lwow.com. $\mathrm{pl} /$ historia/papee.html

Słownik języka polskiego, PWN, [online], sjp.pwn.pl

Stownik staropolski, [online], pl.wikisource.org/wiki/M._Arcta_S\%C5\%82ownik_Staro polski

Smirnow J., Szwedzi we Lwowie, [online], http://kuriergalicyjski.com/index.php/201202-03-12-29-43/irp/2184-szwedzi-we-lwowie-cz-i

Zięba A. A., Krzysztof Bernatowic, [online], http://www.wiki.ormianie.pl/index.php?title $=$ Krzysztof_Bernatowic

Zięba A. A., Zachariasz Gamocki, [online], http://www.wiki.ormianie.pl/index.php?title =Zachariasz_Gamocki 
Церква Святого Хреста (Львів), [online], https://uk.wikipedia.org/wiki/Церква_Свя того_Хреста_(Львів).

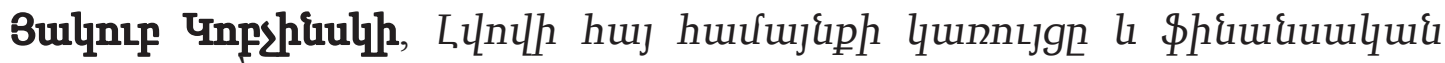

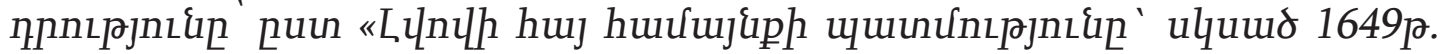
uhirl 1713p.» ḋtinuqph (Ossolineum, hu. 1646/II)

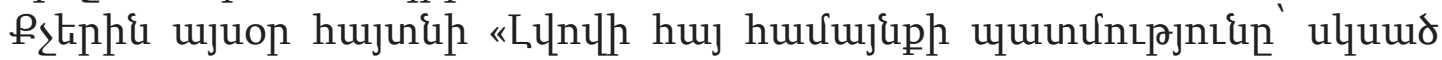

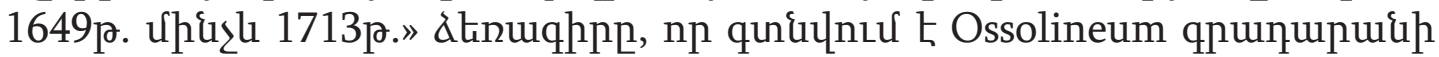

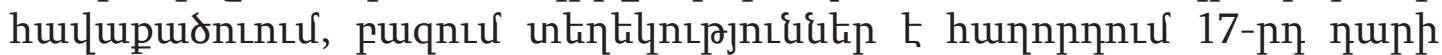

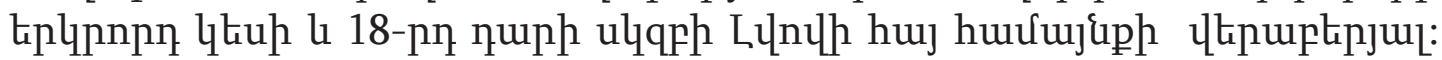

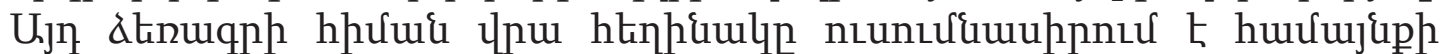

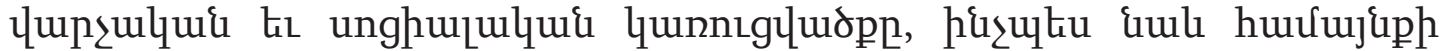

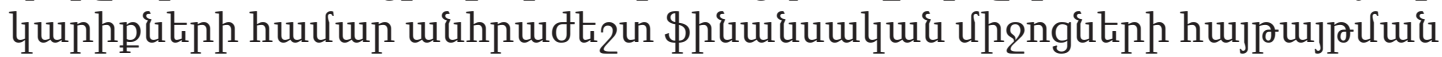

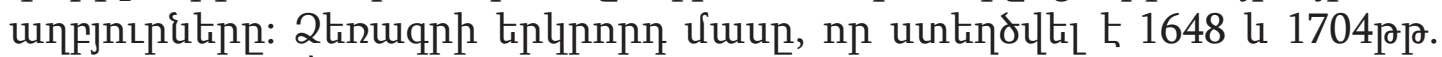

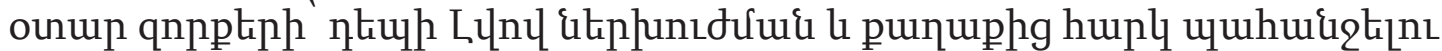

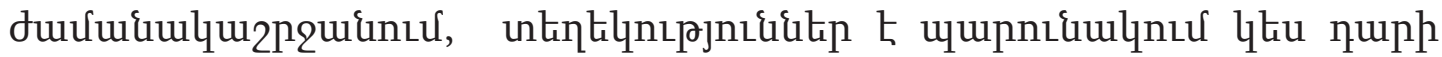

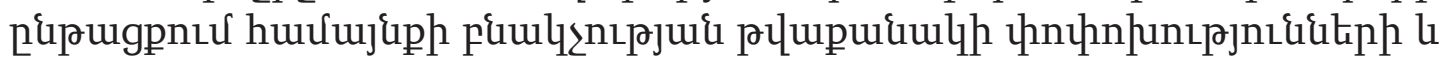

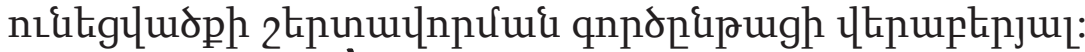

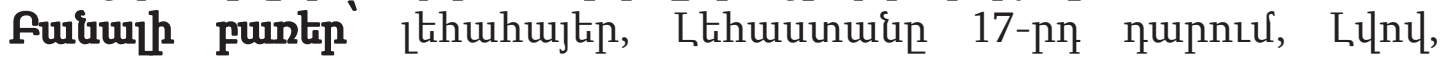

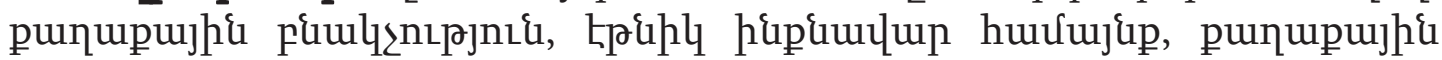

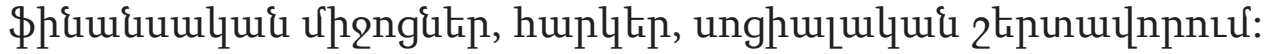

Jakub Kopczyński, The structure and the finances of the Armenian community in Lwów in the light of the "History of Lwów Armenians from 1649 until 1731" manuscript (Ossolineum no 1646/II)

The underexplored Polish-language manuscript entitled "The History of Lwów Armenians from 1649 until 1713", which is a part of the collections of the Ossolineum library, contains a great deal of information about the Armenian community in Lwów (now: Lviv) in the second half of the 17th century and at the beginning of the 18th century. On the basis of this source the author examines the administrative and social structure of the community as well as the way in which the requirements of this community were financed. Owing to the comprehensive registers featured in the second part of the manuscript, which were drawn up due to the imposition of contributions on Lwów by a foreign army in 1648 and 1704, the author also traces the changing number of the population and the estate-related stratification of the community in the period of about half a century.

Keywords: Polish Armenians, Poland of the 17th century, Lwów, burghers, ethnic self-government community, municipal finances, contribution, social stratification 


\section{Aneks 1. Rejestr koekwacji z 1653 roku}

\begin{tabular}{|c|c|c|}
\hline Osoba/osoby & \begin{tabular}{c|} 
Oszacowanie \\
majątku (zł)
\end{tabular} & Uwagi \\
\hline [Jan] Warteresowicz erespochan 2 & 600000 & dał \\
\hline $\begin{array}{l}\text { Iwaszko Torosowicz alias Wieniawski od } 25 \text { tys. y od } 100 \text { tys. } \\
\text { kreditu }\end{array}$ & 125000 & niedopłata \\
\hline Krzysztof J. Bernatowicz, reszty przy [Janie] Krzysztofowiczu & 80000 & dał \\
\hline Krzysztof Wartanowicz & 55000 & niedopłata \\
\hline Iwaszko Beznosy & 50000 & . \\
\hline Krzysztof Kasian & 40000 & dał \\
\hline Krzysztof Bernatowicz & 40000 & nadpłata \\
\hline Siroty Murada Eminowicza & 38000 & niedopłata \\
\hline Zachariaszowa Manczukiewicowa & 28000 & niedopłata \\
\hline Szymon Steckiewicz & 20000 & dał \\
\hline Owanesowa Copadyna & 20000 & niedopłata \\
\hline Zachariasza Kulcki córka & 18000 & niedopłata \\
\hline Awedik Bogdanowicz & 18000 & niedopłata \\
\hline Mikołay Steckiewicz & 17000 & nadpłata \\
\hline Krzysztof Zadikowicz & 16000 & niedopłata \\
\hline Zachariasz Jędrzeiowicz Pasternak & 15000 & niedopłata \\
\hline Jakub Wartanowicz & 14000 & niedopłata \\
\hline Łazarz Krzysztofowicz & 14000 & niedopłata \\
\hline Torossowa Gogtebowa & 13000 & niedopłata \\
\hline Grzegorz Der Łukaszewicz z Łukaszewicza zięciem & 12000 & dał \\
\hline Monika Łazarowicz & 12000 & niedopłata \\
\hline Krzysztof Der Zakariowicz & 12000 & niedopłata \\
\hline Zachariasz Derłyskiewicz z bratem & 9000 & niedopłata \\
\hline Sahak Wartanowicz & 9000 & nadpłata \\
\hline Krzysztof Minasczyk & 9000 & . \\
\hline Mikołay Wartanowicz & 8500 & nadpłata \\
\hline Łazar Der Torosowicz z matką & 8000 & niedopłata \\
\hline Jędrzey Tebinka & 8000 & niedopłata \\
\hline Jakubkowna y drudzy wzglendem kamienicy & 8000 & niedopłata \\
\hline Krzysztof Torosowicz & 8000 & nie dał \\
\hline Awedik Dersymonowicz & 8000 & . \\
\hline Mikołay Domażyrski & 7000 & dał \\
\hline Zachariaszowa Bernatowicowa & 7000 & niedopłata \\
\hline Jan Haftarz & 7000 & niedopłata \\
\hline Siroty Łupni Torossa & 7000 & niedopłata \\
\hline Krzysztof Hadziowski & 7000 & niedopłata \\
\hline Grzesko Hodzikiewicz & 7000 & niedopłata \\
\hline
\end{tabular}




\begin{tabular}{|c|c|c|}
\hline Osoba/osoby & $\begin{array}{l}\text { Oszacowanie } \\
\text { majątku (zł) }\end{array}$ & Uwagi \\
\hline Awedik Hadziczyk & 6000 & niedopłata \\
\hline Rospopowa y drudzy wzglendem kamienicy & 6000 & nie dał \\
\hline Jan Juchnowicz & 6000 & nadpłata \\
\hline Grzeskowa Mahmatowa & 6000 & nie dał \\
\hline Grzegorz Łyskiewicz & 6000 & niedopłata \\
\hline Toros Holubowicz & 6000 & niedopłata \\
\hline Awedik A. Bernatowicz & 6000 & nie dał \\
\hline Siroty Jendrzeia Łazarowica & 6000 & nadpłata \\
\hline $\begin{array}{l}\text { Iwaszkowa Stefanowicz 1500, } 4000 \text { wzglendem kamienicy } \\
\text { Rabiczkowskiej }\end{array}$ & 5500 & nie dał \\
\hline Krzysztof Kabachowski & 5500 & niedopłata \\
\hline Krzysztof Iwaszko Łyskiewicz & 5000 & dał \\
\hline Jakub Zadikowicz & 5000 & dat \\
\hline Krzysztofowa Parofowa & 5000 & nie dał \\
\hline Krzysztof Madziar & 5000 & . \\
\hline Mikołay Kieremowicz z małżonką & 4500 & nie dał \\
\hline Siroty Mikołaia Pałki 1500, wzglendem kamienicy 3000 & 4500 & nie dał \\
\hline Mikołay Derszymonowicz & 4500 & niedopłata \\
\hline Grzeskowa Tebenczyna & 4000 & niedopłata \\
\hline Siroty Krzysztofa Kulki & 4000 & nadpłata \\
\hline Z kamienicy Awedikowskiey od succesorów & 4000 & nie dał \\
\hline Mikołaiowa Tyrdzelowa & 4000 & nie dał \\
\hline Łazar Matiasowicz & 3500 & niedopłata \\
\hline Kasper Der Kasprowicz & 3500 & niedopłata \\
\hline Krzysztof A. Zachnowicz erespochan 1 & 3000 & nie dał \\
\hline Krzysztof Piotrowicz & 3000 & nie dał \\
\hline Franciszek Cerzelik z kamienicy & 3000 & nie dał \\
\hline Łazar Mikołaiowicz & 3000 & niedopłata \\
\hline Awedik Torosowicz od czenści z kamienicy Muradowey & 3000 & niedopłata \\
\hline Krzysztof Zachneczko & 3000 & niedopłata \\
\hline Wzglendem kamienicy Cerepkowiczowey p. Gliński & 3000 & nie dał \\
\hline Iwaszkowa Bogdanowiczowa & 3000 & niedopłata \\
\hline Staniek wzglendem cząstki & 3000 & nie dał \\
\hline Haczko Torosowicz & 3000 & nie dał \\
\hline Mikołay Norsesowicz & 3000 & nie dał \\
\hline Thuman Zadikowicz & 3000 & . \\
\hline Syn Arakielow & 3000 & . \\
\hline $\begin{array}{l}\text { Aswadur z Kasprem Kostowicz wzglendem kamienicy } \\
\text { i kramu }\end{array}$ & 2500 & nie dał \\
\hline Mikołaiowa Piramowiczowa & 2500 & nadpłata \\
\hline Jędrzey Jędrzeiowic Pasternak & 2500 & nadpłata \\
\hline
\end{tabular}




\begin{tabular}{|c|c|c|}
\hline Osoba/osoby & $\begin{array}{c}\text { Oszacowanie } \\
\text { majątku (zł) }\end{array}$ & Uwagi \\
\hline Mikołaiowa Warteresowicz & 2500 & nie dał \\
\hline Krzysztof Juskiewicz & 2500 & nadpłata \\
\hline Krzysztof Dudczyna & 2125 & niedopłata \\
\hline Tumanowiczówna z kamienicy & 2000 & nie dał \\
\hline Jerzy Patka & 2000 & nie dał \\
\hline Grzeska Norsesowica & 2000 & nie dał \\
\hline Grzegorz Ochasiewicz & 2000 & dał \\
\hline Krzysztof Kaprusiewicz & 2000 & nie dał \\
\hline Mikołaiowa Pałkowa & 2000 & nadpłata \\
\hline Sloska & 2000 & nie dał \\
\hline Donowak Bogdanowicz & 2000 & nie dał \\
\hline Zachariasz Hołubowicz Bazarczyk & 2000 & nie dał \\
\hline Toros Hazar & 2000 & niedopłata \\
\hline Wzglendem czonstek Krzysztofa po Kaski Hazar & 2000 & nie dał \\
\hline Sefer Stromey & 2000 & niedopłata \\
\hline Stefanowa wdowa wzglendem części & 2000 & nie dał \\
\hline Siroty Szunikowskie & 2000 & nie dał \\
\hline Iwaszkowa Kaprusiowa z zięciem & 2000 & niedopłata \\
\hline Grzeskowa Jezuicina & 2000 & nie dał \\
\hline Mikołay Haszczynski & 1500 & nie dał \\
\hline Spucha Derszymonowicz & 1500 & nie dał \\
\hline Gabriel Bartosowicz & 1500 & nadpłata \\
\hline Iwaszko Filipowicz wzglendem cząstki & 1500 & nie dał \\
\hline Kirkorowa wzglendem kramów dwóch & 1500 & nie dał \\
\hline Torosowa Szkotowa & 1500 & niedopłata \\
\hline Krzysztofa Awedikowica & 1500 & dał \\
\hline Krzysztof Kassian Bochdanowicz & 1500 & niedopłata \\
\hline Synowiec Polibowskiego wzglendem cząstki & 1500 & niedopłata \\
\hline Grzesko Łubnia & 1500 & niedopłata \\
\hline Awedikowa Łupniowa & 1500 & nie dał \\
\hline Wzglendem części na kamienicy Kotorskiey & 1500 & nie dał \\
\hline Nigoł Baydutowicz & 1500 & . \\
\hline Kasper Kalwin & 1500 & . \\
\hline Mikołay Flak & 1500 & . \\
\hline Jan Bernat Bernatowicz & 1200 & . \\
\hline Bochoc Owanowicz & 1000 & niedopłata \\
\hline Zachariaszowa Kopcowa z synem & 1000 & niedopłata \\
\hline Od syna Holuba Awedikowica wzglendem kramu bogatego & 1000 & nie dał \\
\hline Kirkor Abramowicz & 1000 & nie dał \\
\hline Stefan Laskowski od tysiąca wzglendem cząstki & 1000 & nie dał \\
\hline Linosowa Krzysztofowa & 1000 & nie dał \\
\hline
\end{tabular}




\begin{tabular}{|l|c|l|}
\hline \multicolumn{1}{|c|}{ Osoba/osoby } & $\begin{array}{c}\text { Oszacowanie } \\
\text { majątku (zł) }\end{array}$ & \multicolumn{1}{|c|}{ Uwagi } \\
\hline Łazar Dawidowicz Dynda & 1000 & nie dał \\
\hline Pisarz Iwaszkowicz & 1000 & . \\
\hline Zachariasz złotnik & 1000 & nie dał \\
\hline Córka Mahmaczykowej & 1000 & nie dał \\
\hline Bochdanowa wdowa & 1000 & nie dał \\
\hline Jędrzey Zachariasiewicz & 1000 & nie dał \\
\hline Siroty Patryarowe & 1000 & dał \\
\hline Jędrzey Kirkorowicz & 1000 & nie dał \\
\hline Aswadur & 1000 & niedopłata \\
\hline Iwaszko Izunik & 1000 & nie dał \\
\hline Awedik Chodzigiewicz & 1000 & . \\
\hline Iwaszko Plaskun & 1000 & . \\
\hline Zachariasz Haczeresowicz & 600 & nie dał \\
\hline Antonowa Kopczykowa & 600 & dał \\
\hline Siroty Harburaszowi & 600 & nie dał \\
\hline Ohanowa & 600 & nie dał \\
\hline Krzysztof Kaprusiewicz & 500 & nie dał \\
\hline Kazy. z panem Muradowiczem & 500 & . \\
\hline Wasil tłumacz & 500 & nie dał \\
\hline Łazar Atabowicz & 500 & niedopłata \\
\hline Jakub Łupnik & 500 & nie dał \\
\hline Balsamowa & 500 & . \\
\hline Szymon Haragioz & 500 & . \\
\hline Mikołay Zadikowicz & 500 & . \\
\hline Mikołaiowa Hazarowicz & 300 & nadpłata \\
\hline Mikołaiowa Bernatowiczowa & 300 & dał \\
\hline Janowa Moskiefka & 1624625 & \\
\hline SUMA & & \\
\hline & & \\
\hline
\end{tabular}

Źródło: „Dzieje Ormian lwowskich od r. 1649 - aż do r. 1713”, s. 156-165 


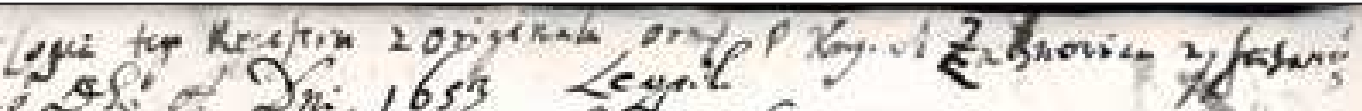
a

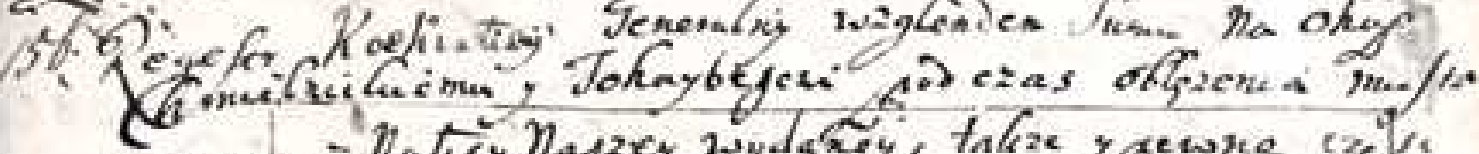

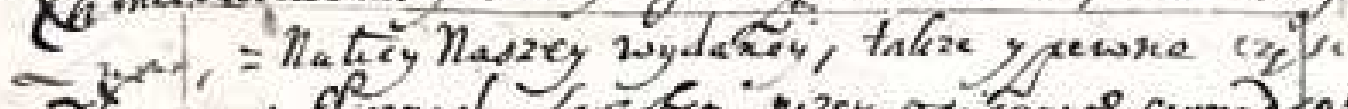

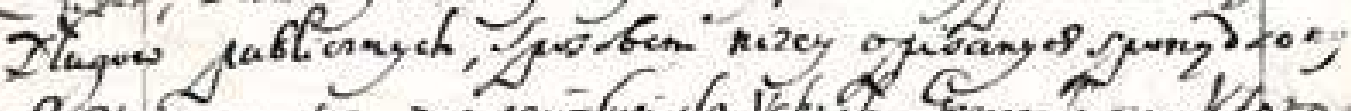

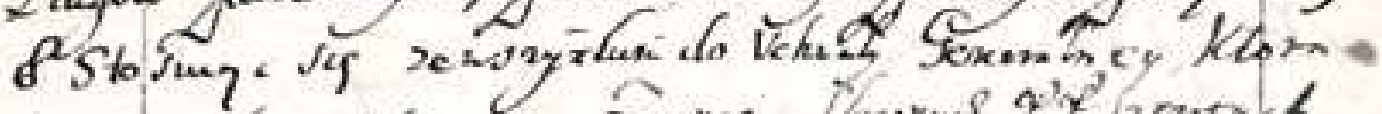

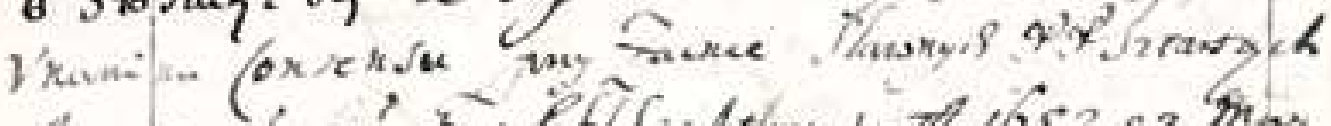

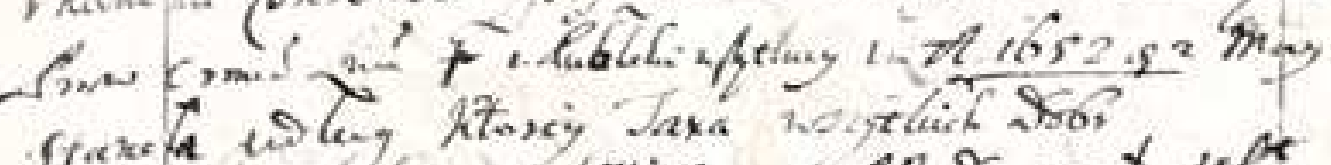

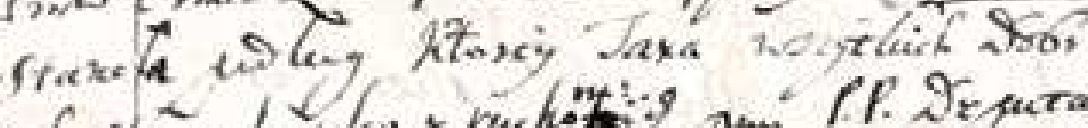

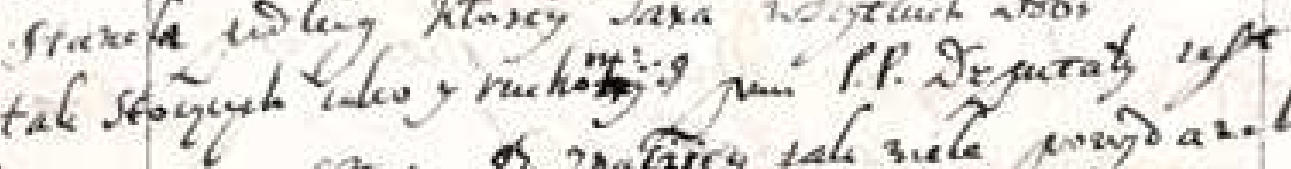

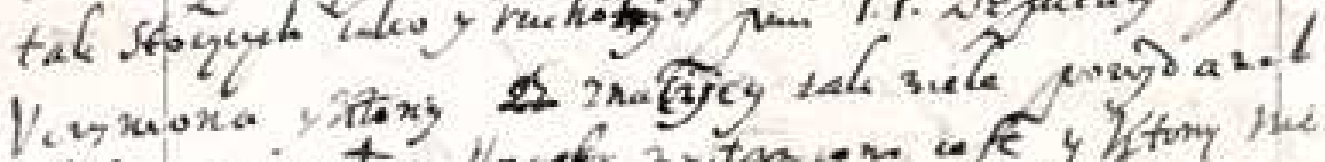

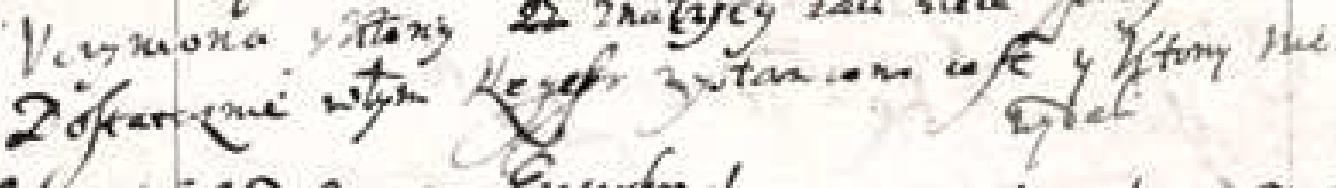

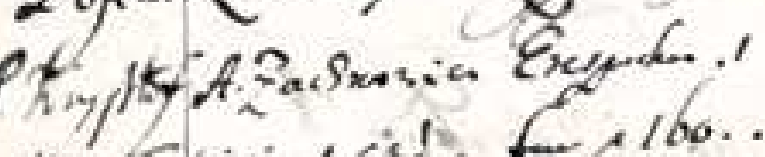

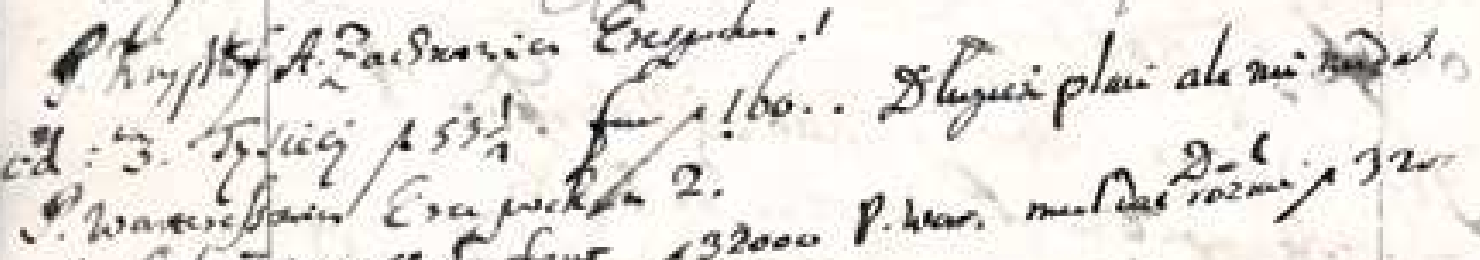

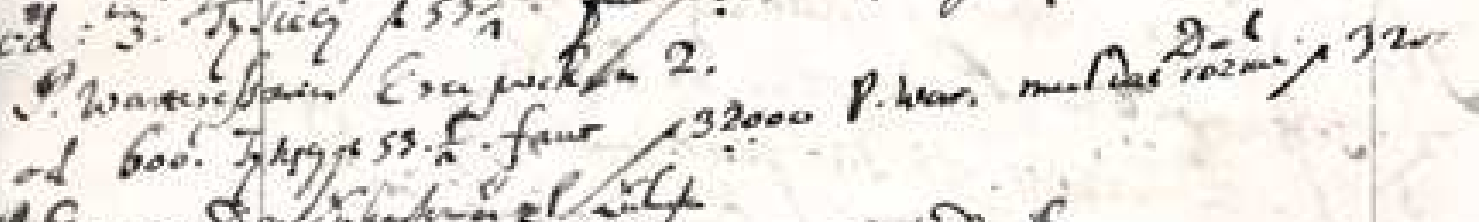

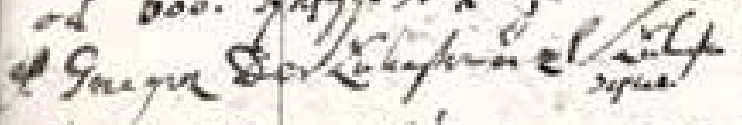

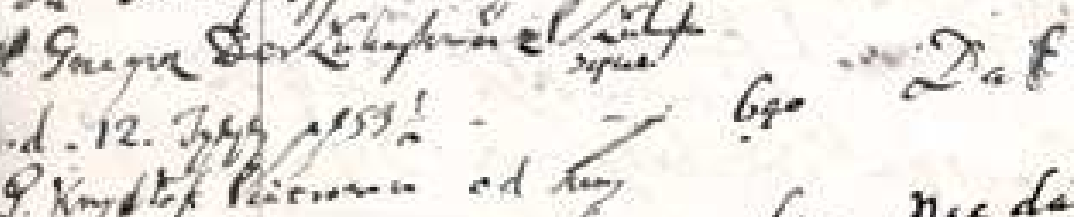

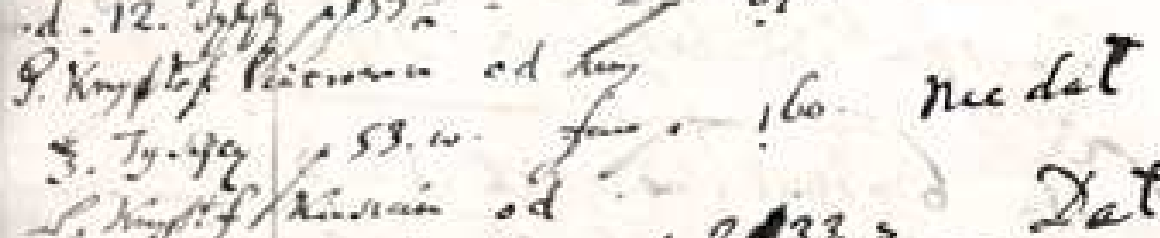

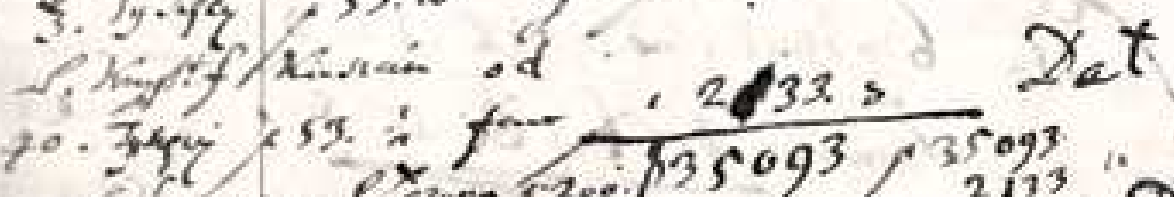

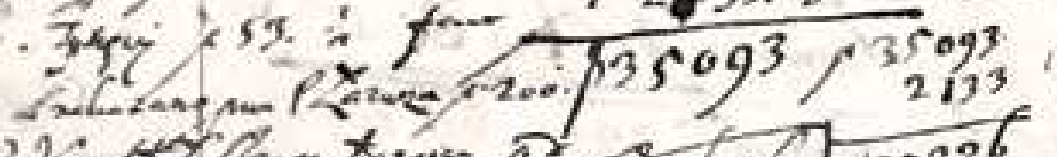

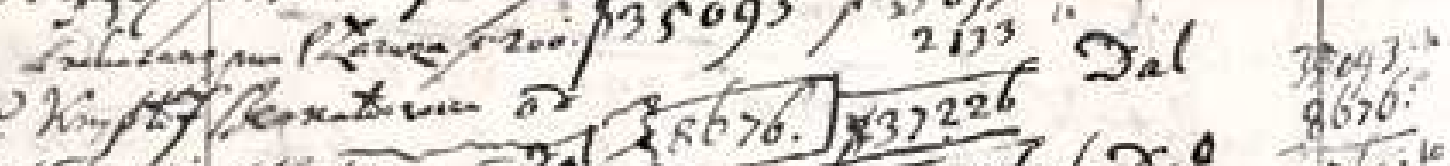

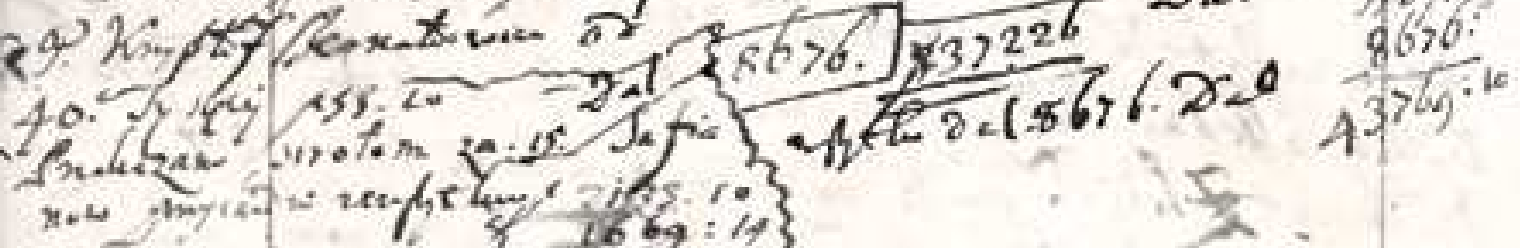

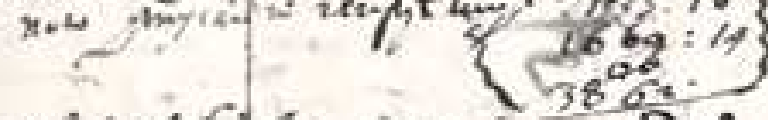

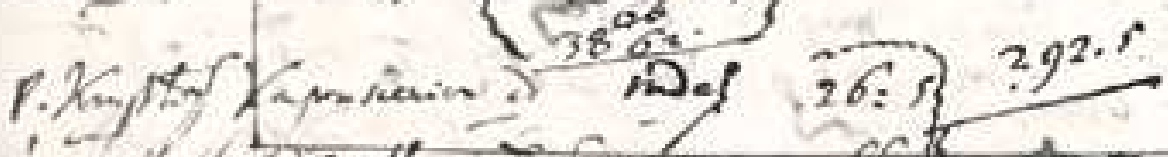

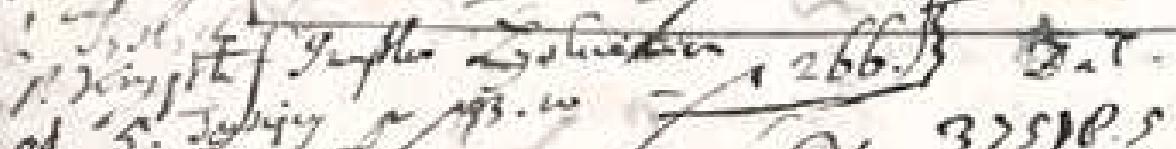

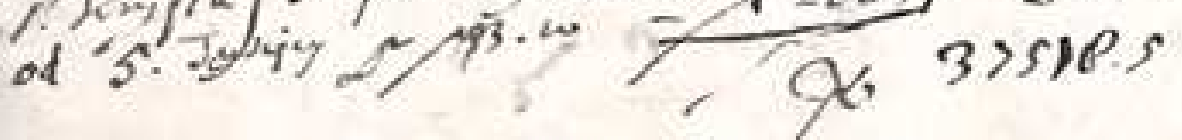

1. Pierwsza strona rejestru koekwacji z 1653 roku (s. 156 rękopisu) 
Aneks 2. Ormianie płacący na okup dla Szwedów w 1704 roku

\begin{tabular}{|c|c|c|}
\hline Osoba/osoby & $\begin{array}{l}\text { Kwota do zapła- } \\
\text { ty (talary bite) }\end{array}$ & $\begin{array}{l}\text { Kwota zapłaco- } \\
\text { na (talary bite) }\end{array}$ \\
\hline Dominik Bogdanowicz S.O.L. y D[irector] & 7000 & 7000 \\
\hline Łazarz Steckiewicz S.O.L. & 3000 & 3000 \\
\hline Gabrielowicz Piotr alias Petrik & 1000 & 1000 \\
\hline Stefanowicz Augustyn sukiennik & 1000 & 1000 \\
\hline Szymunowicowa & 1000 & \\
\hline Kahna wdowa & 800 & 800 \\
\hline Mikołay Wartanowicz & 500 & 400 \\
\hline Jan Teodor Jaskiewicz & 500 & 400 \\
\hline Gabriel Bogdanowicz ślepy & 400 & 400 \\
\hline Bogdan Latinowicz stary & 400 & 400 \\
\hline Mikołay Manczukiewicz stary S.O.L. & 300 & 300 \\
\hline [Jakub] Minassewicz stary S.L.O. & 300 & 300 \\
\hline Mikołay Hadziesowicz S.O.L. & 300 & 300 \\
\hline Norses Mowsesowicz & 300 & 300 \\
\hline Stefan Derwaszkiewicz S.O.L. & 250 & 250 \\
\hline Głowacki & 200 & . \\
\hline Pirumowicz Jakub S.O.L. & 200 & 200 \\
\hline Krzysztof Arakiełowicz & 200 & 200 \\
\hline Eliasowicz & 200 & . \\
\hline Haleprzski & 200 & . \\
\hline Minassewicz młody & 200 & 200 \\
\hline Jan Manczukiewic zięć iey [Kahny] & 200 & 200 \\
\hline Bogdan Faruchowicz & 200 & 200 \\
\hline Krzysztof Steckiewicz S.O.L. & 200 & 200 \\
\hline Bogdan Deriakubowicz zięć & 200 & 200 \\
\hline Gabriel Awedikowicz & 200 & 200 \\
\hline Derszymunowicz Szymun & 150 & 150 \\
\hline Teodor Jaskiewicz & 150 & 150 \\
\hline Wakuski & 150 & . \\
\hline Hołub Balsamowicz & 120 & 120 \\
\hline Gurnowilowa bo samego nie było & 100 & 100 \\
\hline Aniołkowa & 100 & 100 \\
\hline Grzegorz Piotrowicz & 100 & 100 \\
\hline Stefan Bogdanowicz zięć Nikoro[wicza]. & 100 & 100 \\
\hline Abram Donigiewicz & 100 & 100 \\
\hline Grzegorz Bernatowicz S.O. & 100 & 100 \\
\hline Krzysztof Deriakubowicz & 100 & 100 \\
\hline Thomasz Jaskiewicz & 100 & 100 \\
\hline Antoni Derbedrosowicz z synem & 100 & 100 \\
\hline
\end{tabular}




\begin{tabular}{|c|c|c|}
\hline Osoba/osoby & $\begin{array}{l}\text { Kwota do zapła- } \\
\text { ty (talary bite) }\end{array}$ & $\begin{array}{l}\text { Kwota zapłaco } \\
\text { na (talary bite) }\end{array}$ \\
\hline Samuelowicz łucznik Jan & 100 & 100 \\
\hline Stefan Ł. Steckiewicz & 100 & 100 \\
\hline Michał Arakielowicz zięć iego [S. Steckiewicza] & 100 & 100 \\
\hline Zachariasz Bernatowicz S.O.L. & 100 & 100 \\
\hline Juzef Juskiewicz & 100 & 100 \\
\hline Zadikiewicowa Zachn. & 100 & 100 \\
\hline Thomasz Jaskiewicz [drugi raz] & 100 & . \\
\hline Jakub Muradowicz & 100 & 100 \\
\hline Arutunowa & 60 & 100 \\
\hline Zachar[iasz] Bogdanowicz & 60 & 60 \\
\hline Juzef Steckiewicz & 50 & . \\
\hline Stefanowa Łyskiewiczowa wdowa & 50 & 50 \\
\hline Pepowa Kirkorowiczowa & 50 & 50 \\
\hline Kieremowiczowa wdo[wa] & 50 & 50 \\
\hline Jędrzey Derwaszkiewicz & 50 & [50] \\
\hline Krzysztof Bernatowicz & 50 & . \\
\hline Successorowie Krzysz[tofa] L. Augustyno[wicza] & 50 & 50 \\
\hline Teodor Torosewicz & 40 & 40 \\
\hline Jakub Krzysztofowicz & 30 & 30 \\
\hline Kassian & 30 & 30 \\
\hline Hołubówny sieroty & 30 & 30 \\
\hline Mikołay Rabiczka & 30 & 30 \\
\hline Milkon złotnik & 30 & 30 \\
\hline Bedrossowicz ubo[gi] & 20 & 20 \\
\hline Pruzowa & 20 & . \\
\hline Tatułowicz & 20 & 20 \\
\hline Szymun Wartanowicz nihil & 20 & {$[20]$} \\
\hline Mikołay Zadikiewicz mło[dy] & 20 & 20 \\
\hline Krzysztofowa Ł. Augustynowiczowa wdowa & 10 & 20 \\
\hline Krzysztof Aradzia & 10 & 10 \\
\hline Ormianka komornica & 10 & . \\
\hline Balcer Borszczowski & 10 & 10 \\
\hline Jan Steckiewicz S.O.L. & 10 & 10 \\
\hline Juhna Augustynowa & 10 & {$[10]$} \\
\hline Zieleńska & 10 & [10] \\
\hline Teodor Bernatowicz & 10 & 10 \\
\hline Bogdanówny & 10 & 10 \\
\hline Łukasiewicz & 10 & . \\
\hline Mikołay złotnik ze szpi. & 5 & {$[5]$} \\
\hline Stefanowa Augustynowiczowa Saba & 5 & 5 \\
\hline Zachariasz Głuszkiewicz ubogi & 2 & 2 \\
\hline
\end{tabular}




\begin{tabular}{|l|c|c|}
\hline \multicolumn{1}{|c|}{ Osoba/osoby } & $\begin{array}{c}\text { Kwota do zapła- } \\
\text { ty (talary bite) }\end{array}$ & $\begin{array}{c}\text { Kwota zapłaco- } \\
\text { na (talary bite) }\end{array}$ \\
\hline Derszymonowicz parzyciel &. & {$[10]$} \\
\hline Jakub Mathiaszewicz syn iey [Teodorowej] &. & 1000 \\
\hline Teodorowa wdowa Matyas. S.O.L. &. & 500 \\
\hline Manczukiewicowa Szy. S.O.L. &. & 200 \\
\hline Krzysztof Augustynowicz S.O.L. &. & 200 \\
\hline Krzysztof Juskiewicz &. & 200 \\
\hline Szymun Nikorowicz &. & 60 \\
\hline Grzegorz Augustynowicz &. & 50 \\
\hline Mikołay Zahnowicz S.O.L. &. & 10 \\
\hline Szymun Kieremowicz &. & 5 \\
\hline SUMA & 22392 & 22382 \\
\hline
\end{tabular}

Źródło: „Dzieje Ormian lwowskich od r. 1649 - aż do r. 1713”, s. 185-191, 202-203 


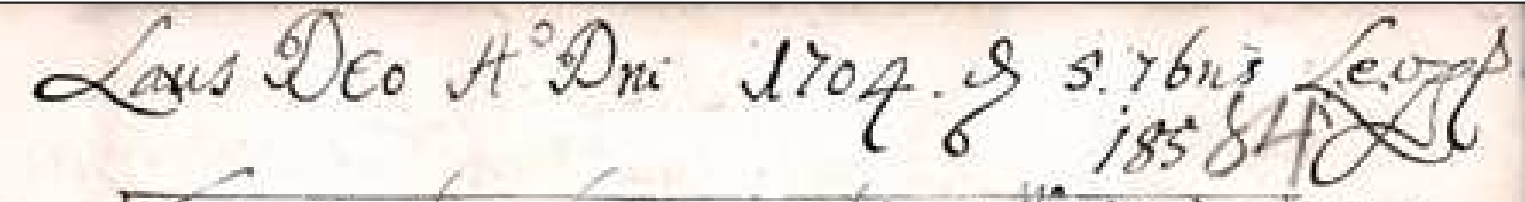

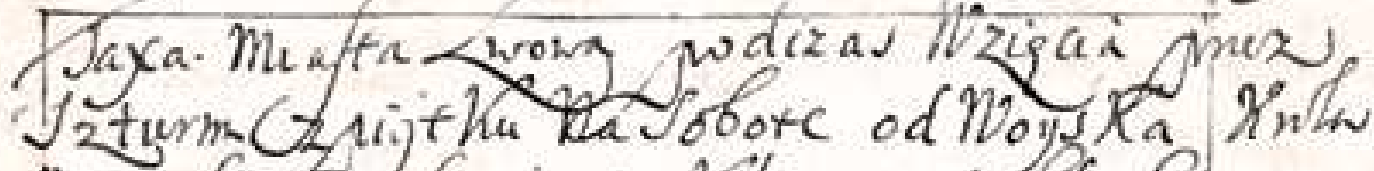

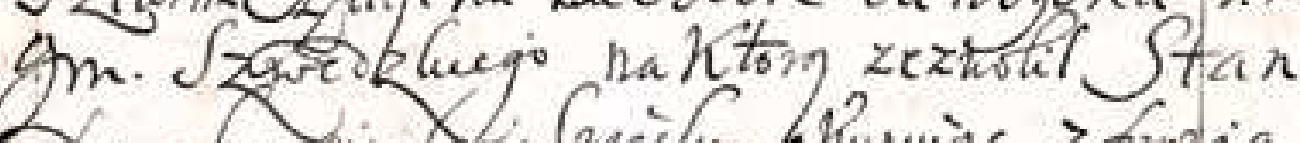

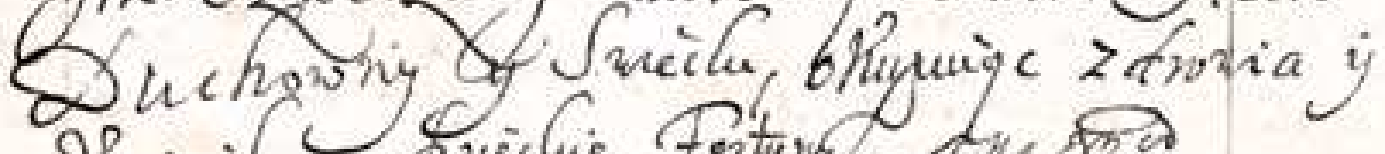

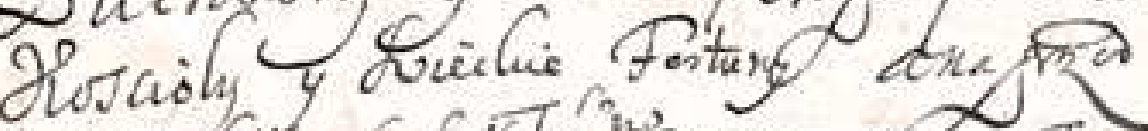

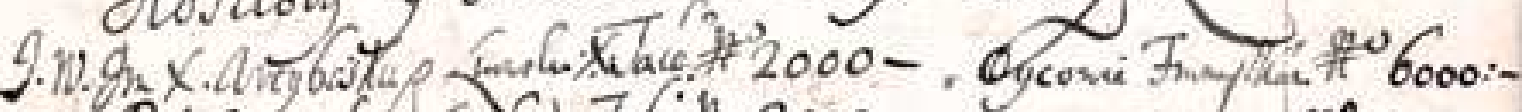

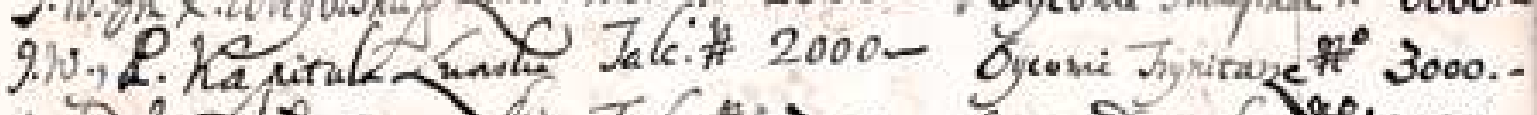

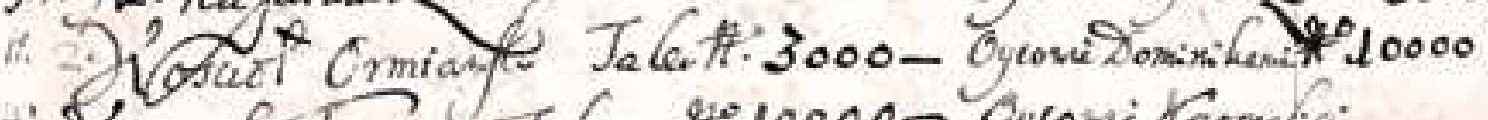

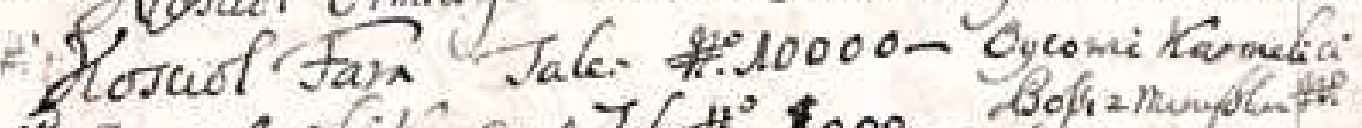

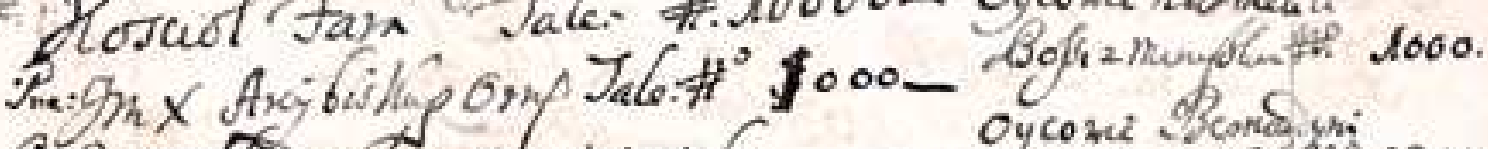

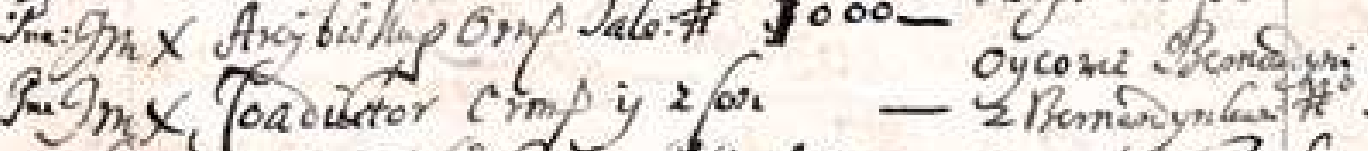

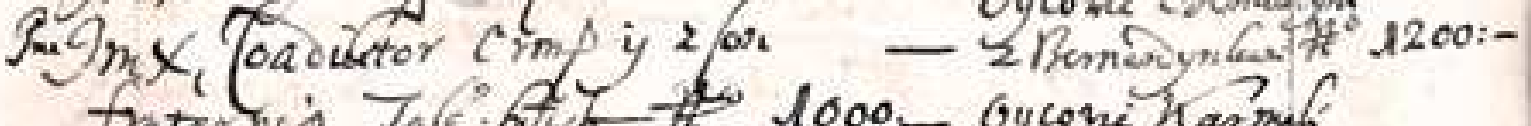

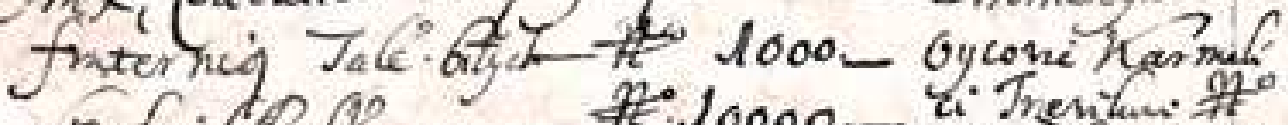

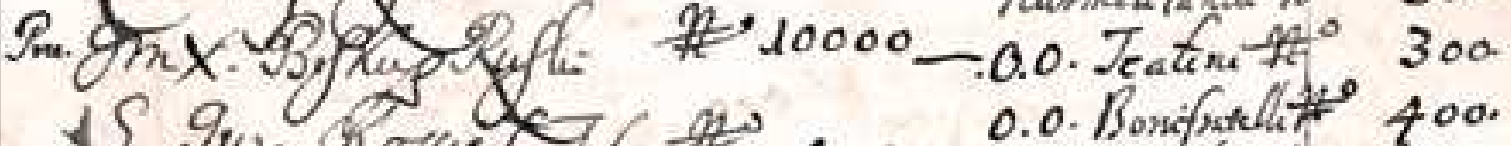

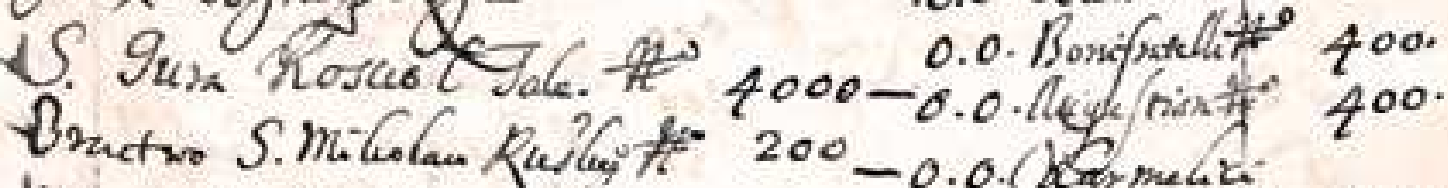

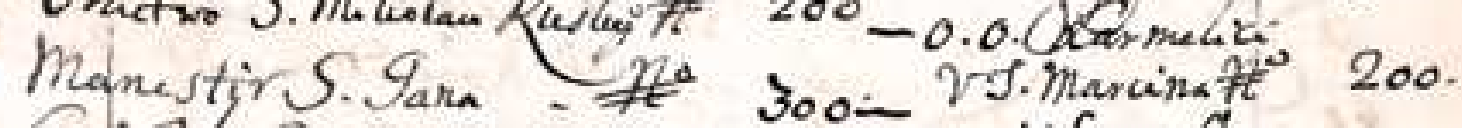

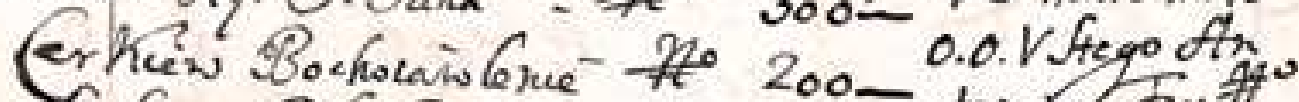

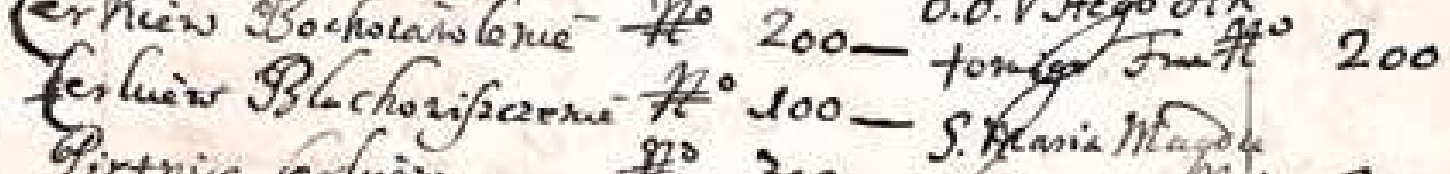

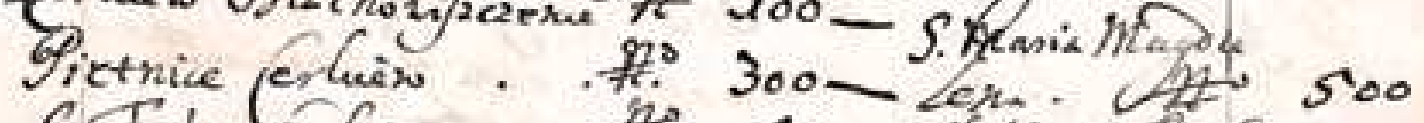

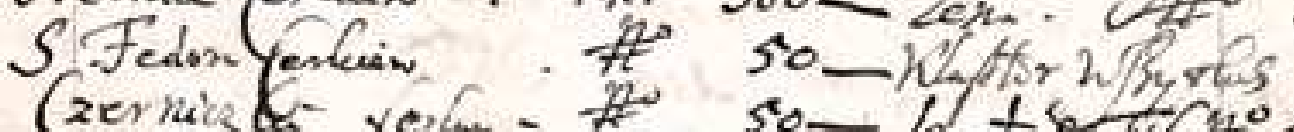

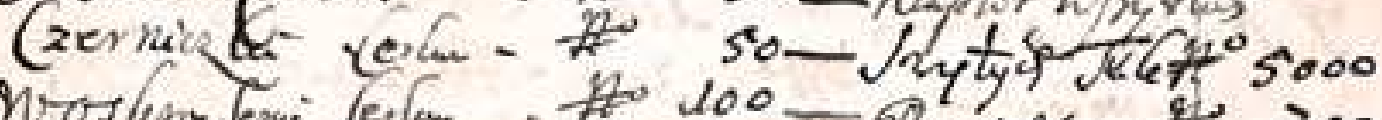

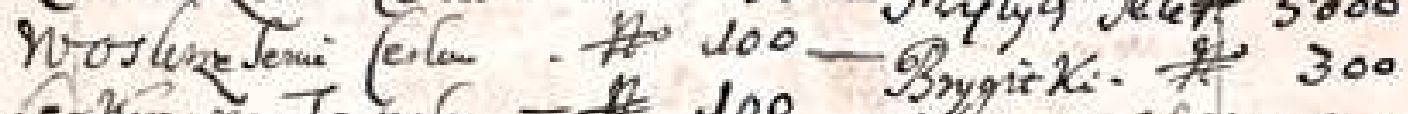

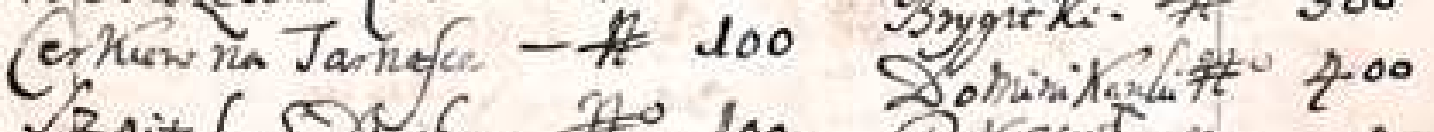

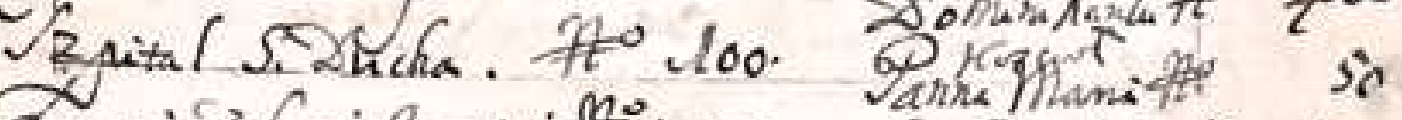

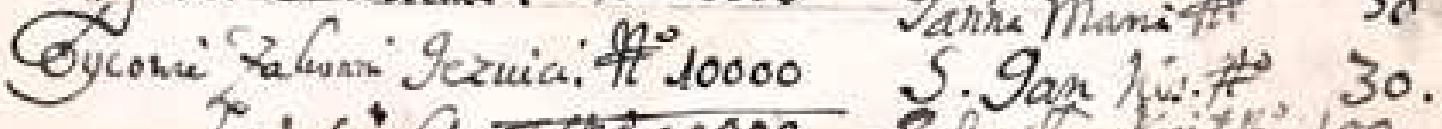

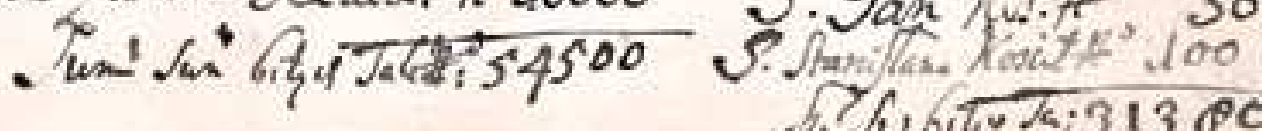

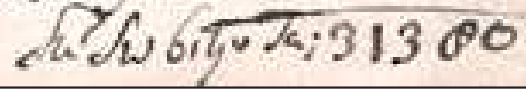

2. Pierwsza strona taksy ogólnomiejskiej z 1704 roku (s. 185 rękopisu) 